\title{
24. EOCENE-OLIGOCENE DIATOMS IN THE WESTERN INDIAN OCEAN: TAXONOMY, STRATIGRAPHY, AND PALEOECOLOGY 1
}

\author{
Juliane Fenner ${ }^{2}$ and Naja Mikkelsen ${ }^{3}$
}

\begin{abstract}
The occurrence of diatom species in the Eocene-Oligocene sections of Ocean Drilling Program (ODP) Leg 115 sites and Deep Sea Drilling Project (DSDP) Sites 219 and 236 in the low-latitude Indian Ocean are investigated. Diatoms are generally rare and poorly preserved in the Paleogene sequences we studied. The best-preserved assemblages are found close to ash layers in early Oligocene sediments.

The low-latitude diatom zonation established for the Atlantic region by Fenner in 1984 is fully applicable to the Paleogene sequences of the western Indian Ocean. Correlation of the diatom zones to the calcareous nannofossil stratigraphy of the sites places the Coscinodiscus excavatus Zone of Fenner within calcareous nannofossil Subzone CP16b.

For the Mascarene Plateau and the Chagos Ridge, the times when the sites studied, together with the areas upslope from them, subsided to below the euphotic zone are deduced from changes in the relative abundance between the group of benthic, shallow-water species and Grammatophora spp. vs. the group of fully planktonic diatom species.

The Eocene section of Site 707, on the Mascarene Plateau, is characterized by the occurrence of benthic diatoms (approximately $10 \%$ of the diatom assemblage). These allochthonous diatoms must have originated from shallow-water environments around volcanic islands that existed upslope from ODP Site 707 in Eocene times. In Oligocene and younger sediments of Sites 707 and 706, occurrences of benthic diatoms are rare and sporadic and interpreted as reworked from older sediments. This indicates that the area upslope from these two Mascarene Plateau sites had subsided below the euphotic zone by the early Oligocene. Only Grammatophora spp., for which a neritic but not benthic habitat is assumed, continues to be abundant throughout the Oligocene sequences.

The area of the Madingley Rise sites (Sites 709-710) and nearby shallower areas subsided below the euphotic zone already in middle Eocene times, as benthic diatoms are almost absent from these Eocene sections. Only sites located on abyssal plains, and which intermittently received turbidite sediments (e.g., Sites 708 and 711), contain occasionally single, benthic diatoms of Oligocene age.

The occurrence of the freshwater diatom Aulacosira granulata in a few samples of late early Oligocene and late Oligocene age at Sites 707, 709, and 714 is interpreted as windblown. Their presence indicates at least seasonally arid conditions for these periods in the source areas of eastern Africa and India.

Three new species and two new combinations are defined: Chaetoceros asymmetricus Fenner sp. nov.; Hemiaulus gracilis Fenner, sp. nov.; Kozloviella meniscosa Fenner, sp. nov.; Cestodiscus demergitus (Fenner) Fenner comb. nov.; and Rocella princeps (Jousé) Fenner comb. nov.
\end{abstract}

\section{INTRODUCTION}

Published information on Paleogene diatoms from the Indian Ocean is sparse. Poorly preserved diatoms from the Eocene to the early Oligocene were reported from eastern Indian Ocean DSDP Sites 216 and 217, on the northern extensions of the Ninetyeast Ridge, and from DSDP Site 220 on the Laccadive Ridge (Fenner, 1984b). During Leg 115, we recovered diatom-bearing sediments of Eocene-Oligocene age in eight of ten sites (Figs. 1 and 2). These sites were drilled along two northsouth transects in the western tropical-subtropical Indian Ocean. The sites cover a wide range of water depths (Table 1).

In this paper, we analyze the diatom assemblages from these sites in detail. Where preservation is sufficient, the diatoms are used for stratigraphic assignments and paleoecological interpretation. In addition, diatomaceous Paleogene sections from Sites 236 and 219 are also included in the present study.

\section{METHODS}

Samples from Leg 115 holes were processed by placing approximately $2-3 \mathrm{~g}$ of each sample in a $250-\mathrm{ml}$ beaker. Then, 25

1 Duncan, R. A., Backman, J., Peterson, L. C., et al., 1990. Proc. ODP, Sci. Results, 115: College Station, TX (Ocean Drilling Program).

2 Geologisch-Paläontologisches Institut der Universität Kiel, Olshausenstr. 40-60, D-2300 Kiel, Federal Republic of Germany. mark.

${ }^{3}$ Geological Survey of Denmark, Thoravej 8,2400 Copenhagen NV, Den- $\mathrm{ml}$ of $10 \%$ hydrochloric acid was added, and the sample gently heated until the liquid became light yellow. Treatment with $30 \%$ hydrogen peroxide was rarely required. The residue sample was washed by adding $200 \mathrm{ml}$ of distilled water three times. The liquid was decanted after $1 \frac{1}{2} \mathrm{hr}$. The decanting process was repeated three times. Smear slides were prepared by transferring the suspended material with a disposable pipette to a $22-\times 40$ mm cover slip, which was dried and mounted with Hyrax on 22$\times 75$-mm glass slides.

The sample processing method for the DSDP samples is given in Fenner (1984b).

The slides were scanned at a magnification of $1000 \times$ in Leitz Orthomat photomicroscopes with oil immersion objectives (PL Apo Oel 100/1.32). The relative abundances of diatoms and other noncalcareous microfossil groups in the $\mathrm{HCl}$-insoluble residue were recorded. Abundances are presented as in Fenner (in press): single $(\mathrm{S})=<0.1 \%$; rare $(\mathrm{R})=0.1 \%-1.0 \%$; frequent $(\mathrm{F})=1.0 \%-10.0 \%$; common $(\mathrm{C})=10.0 \%-30.0 \%$; abundant $(\mathrm{A})=30.0 \%-50.0 \%$; and dominant $(\mathrm{D})=>50.0 \%$. For these abundance estimates, a minimum of 300 valves were checked. However, diatom preservation was too poor in a number of samples to provide reliable abundance estimates. A complete list of all samples checked for presence/absence of diatoms is given in Table 2 .

Estimates of the diatom preservation were obtained by combining observations of the relative abundance of dissolution-resistant species as Grammatophora spp., Arachnoidiscus spp., Cocconeis spp., Hemiaulus exiguus, Paralia sulcata, and robust 


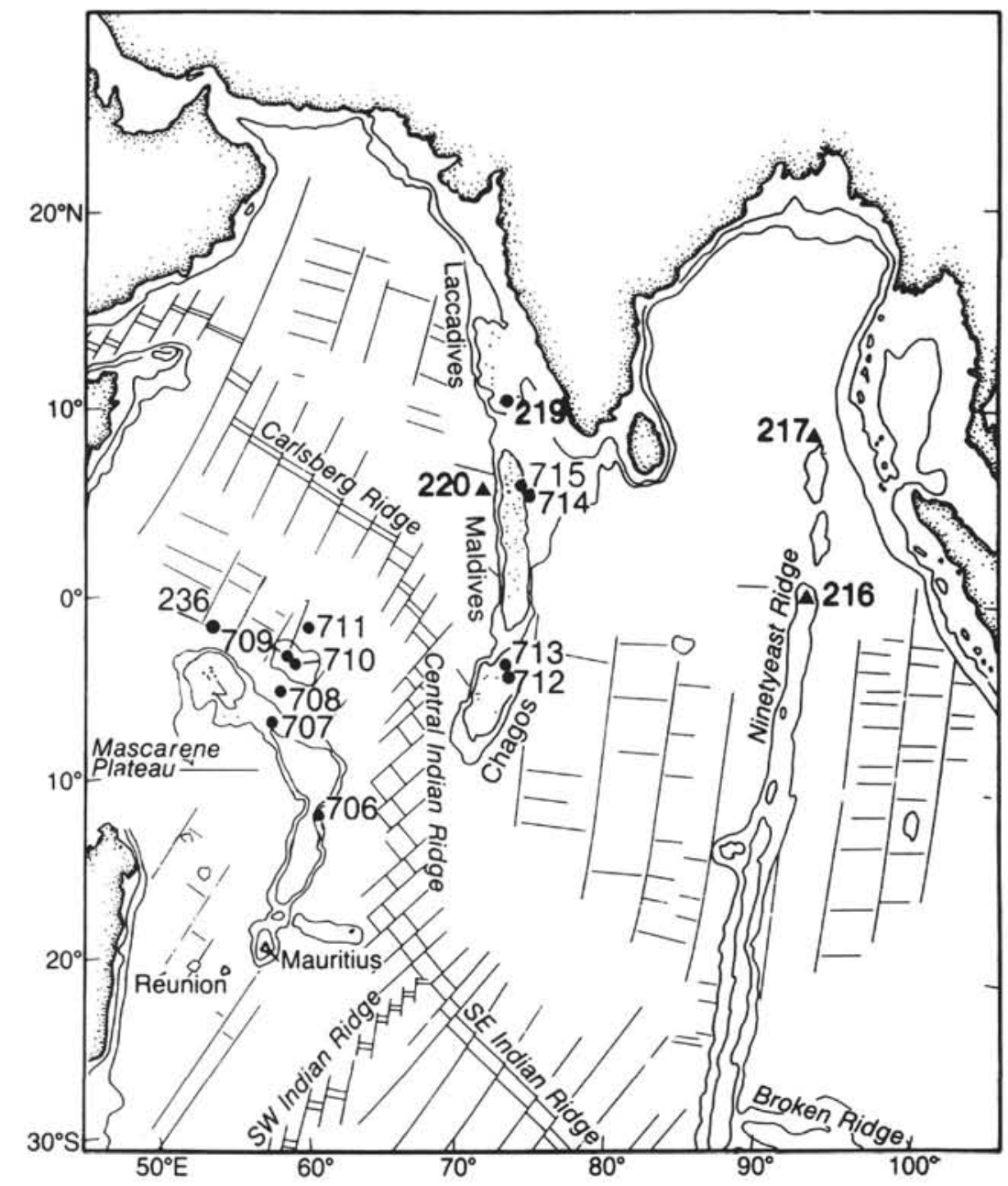

Figure 1. Regional setting and location of DSDP and ODP sites with Eocene-Oligocene diatomaceous sediments in the central Indian Ocean. Solid circles $=$ sites analyzed for this study; Solid triangles = sites analyzed by Fenner (1984b).

shallow-water species of the genus Triceratium with observations of the degree of fragmentation and etching of the diatom valves. The categories differentiated are poor $(\mathrm{P})$, moderate $(\mathrm{M})$, good $(\mathrm{G})$, and excellent $(\mathrm{E})$.

\section{RESULTS}

\section{Diatom Abundance and Preservation}

The occurrences of diatoms through the middle Eocene to late Oligocene sections of the Leg 115 sites and DSDP Sites 219 and 236 are given in Figure 2 and Table 2.

In sediments of early middle Eocene age, diatoms are generally rare and poorly preserved. Moderately well-preserved diatom assemblages were encountered only in Holes $707 \mathrm{C}$ and $713 \mathrm{~A}$ in the upper part of middle Eocene calcareous nannofossil Subzone CPl3c. In Hole 707C a total number of not more than 8-16 species per sample were found, and in Hole $713 \mathrm{~A}$ it was slightly more: 11-26 species per sample (Tables 3-5). In the late late Eocene sediments, diatom preservation improves. And in the Oligocene sections of sites around and from the ChagosMascarene Ridge system, an interval with well-preserved diatoms was recovered just below a series of ash layers occurring at the base of calcareous nannofossil Zone CPI8. In the younger part of all the recovered Oligocene sequences, diatom preservation again is poorer.

\section{Stratigraphy}

In the middle Eocene and early late Eocene sections studied from the Indian Ocean, diatom preservation is so poor that no assignments to the diatom zones of Fenner (1984a) are possible. The middle Eocene is characterized by the occurrence of Pseudopodosira spp., Craspedodiscus umbonatus, Abas wittii, Dextradonator eximius, and Strangulonema barbadense. The fairly dissolution-resistant Liostephania spp. is enriched in these poorly preserved assemblages.

The late Eocene Asterolampra marylandica and Baxteriopsis brunii Zones of Fenner (1984a) are identified in the studied sections, the base of the later zone by the first abundant appearance (FAAD) of $B$. brunii. Other species that occur consistently in these late Eocene assemblages include $\mathrm{A}$. marylandica, $\mathrm{He}$ miaulus subacutus, $H$. altar, and $H$. lyriformis (Fig. 3).

Correlation of the diatom FAADs with the calcareous nannofossil zones of Okada and Bukry (1980) determined for the Leg 115 sites by Okada (this volume) indicates that the early Oligocene Coscinodiscus excavatus Zone falls within Subzone CPI6b. The strong increase in the abundance of Cestodiscus spp. occurs in the lower part of the Cestodiscus reticulatus Zone and in nannofossil Zone CPI7 (Fig. 4). Whether the strong increase in Chaetoceros asymmetricus between 35.5 and $36 \mathrm{Ma}$ is of stratigraphic importance or is environmentally controlled cannot be decided from the present material. Nor does the wide 

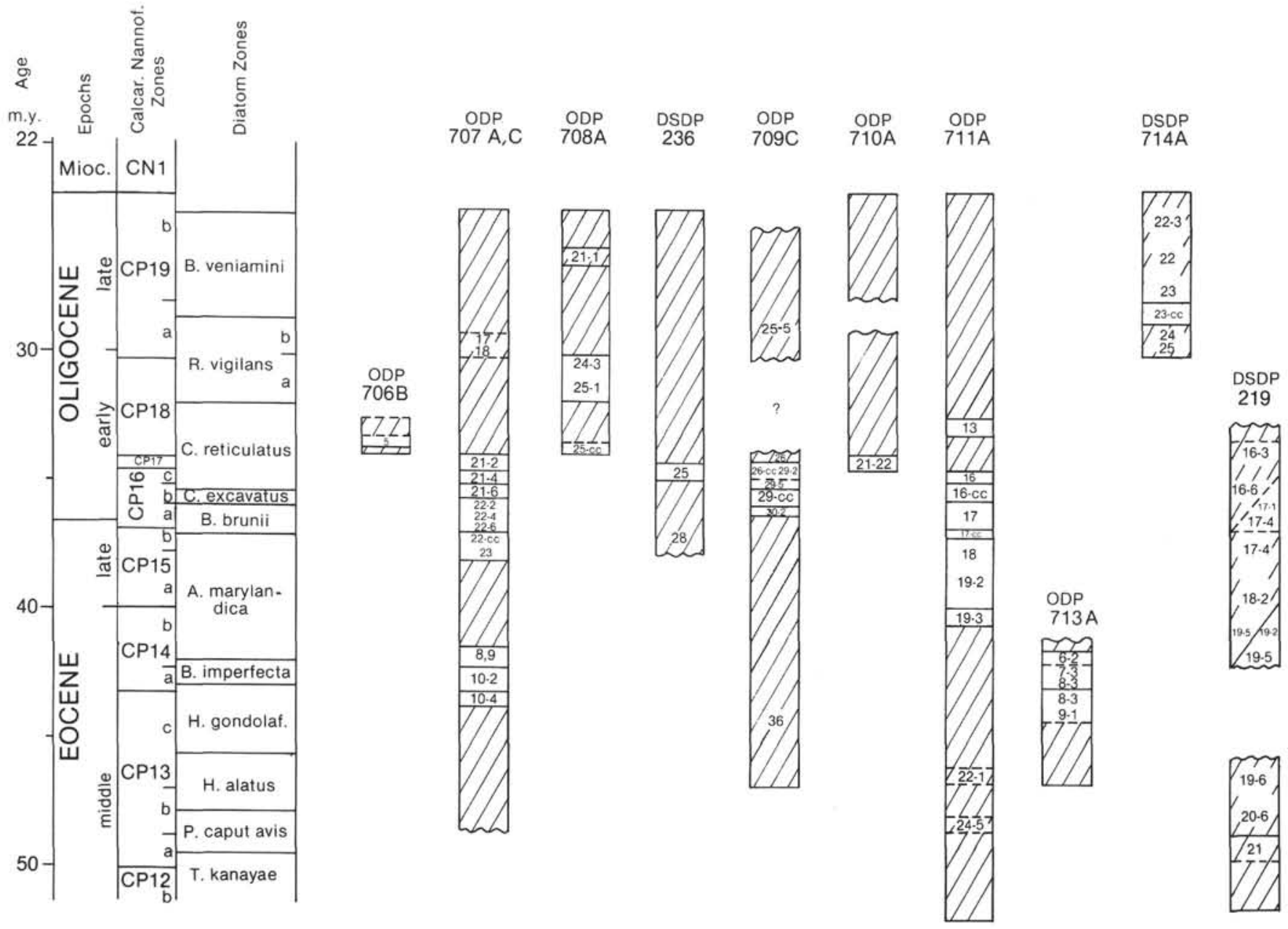

Figure 2. Summary of middle Eocene to late Oligocene diatom occurrences in the studied sites. The nannofossil zonation is of Okada and Bukry (1980) and the diatom zonation of Fenner (1984a). The Berggren et al. (1985) correlation of nannofossil zones against absolute time scale is used. Hatched intervals are barren of diatoms. In the marginally hatched intervals, diatoms are poorly preserved. The sites are arranged according to their latitudinal position north (right) to south (left).

Table 1. Location and water depth of studied Paleogene sections in DSDP and ODP sites of the western Indian Ocean.

\begin{tabular}{ccc}
\hline Hole & $\begin{array}{c}\text { Geographic position } \\
\text { (latitude, longitude) }\end{array}$ & $\begin{array}{c}\text { Water } \\
\text { depth (m) }\end{array}$ \\
\hline $706 \mathrm{~B}$ & $13^{\circ} 06.86^{\prime} \mathrm{S}, 61^{\circ} 22.27^{\prime} \mathrm{E}$ & 2507.5 \\
$707 \mathrm{~A}$ & $7^{\circ} 32.72^{\prime} \mathrm{S}, 59^{\circ} 01.00^{\prime} \mathrm{E}$ & 1541.4 \\
$707 \mathrm{C}$ & $7^{\circ} 32.73^{\prime} \mathrm{S}, 59^{\circ} 01.01^{\prime} \mathrm{E}$ & 1541.4 \\
$708 \mathrm{~A}$ & $5^{\circ} 27.23^{\prime} \mathrm{S}, 59^{\circ} 56.63^{\prime} \mathrm{E}$ & 4096.5 \\
$709 \mathrm{~B}, \mathrm{C}$ & $3^{\circ} 54.72^{\prime} \mathrm{S}, 60^{\circ} 33.16^{\prime} \mathrm{E}$ & 3038.2 \\
$710 \mathrm{~A}$ & $4^{\circ} 18.69^{\prime} \mathrm{S}, 60^{\circ} 48.76^{\prime} \mathrm{E}$ & 3812.0 \\
$711 \mathrm{~A}$ & $2^{\circ} 44.46^{\prime} \mathrm{S}, 61^{\circ} 09.75^{\prime} \mathrm{E}$ & 4428.2 \\
$712 \mathrm{~A}$ & $4^{\circ} 12.99^{\prime} \mathrm{S}, 73^{\circ} 24.38^{\prime} \mathrm{E}$ & 2892.4 \\
$713 \mathrm{~A}$ & $4^{\circ} 11.58^{\prime} \mathrm{S}, 73^{\circ} 23.65^{\prime} \mathrm{E}$ & 2909.5 \\
$714 \mathrm{~A}$ & $5^{\circ} 03.69^{\prime} \mathrm{N}, 73^{\circ} 46.98^{\prime} \mathrm{E}$ & 2231.5 \\
$715 \mathrm{~A}$ & $5^{\circ} 04.89^{\prime} \mathrm{N}, 73^{\circ} 49.88^{\prime} \mathrm{E}$ & 2269.3 \\
219 & $9^{\circ} 01.75^{\prime} \mathrm{N}, 72^{\circ} 52.67^{\prime} \mathrm{E}$ & 1764.0 \\
236 & $1^{\circ} 40.62^{\prime} \mathrm{S}, 57^{\circ} 38.85^{\prime} \mathrm{E}$ & 4487.0 \\
\hline
\end{tabular}

sample spacing allow a decision to be made whether the onset of dominance of $C$. asymmetricus is time transgressive or not.

The identification of the base of the early Oligocene Cestodiscus reticulatus Zone and its accurate stratigraphic position is doubtful because of an interval of poor opal-A preservation at the base of the zone. Thus, $C$. reticulatus could be missing there because of dissolution rather than evolution.

The early to late Oligocene Rocella vigilans Zone with common Synedra jouseana and the name-giving species is represented in Section 115-708A-24X-3, 118-119 cm, to 115-708A$25 \mathrm{X}-1,102-103 \mathrm{~cm}$. Part of the Bogorovia veniamini Zone with Rossiella symmetrica, Coscinodiscus rhombicus, and Lisitzinia ornata as additional stratigraphic marker species is present in Section 115-714A-22X-CC to 115-714A-23X-CC.

The sequence of first appearances of stratigraphically important diatom species in the Oligocene of the Indian Ocean and their stratigraphic distribution (Fig. 3) agrees well with the observations by Fenner (1984a) from the low-latitude Atlantic.

\section{Paleoecology}

The dominant planktonic diatoms in the Eocene and early Oligocene Leg 115 sequences are typical low- to mid-latitude species such as Hemiaulus altar, H. lyriformis, H. subacutus, Skeletonema barbadense, Chaetoceros asymmetricus, Cestodiscus gemmifer, C. reticulatus, C. parmula, and Coscinodiscus excavatus. In the late Oligocene assemblages, cosmopolitan species such as Synedra jouseana, Rocella vigilans, Coscinodiscus rhombicus, and Lisitzinia ornata become dominant. These observations agree with the paleogeographic reconstructions of 
Table 2. List of samples analyzed for presence/absence of diatoms. The abundance of diatoms is abbreviated as follows: present, +; fragments present but extremely rare and poorly preserved, (+); and absent, - .

\begin{tabular}{|c|c|c|c|}
\hline $\begin{array}{l}\text { Core, section, } \\
\text { interval }(\mathrm{cm})\end{array}$ & $\begin{array}{l}\text { Diatom } \\
\text { abundance }\end{array}$ & $\begin{array}{l}\text { Nannofossil } \\
\text { zone }\end{array}$ & $\begin{array}{l}\text { Diatom } \\
\text { zone }\end{array}$ \\
\hline \multicolumn{4}{|l|}{$115-706 \mathrm{~A}-$} \\
\hline $3 \mathrm{H}-1,52-53$ & - & CP18 & - \\
\hline $4 \mathrm{H}-\mathrm{CC}$ & - & CP18 & - \\
\hline $5 \mathrm{H}-\mathrm{CC}$ & - & CP18 & - \\
\hline $6 \mathrm{H}-\mathrm{CC}$ & - & CP18 & - \\
\hline \multicolumn{4}{|l|}{$115-706 \mathrm{~B}-$} \\
\hline $1 \mathrm{H}-\mathrm{CC}$ & - & CP18 & - \\
\hline $2 \mathrm{H}-\mathrm{CC}$ & - & CP18 & - \\
\hline $3 \mathrm{H}-\mathrm{CC}$ & - & CP18 & - \\
\hline $4 \mathrm{H}-\mathrm{CC}$ & - & CP18 & - \\
\hline $5 \mathrm{X}-\mathrm{CC}$ & $(+)$ & CP18 & C. reticulatus \\
\hline $6 \mathrm{X}-\mathrm{CC}$ & - & CP18 & - \\
\hline $7 \mathrm{X}-\mathrm{CC}$ & - & & \\
\hline \multicolumn{4}{|l|}{$115-707 \mathrm{~A}=$} \\
\hline $16 \mathrm{H}-2,105-106$ & - & CP19b & - \\
\hline $16 \mathrm{H}-4,105-106$ & - & CP19b & - \\
\hline $16 \mathrm{H}-6,105-106$ & - & CP19a & - \\
\hline $16 \mathrm{H}-\mathrm{CC}$ & - & CP19a & - \\
\hline $17 \mathrm{H}-\mathrm{CC}$ & + & CP19a & Oligocene \\
\hline $18 \mathrm{H}-\mathrm{CC}$ & $(+)$ & CP19a & Oligocene \\
\hline $19 \mathrm{H}-\mathrm{CC}$ & $(+)$ & CP18 & - \\
\hline $20 X-1,105-106$ & - & CP18 & - \\
\hline $20 X-3,105-106$ & - & CP17-CP16c & - \\
\hline $20 \mathrm{X}-\mathrm{CC}$ & - & CP17-CP16c & - \\
\hline $21 X-2,105-106$ & + & CP17-CP16c & C. reticulatus \\
\hline $21 X-4,105-106$ & + & CP17-CP16c & C. reticulatus \\
\hline $21 X-6,105-106$ & + & CP16ab & C. reticulatus \\
\hline $21 \mathrm{X}-\mathrm{CC}$ & - & CP16ab & - \\
\hline $22 X-2,105-106$ & $(+)$ & CP16ab & - \\
\hline $22 X-4,105-106$ & $(+)$ & CP16ab & - \\
\hline $22 X-6,105-106$ & $(+)$ & CP16ab & B. brunii \\
\hline $22 \mathrm{X}-\mathrm{CC}$ & + & CP15b & A. marylandica \\
\hline $23 X-2,105-106$ & $(+)$ & CP15b & A. marylandica \\
\hline $23 X-4,105-106$ & $(+)$ & CP15b & A. marylandica \\
\hline $23 X-6,105-106$ & - & CP15b & - \\
\hline $23 \mathrm{X}-\mathrm{CC}$ & - & CP15a & - \\
\hline \multicolumn{4}{|l|}{$115-707 \mathrm{C}$ - } \\
\hline $3 \mathrm{R}-2,110-111$ & $(+)$ & CP16a & early Oligocene \\
\hline $3 \mathrm{R}-4,110-111$ & $(+)$ & CP16a & B. brunii \\
\hline $3 \mathrm{R}-6,110-111$ & $(+)$ & CP16a & B. brunii \\
\hline 3R-CC & + & CP15b & B. brunii \\
\hline 5R-CC & - & CP15a & - \\
\hline 6R-CC & - & CP15a & - \\
\hline 7R-CC & - & $\mathrm{CP} 14 \mathrm{~b}$ & - \\
\hline 8R-CC & - & CP14b & - \\
\hline $9 \mathrm{R}-2,51-52$ & $(+)$ & CP14b & middle Eocene \\
\hline 9R-CC & + & CP14b & middle Eocene \\
\hline $10 \mathrm{R}-2,110-111$ & + & CP14a & middle Eocene \\
\hline $10 \mathrm{R}-4,110-111$ & $(+)$ & $\mathrm{CP} 13 \mathrm{c}$ & middle Eocene \\
\hline $10 \mathrm{R}-\mathrm{CC}$ & - & CP13c & - \\
\hline $11 \mathrm{R}-\mathrm{CC}$ & - & CP13c & - \\
\hline 13R-CC & - & $\mathrm{CP} 13 \mathrm{c}$ & - \\
\hline $15 \mathrm{R}-\mathrm{CC}$ & - & CP9a & - \\
\hline $16 \mathrm{R}-\mathrm{CC}$ & - & $\mathrm{CP} 8 \mathrm{~b}$ & - \\
\hline 19R-CC & - & $\mathrm{CP} 3-\mathrm{CP} 4$ & - \\
\hline 20R-CC & - & CP3-CP4 & - \\
\hline $21 R-1,55-56$ & - & CP3-CP4 & - \\
\hline 21R-CC & - & $\mathrm{CP} 3-\mathrm{CP} 4$ & - \\
\hline \multicolumn{4}{|l|}{$115-708 \mathrm{~A}-$} \\
\hline $20 \mathrm{X}-\mathrm{CC}$ & - & CP19b & - \\
\hline $21 X-1,102-103$ & - & CP19b & - \\
\hline $21 \mathrm{X}-\mathrm{CC}$ & - & $C P 19 b$ & - \\
\hline $22 \mathrm{X}-2,102-103$ & - & CP19a & - \\
\hline $22 \mathrm{X}-\mathrm{CC}$ & - & CP19a & - \\
\hline
\end{tabular}

Table 2 (continued).

\begin{tabular}{|c|c|c|c|}
\hline $\begin{array}{l}\text { Core, section, } \\
\text { interval }(\mathrm{cm})\end{array}$ & $\begin{array}{c}\text { Diatom } \\
\text { abundance }\end{array}$ & $\begin{array}{l}\text { Nannofossil } \\
\text { zone }\end{array}$ & $\begin{array}{l}\text { Diatom } \\
\text { zone }\end{array}$ \\
\hline \multicolumn{4}{|l|}{ 115-708A- (Cont.) } \\
\hline $23 \mathrm{X}-5,102-103$ & - & CP19a & - \\
\hline $23 \mathrm{X}-\mathrm{CC}$ & - & CP19a & - \\
\hline $24 X-3,118-119$ & $(+)$ & CP18 & R. vigilans \\
\hline $24 \mathrm{X}-\mathrm{CC}$ & + & CP18 & $R$. vigilans \\
\hline $25 \mathrm{X}-1,102-103$ & $(+)$ & CP18 & $R$. vigilans \\
\hline $25 \mathrm{X}-\mathrm{CC}$ & $(+)$ & CP18 & C. reticulatus \\
\hline \multicolumn{4}{|l|}{$115-709 \mathrm{~B}-$} \\
\hline $22 \mathrm{X}-\mathrm{CC}$ & - & CP19b & - \\
\hline $23 \mathrm{X}-\mathrm{CC}$ & - & CP19b & - \\
\hline $24 \mathrm{X}-\mathrm{CC}$ & - & CP19a & - \\
\hline $25 \mathrm{X}-\mathrm{CC}$ & - & CP19a & - \\
\hline $26 \mathrm{X}-\mathrm{CC}$ & - & CP18 & - \\
\hline $27 \mathrm{X}-2,102-103$ & $(+)$ & CP17-CP18 & - \\
\hline $27 X-5,102-103$ & $(+)$ & CP17-CP18 & - \\
\hline $27 \mathrm{X}-\mathrm{CC}$ & + & CP17-CP18 & C. reticulatus \\
\hline
\end{tabular}

115-709C-

\begin{tabular}{|c|c|c|}
\hline $22 \mathrm{X}-\mathrm{CC}$ & - & CP19b \\
\hline $23 \mathrm{X}-\mathrm{CC}$ & - & CP19b \\
\hline $24 \mathrm{X}-\mathrm{CC}$ & - & CP19a \\
\hline $25 \mathrm{X}-\mathrm{CC}$ & - & $\mathrm{CP} 19 \mathrm{a}$ \\
\hline $26 \mathrm{X}-2,102-103$ & $(+)$ & CP18 \\
\hline $26 \mathrm{X}-5,102-103$ & $(+)$ & CP18 \\
\hline $26 \mathrm{X}-\mathrm{CC}$ & - & CP17 \\
\hline $27 \mathrm{X}-2,102-103$ & - & CP17 \\
\hline $27 X-4,102-103$ & + & CP17 \\
\hline $27 \mathrm{X}-\mathrm{CC}$ & + & CP17 \\
\hline $28 \mathrm{X}-2,102-103$ & $(+)$ & CP17 \\
\hline $28 \mathrm{X}-\mathrm{CC}$ & + & CP17 \\
\hline $29 \mathrm{X}-2,102-103$ & + & CP17 \\
\hline $29 X-5,102-103$ & + & CP16c \\
\hline $29 \mathrm{X}-\mathrm{CC}$ & + & CP16ab \\
\hline $30 \times-2,102-103$ & + & CP16ab \\
\hline $30 \times-5,102-103$ & $(+)$ & CP16ab \\
\hline $30 \mathrm{X}-\mathrm{CC}$ & - & CP15b \\
\hline $31 \mathrm{X}-\mathrm{CC}$ & - & CP15a \\
\hline $32 \mathrm{X}-\mathrm{CC}$ & - & CP15a \\
\hline $33 \mathrm{X}-\mathrm{CC}$ & - & CP14b \\
\hline $34 \mathrm{X}-\mathrm{CC}$ & - & CP14b \\
\hline $35 \mathrm{X}-\mathrm{CC}$ & - & CP13c \\
\hline $36 \mathrm{X}-\mathrm{CC}$ & $(+)$ & CP13c \\
\hline $37 \mathrm{X}-\mathrm{CC}$ & - & CP13b \\
\hline
\end{tabular}

C. reticulatus

C. reticulatus

C. reticulatus

C. reticulatus

C. reticulatus

C. reticulatus

C. reticulatus

C. reticulatus

C. reticulatus

C. excavatus/

C. reticulatus

C. excavatus

late Eocene

-

-

$-$

$-$

-

middle? Eocene

115-710A.

\begin{tabular}{|c|c|c|}
\hline$X-2,102-103$ & - & CP19b \\
\hline $16 \mathrm{X}-\mathrm{CC}$ & - & CP19b \\
\hline $17 X-2,102-103$ & - & CP19b \\
\hline $17 \mathrm{X}-\mathrm{CC}$ & - & $\mathrm{CP} 19 \mathrm{a}$ \\
\hline $18 \times-2,102-103$ & - & $\mathrm{CP} 19 \mathrm{a}$ \\
\hline $18 \mathrm{X}-\mathrm{CC}$ & - & CP19a \\
\hline $19 X-2,102-103$ & - & CP19a \\
\hline $19 X-5,102-103$ & - & CP19a \\
\hline $19 \mathrm{X}-\mathrm{CC}$ & - & CP19a \\
\hline $20 \times-2,102-103$ & - & CP19a \\
\hline $20 \times-5,102-103$ & - & CP18 \\
\hline $20 \mathrm{X}-\mathrm{CC}$ & - & CP18 \\
\hline $21 X-2,102-103$ & - & CP17 \\
\hline $21 X-5,102-103$ & $(+)$ & CP17 \\
\hline $21 \mathrm{X}-\mathrm{CC}$ & - & CP17 \\
\hline $22 X-2,102-103$ & $(+)$ & CP17 \\
\hline $22 \mathrm{X}-\mathrm{CC}$ & - & CP17 \\
\hline
\end{tabular}

$\overline{-}$
$\overline{-}$
$\overline{-}$
$\overline{-}$
$\overline{-}$
$\overline{-}$
$\overline{-}$
C. reticulatus
C. reticulatus
C. reticulatus
C. reticulatus

$\overline{-}$
$\overline{-}$
$\bar{C}$. reticulatus 
Table 2 (continued).

\begin{tabular}{|c|c|c|c|}
\hline $\begin{array}{l}\text { Core, section, } \\
\text { interval }(\mathrm{cm})\end{array}$ & $\begin{array}{c}\text { Diatom } \\
\text { abundance }\end{array}$ & $\begin{array}{l}\text { Nannofossil } \\
\text { zone }\end{array}$ & $\begin{array}{l}\text { Diatom } \\
\text { zone }\end{array}$ \\
\hline \multicolumn{4}{|l|}{ 115-711A- (Cont.) } \\
\hline $14 X-C C$ & - & CP17 & - \\
\hline $15 \mathrm{X}-\mathrm{CC}$ & - & CP16c & - \\
\hline $16 \mathrm{X}-1,102-103$ & + & CP16c & C. reticulatus \\
\hline $16 \mathrm{X}-3,102-103$ & $(+)$ & CP16c & $\begin{array}{l}\text { C. excavatus/ } \\
\text { C. reticulatus }\end{array}$ \\
\hline $16 X-5,102-103$ & - & CP16c & $\begin{array}{l}\text { C. excavatus/ } \\
\text { C. reticulatus }\end{array}$ \\
\hline $16 \mathrm{X}-\mathrm{CC}$ & $(+)$ & CP16ab & C. excavatus \\
\hline $17 \mathrm{X}-1,102-103$ & $(+)$ & CP16ab & B. brunii \\
\hline $17 \mathrm{X}-3,102-103$ & - & CP16ab & - \\
\hline $17 X-5,102-103$ & - & CP16ab & - \\
\hline $17 \mathrm{X}-\mathrm{CC}$ & + & CP15 & B. brunii \\
\hline $18 X-1,103-104$ & $(+)$ & CP15 & A. marylandica \\
\hline $18 X-3,103-104$ & - & CP15 & - \\
\hline $18 \mathrm{X}-\mathrm{CC}$ & - & CP15 & - \\
\hline $19 X-1,102-103$ & - & CP15 & - \\
\hline $19 X-2,7-8$ & $(+)$ & CP15 & A. marylandica \\
\hline $19 X-2,79-80$ & + & CP15 & A. marylandica \\
\hline $19 X-3,102-103$ & $(+)$ & CP14 & A. marylandica \\
\hline $19 X-5,102-103$ & - & CP14 & - \\
\hline $19 \mathrm{X}-\mathrm{CC}$ & - & CP14 & - \\
\hline $20 X-1,102-103$ & - & CP14 & - \\
\hline $20 X-3,45-46$ & - & CP14 & - \\
\hline $20 \mathrm{X}-\mathrm{CC}$ & - & CP14 & - \\
\hline $21 X-3,102-103$ & - & CP14 & - \\
\hline $21 \mathrm{X}-\mathrm{CC}$ & - & CP13c & - \\
\hline $22 X-1,102-103$ & $(+)$ & CP13c & middle? Eocene \\
\hline $22 X-3,102-103$ & - & $\mathrm{CP} 13 \mathrm{c}$ & - \\
\hline $22 \mathrm{X}-\mathrm{CC}$ & - & CP13c & - \\
\hline $23 \mathrm{X}-1,102-103$ & - & $\mathrm{CP} 13 \mathrm{c}$ & - \\
\hline $23 \mathrm{X}-3,102-103$ & - & $\mathrm{CP} 13 \mathrm{c}$ & - \\
\hline $23 \mathrm{X}-\mathrm{CC}$ & - & CP13b & - \\
\hline $24 X-3,102-103$ & - & CP13b & - \\
\hline $24 X-5,102-103$ & - & CP13b & middle? Eocene \\
\hline $24 \mathrm{X}-\mathrm{CC}$ & - & $\mathrm{CP} 13 \mathrm{~b}$ & - \\
\hline $25 X-3,102-103$ & - & CP13a & - \\
\hline $25 \mathrm{X}-\mathrm{CC}$ & - & CP13a & - \\
\hline \multicolumn{4}{|l|}{ 115-711B- } \\
\hline $10 \mathrm{H}-\mathrm{CC}$ & - & CP19b & - \\
\hline $11 \mathrm{H}-\mathrm{CC}$ & - & CP19a & - \\
\hline \multicolumn{4}{|l|}{$115-712 \mathrm{~A}=$} \\
\hline $11 \mathrm{R}-\mathrm{CC}$ & - & CP19a & - \\
\hline $12 \mathrm{R}-1,102-103$ & - & CP14b & - \\
\hline $12 \mathrm{R}-3,102-103$ & - & CP14b & - \\
\hline $12 \mathrm{R}-\mathrm{CC}$ & - & CP14b & - \\
\hline \multicolumn{4}{|l|}{$115-713 \mathrm{~A}-$} \\
\hline $5 \mathrm{R}-1,102-103$ & - & CP14b & - \\
\hline $5 \mathrm{R}-3,102-103$ & - & CP14b & - \\
\hline $5 \mathrm{R}-\mathrm{CC}$ & - & CP14b & - \\
\hline $6 \mathrm{R}-3,102-103$ & $(+)$ & CP14b & middle Eocene \\
\hline 6R-CC & - & CP14b & - \\
\hline $7 R-1,103-104$ & - & $\mathrm{CP} 14 \mathrm{~b}$ & - \\
\hline $7 R-3,103-104$ & $(+)$ & CP14a & middle Eocene \\
\hline $7 R-5,103-104$ & $(+)$ & CP14a & middle Eocene \\
\hline 7R-CC & $(+)$ & CP14a & - \\
\hline $8 \mathrm{R}-1,102-103$ & $(+)$ & $\mathrm{CP} 14 \mathrm{a}$ & middle Eocene \\
\hline $8 \mathrm{R}-3,100-101$ & $(+)$ & CP14a & - \\
\hline $8 \mathrm{R}-\mathrm{CC}$ & $(+)$ & $\mathrm{CP} 13 \mathrm{c}$ & middle Eocene \\
\hline $9 \mathrm{R}-1,102-103$ & $(+)$ & $\mathrm{CP} 13 \mathrm{c}$ & middle Eocene \\
\hline $9 \mathrm{R}-\mathrm{CC}$ & - & CP13c & - \\
\hline 10R-CC & - & $\mathrm{CP} 13 \mathrm{c}$ & - \\
\hline $11 \mathrm{R}-\mathrm{CC}$ & - & $\mathrm{CP} 13 \mathrm{c}$ & - \\
\hline $17 \mathrm{R}-1,91-92$ & - & $\mathrm{CP} 13 \mathrm{c}$ & - \\
\hline \multicolumn{4}{|l|}{$115-714 \mathrm{~A}$} \\
\hline $22 \mathrm{X}-\mathrm{CC}$ & $(+)$ & CP19b & B. veniamini \\
\hline $23 \mathrm{X}-1,102-103$ & $(+)$ & CP19b & B. veniamini \\
\hline $23 \mathrm{X}-3,102-103$ & $(+)$ & $\mathrm{CP} 19 \mathrm{~b}$ & B. veniamini \\
\hline $23 \mathrm{X}-\mathrm{CC}$ & + & CP19a & B. veniamini \\
\hline $24 X-1,102-103$ & $(+)$ & CP19a & Oligocene \\
\hline $24 \mathrm{X}-\mathrm{CC}$ & - & CP19a & Oligocene \\
\hline
\end{tabular}

Table 2 (continued).

\begin{tabular}{|c|c|c|c|}
\hline $\begin{array}{l}\text { Core, section, } \\
\text { interval }(\mathrm{cm})\end{array}$ & $\begin{array}{c}\text { Diatom } \\
\text { abundance }\end{array}$ & $\begin{array}{l}\text { Nannofossil } \\
\text { zone }\end{array}$ & $\begin{array}{c}\text { Diatom } \\
\text { zone }\end{array}$ \\
\hline \multicolumn{4}{|l|}{ 115-714A-(Cont.) } \\
\hline $25 \mathrm{X}-1,102-103$ & $(+)$ & CP19a & - \\
\hline $25 \mathrm{X}-\mathrm{CC}$ & - & CP19a & - \\
\hline \multicolumn{4}{|l|}{$115-715 \mathrm{~A}=$} \\
\hline $14 \mathrm{R}-\mathrm{CC}$ & - & early Eocene & - \\
\hline \multicolumn{4}{|l|}{ 23-219- } \\
\hline $15-1,64-69$ & - & CP17 & - \\
\hline $15-2,56-60$ & - & CP17 & - \\
\hline $15-3,57-62$ & - & CP17 & - \\
\hline $15-5,54-59$ & - & CP17 & - \\
\hline $15-6,54-59$ & - & CP17 & - \\
\hline $16-1,42-47$ & - & CP16 & - \\
\hline $16-2,63-68$ & - & CP16 & - \\
\hline $16-3,63-68$ & - & CP16 & - \\
\hline $16-4,43-48$ & - & CP16 & - \\
\hline $16-4,104-109$ & $(+)$ & CP16 & - \\
\hline $16-5,63-68$ & $(+)$ & CP16 & - \\
\hline $16-6,76-81$ & $(+)$ & CP16 & - \\
\hline $17-1,60-65$ & $(+)$ & CP15 & - \\
\hline $17-1,89-93$ & + & CP15 & - \\
\hline $17-2,44-49$ & + & CP15 & - \\
\hline $17-3,61-66$ & + & CP15 & late Eocene? \\
\hline $17-4,61-66$ & + & CP15 & late Eocene? \\
\hline $17-4,102-106$ & + & CP15 & late Eocene? \\
\hline $17-5,41-46$ & + & CP15 & late Eocene? \\
\hline $17-5,61-66$ & + & CP15 & late Eocene? \\
\hline $18-1,61-66$ & $(+)$ & CP15 & - \\
\hline $18-1,93-98$ & + & CP15 & late Eocene? \\
\hline $18-2,61-66$ & + & CP15 & late Eocene? \\
\hline $18-4,61-66$ & + & CP14 & late Eocene? \\
\hline $18-5,61-66$ & $(+)$ & CP14 & - \\
\hline $18-6,61-66$ & + & CP14 & - \\
\hline $19-1,58-63$ & $(+)$ & CP14 & late Eocene? \\
\hline $19-2,61-66$ & + & CP14 & - \\
\hline $19-3,61-66$ & $(+)$ & CP14 & - \\
\hline $19-4,61-66$ & + & CP14 & - \\
\hline $19-5,61-66$ & + & CP14 & - \\
\hline $19-6,61-66$ & - & CP14 & - \\
\hline $20-1,122-127$ & $(+)$ & CP14 & - \\
\hline $20-2,68-73$ & $(+)$ & CP14 & - \\
\hline $20-3,68-73$ & $(+)$ & CP14 & - \\
\hline $20-4,60-65$ & $(+)$ & CP14 & - \\
\hline $20-5,60-65$ & $(+)$ & CP14 & - \\
\hline $20-6,40-45$ & $(+)$ & CP14 & - \\
\hline $21-1,60-65$ & $(+)$ & CP14 & - \\
\hline $21-2,65-70$ & $(+)$ & CP14 & - \\
\hline $21-3,60-65$ & $(+)$ & CP14 & - \\
\hline \multicolumn{4}{|l|}{$24-236-$} \\
\hline $23-5,60-65$ & - & CP17 & - \\
\hline $24-3,60-65$ & - & CP17 & - \\
\hline $25-3,60-65$ & - & CP16-CP17 & - \\
\hline $26-3,60-65$ & - & CP16 & - \\
\hline $27-2,60-65$ & - & CP16 & - \\
\hline $28-1,46-48$ & + & CP15 & late Eocene? \\
\hline
\end{tabular}

McKenzie and Slater (1971), indicating that all of the sites studied here were located during Eocene and early Oligocene times between $20^{\circ} \mathrm{S}$ and $5^{\circ} \mathrm{N}$ of the equator. The change to more cosmopolitan species in the late early Oligocene and late Oligocene is not a local phenomenon but found also in age-equivalent sediments of other ocean basins, from low and high latitudes (see Fenner 1982, 1984a, 1985).

\section{Eocene}

\section{Mascarene Plateau, Chagos Ridge}

Where middle and late Eocene diatom assemblages are preserved (Cores 115-707A-22X and -23X, 115-707C-3R to -10R, 
Table 3. Occurrence charts of Paleogene diatoms species in Holes 706B, 707A, 707C, and 708A from the Mascarene Plateau and the abyssal plain north of it.

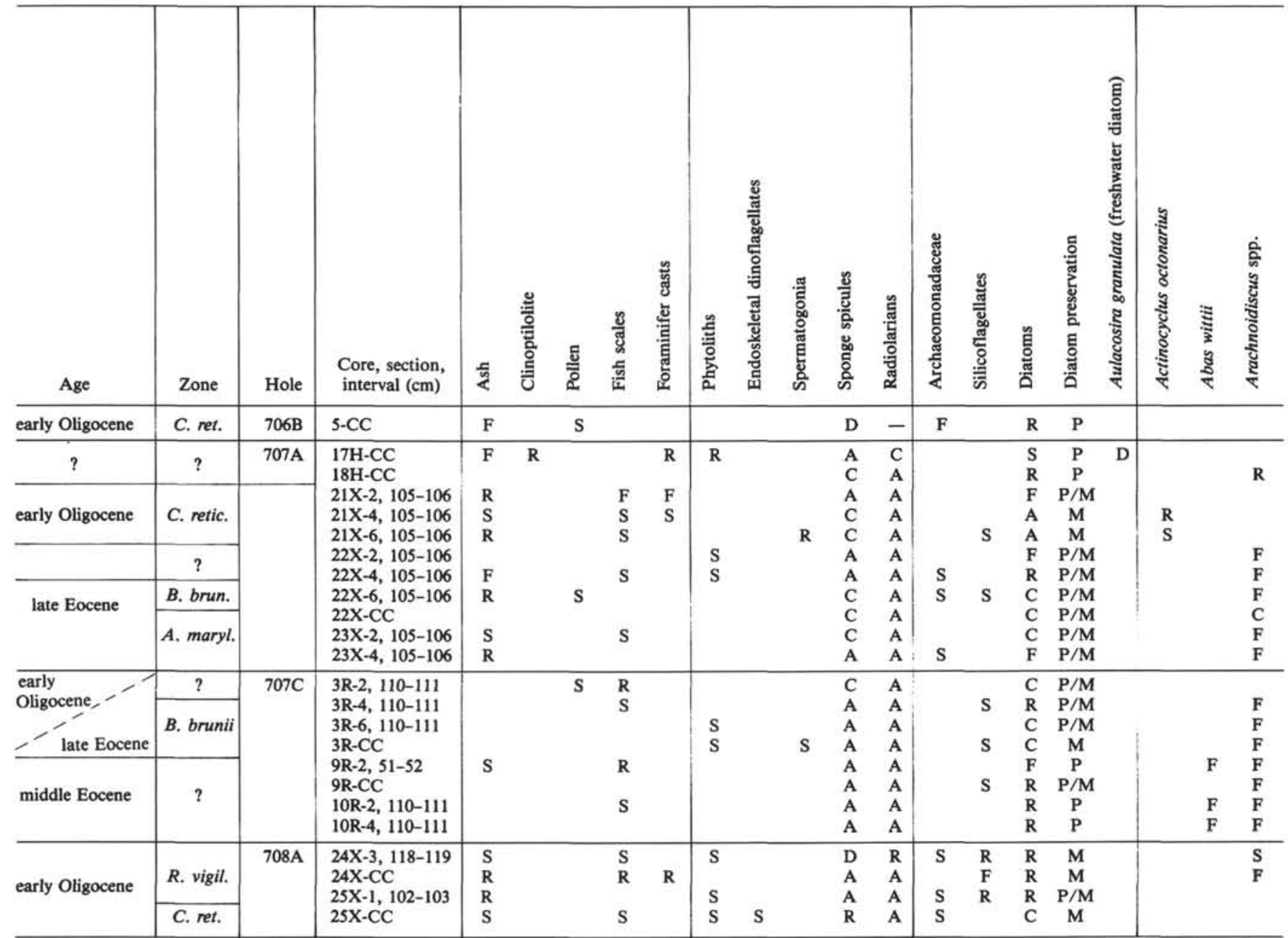

Note: For explanation of symbols for diatom preservation and abundance, see "Methods" section, this chapter.

and $115-713 A-6 R$ to $-9 R$ ), the high abundance of benthic diatom species of the genera Triceratium, Entogonia, Isthmia, Cocconeis, Diploneis, and Arachnoidiscus is conspicuous. Based on benthic foraminifers (Backman, Duncan, et al., 1988), these sequences are interpreted as deposited under middle to upper bathyal conditions. Benthic diatoms account on average for $10 \%-20 \%$ of the diatom assemblages in these sections, with maximum values around $30 \%$.

Most of the benthic, shallow-water diatom species found in the sites from the Indian Ocean were described originally from the Eocene island-arc environments around Barbados (Greville, $1860 \mathrm{ff}$.). The shallow-water diatoms are also allochthonous and embedded in slope sediments there. Barbados, like the other lesser Antilles islands, formed in the open ocean in connection with an active subduction zone, thus creating an environment similar to that of the ridge systems in the Indian Ocean.

In addition to the supply from the coastal environment, the abundance of thickly silicified, more dissolution-resistant valves of shallow-water species is probably enhanced in slope sediments as a result of selective dissolution of the more fragile valves of oceanic species. It is difficult to assess the magnitude of silica dissolution. But whatever its size, upslope from both sites on the northern part of the Chagos Ridge and the Mascarene Plateau (Sites 707 and 713), islands with coastal environments must have existed that supplied the biosiliceous shallowwater components to the area of the drilling sites.

\section{Madingley Rise}

In contrast, Site 709 on the Madingley Rise contains only few and very poorly preserved diatom fragments (Cores 115-709C$30 \mathrm{X}$ and $-36 \mathrm{X})$. These assemblages consist almost entirely of planktonic diatoms with only single and sporadically occurring fragments of shallow-water species. This is interpreted as sediment deposition far away from coastal environments of volcanic islands, inferring that by late Eocene times the Madingley Rise must have subsided to at least below the euphotic zone, if not much deeper. Also, the better-preserved late Eocene diatom assemblages recovered from Site 711 (Cores 115-711A-17X to $-24 X)$ on the abyssal plain north of Madingley Rise reflect deposition in an open-ocean environment.

\section{Oligocene}

Diatomaceous sediments of early Oligocene age were recovered from practically all sites from the Mascarene Plateau and Madingley Rise.

\section{Mascarene Plateau}

By early Oligocene time, the island or islands on the Mascarene Plateau directly upslope from Sites 706 and 707 must have subsided below the euphotic zone, as only sporadic fragments of benthic diatoms are present in the sediments. These fragments very probably were reworked from older shallow-water 
Table 3 (continued).

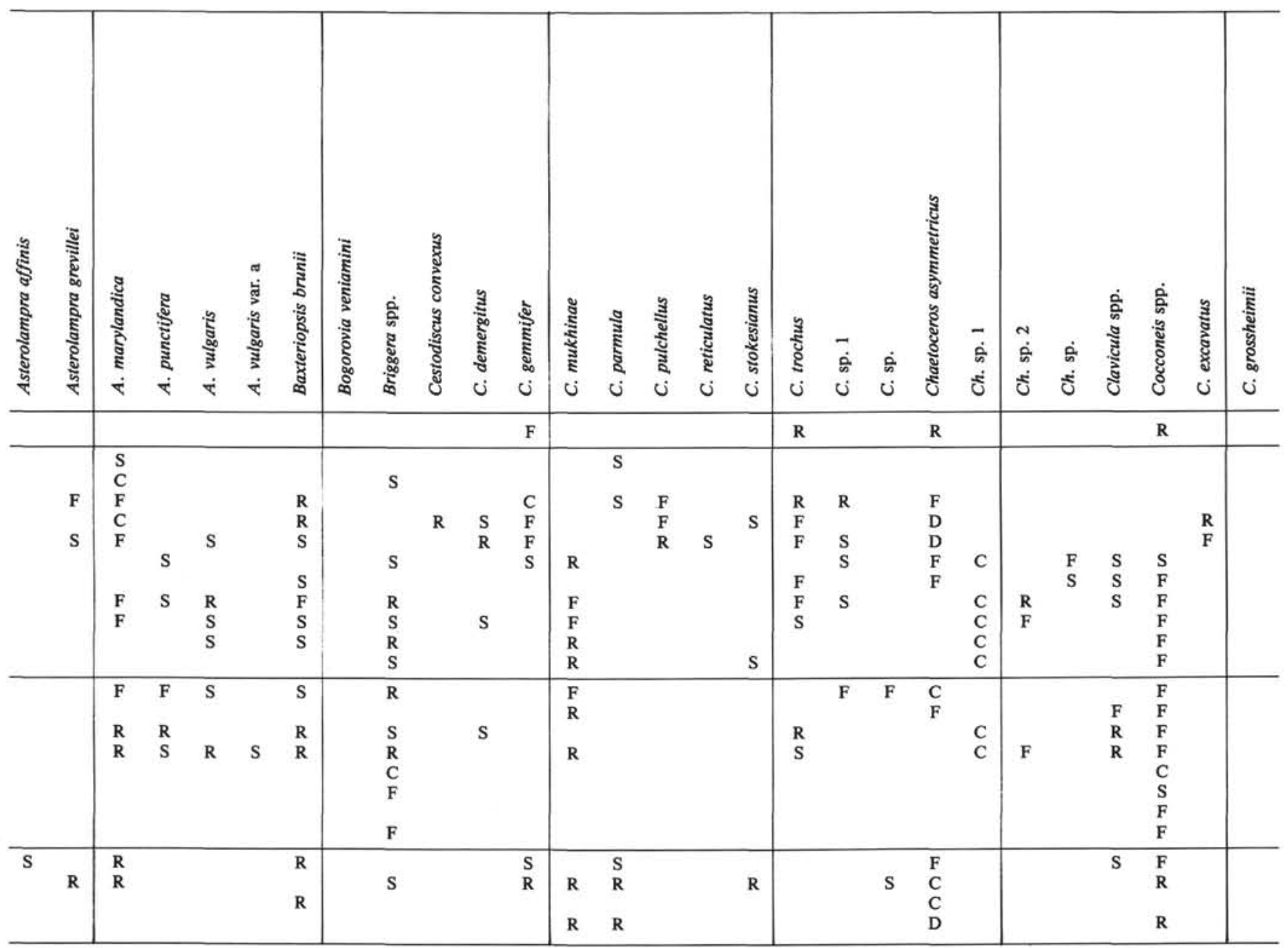

sediments. Only Grammatophora spp., which was common to dominant already in the Eocene sediments at these sites, continues to be common to dominant in the early Oligocene diatom assemblages. The present-day habitat of species of this genus is described (e.g., Simonsen, 1974) as littoral and also present in the plankton of the shelf areas. Thus, the dominance of this species in the assemblages is not in conflict with the proposed subsidence of the upslope areas to below the euphotic zone. In addition, one of the authors (J. Fenner) has found that the septa of Grammatophora spp. are very dissolution resistant, and in strongly dissolved Oligocene assemblages these septa are frequently the last diatom-derived particles to be dissolved. Thus, their high abundance in the sequences studied is a result, at least in part, of selective dissolution.

\section{Madingley Rise}

Like during the Eocene, diatoms recovered from Sites 709 and 710 on the Madingley Rise continue to reflect sedimentation unaffected by shallow-water input also during the Oligocene. In the abyssal sites (in abyssal Site 708 on the abyssal plain between the Mascarene Plateau and the Madingley Rise and Site 711 north of the Madingley Rise), the Oligocene sections furnish a few benthic shallow-water diatoms. These diatoms have presumably been transported over long distances, as the sections are characterized by frequent interbedded turbidites (Backman, Duncan, et al., 1988). Based on reworking of planktonic fora- minifers, Premoli Silva and Spezzaferri (this volume) believe that the source area of the turbidites is well below the lysocline. Diatom assemblage analyses point in the same direction. The scarcity of shallow-water diatoms and of reworked diatoms in these turbidite sediments indicate that they must have originated from a region rarely reached by dislocated coastal diatoms. Turbidite sedimentation is not recorded at the abyssal DSDP Site 236 northeast of the Seychelles Islands. Furthermore, this site is far from land; therefore, it is not astonishing that only very rare diatom remains are found.

Late Oligocene sediments are generally barren of diatoms or have been eroded as at Sites 219 and 713 on the Chagos-Laccadive Ridge. Only at Site 714 on the northern Maldives Ridge are moderately preserved diatom assemblages of late Oligocene age encountered. These assemblages with admixed benthic diatoms reflect a deposition not too far away from a coastal island environment.

A few late early Oligocene and late Oligocene samples from Sites 707,709 , and 714 (Tables 3-5) contain relatively high numbers of freshwater diatoms (in Hole 707A, up to approximately $50 \%$ ). These occurrences of the freshwater diatom Aulacosira granulata are interpreted as wind-blown since no brackish water and benthic freshwater diatoms co-occur. If this conclusion is correct, periods of at least seasonally arid conditions have to be assumed for the source areas of these diatoms (eastern Africa and India, respectively) in the late early Oligocene and the late Oligocene. 
Table 3 (continued).

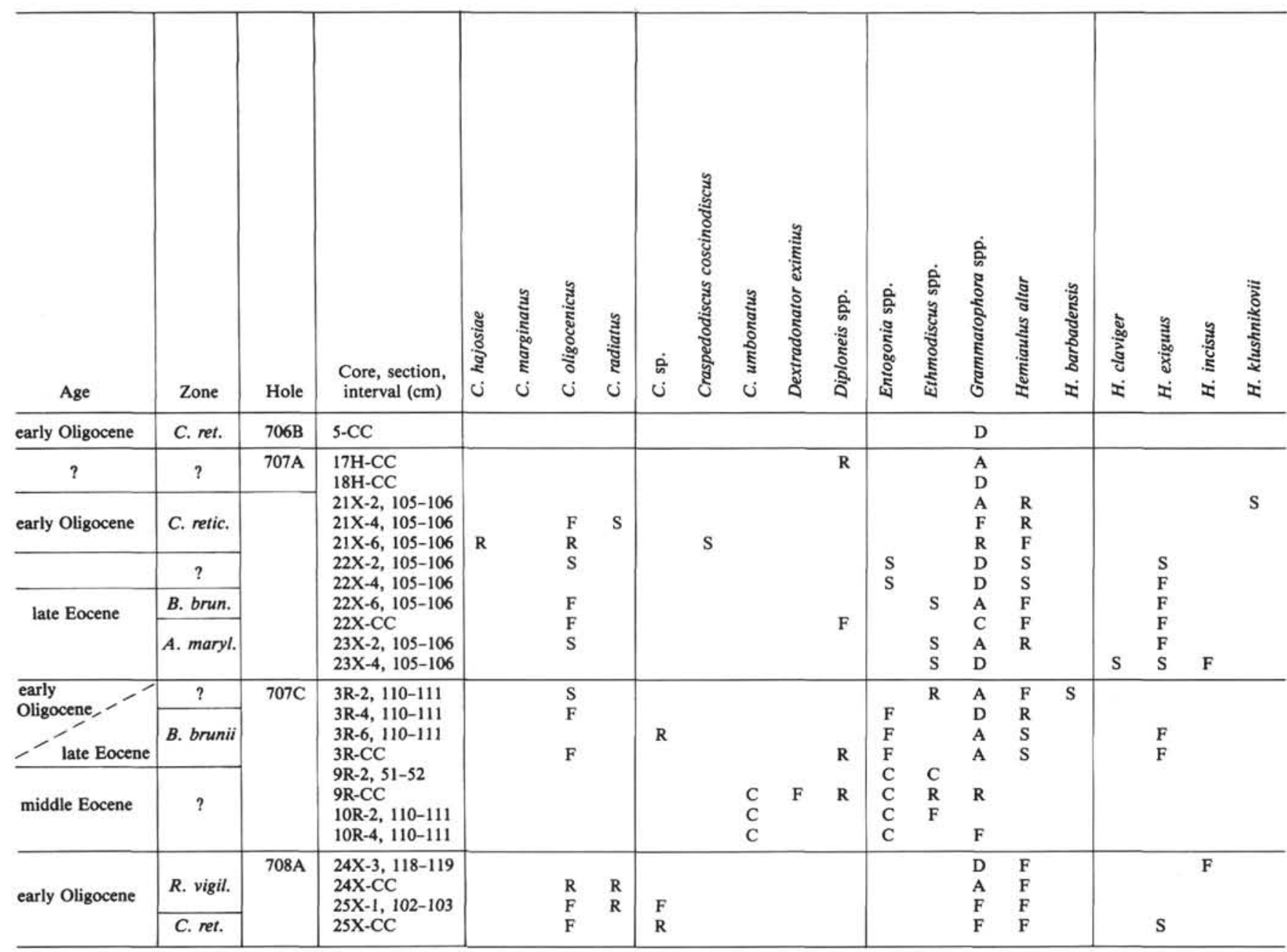

\section{TAXONOMY}

All species encountered in the Eocene-Oligocene sequences studied are listed alphabetically in the following taxonomic list. References to the first description, and in some cases to a later, more informative description, and a better illustration are provided. For a comprehensive list of synonyms, the reader is referred to Mills (1933-1935) and Van Landingham (1967-1979).

\section{Genus ACTINOCYCLUS Ehrenberg (1837)}

Actinocyclus octonarius Ehrenberg (1837)

Description. Hustedt (1930), sp. 525-528, fig. 298 as A. ehrenbergii Ralfs in Pritchard (1861).

Genus $A B A S$ Ross and Sims (1980)

Abas wittii (Grunow) Ross and Sims (1980)

Description. Van Heurck (1880-1885), pl. 106, fig. 4 (1883), Ross and Sims (1980), p. 120, pl. 2, figs. 10-15.

\section{Genus ACTINOPTYCHUS Ehrenberg (1841)}

Actinoptychus senarius Ehrenberg (1837)

Description. Hustedt (1930), pp. $475-478$, fig. 264 as $A$. undulatus (Bailey) Ralfs, in Pritchard (1861).

Remark. All "senarius-like" species, which have six alternatively raised or depressed radial sectors and no special structure (e.g., hyaline central or marginal areas), were listed under this name.
Actinoptychus splendens (Shad.) Ralfs in Pritchard (1861)

Description. Hustedt (1930), pp. 478-479, fig. 265.

Genus ARACHNOIDISCUS Deane ex Pritchard (1852) Arachnoidiscus spp.

Remarks. All recent species of this genus are littoral (Hustedt, 1930). Therefore, the occurrence of species of this genus has been used in this study as a paleoenvironmental indicator. Taxonomic identification was not pursued to the species level.

\section{Genus ASTEROLAMPRA Ehrenberg (1844a)}

Asterolampra affinis Greville (1862)

Description: Greville (1862), pp. 45-46, pl. 7, figs. 7-9.

Asterolampra grevillei (Wallich) Greville (1860)

Description. Hustedt (1930), p. 489, fig. 274.

$$
\text { Asterolampra marylandica Ehrenberg (1844a) }
$$

Description. Hustedt (1930), pp. 485-487, fig. 271.

Asterolampra punctifera (Grove) Hanna (1927)

Synonym. Asterolampra affinis Grev. var. punctifera Grove (1896) in A. Schmidt et al. (1874- ), pl. 202, fig. 18.

Description. Hanna (1927), p. 109, pl. 17, fig. 3. 


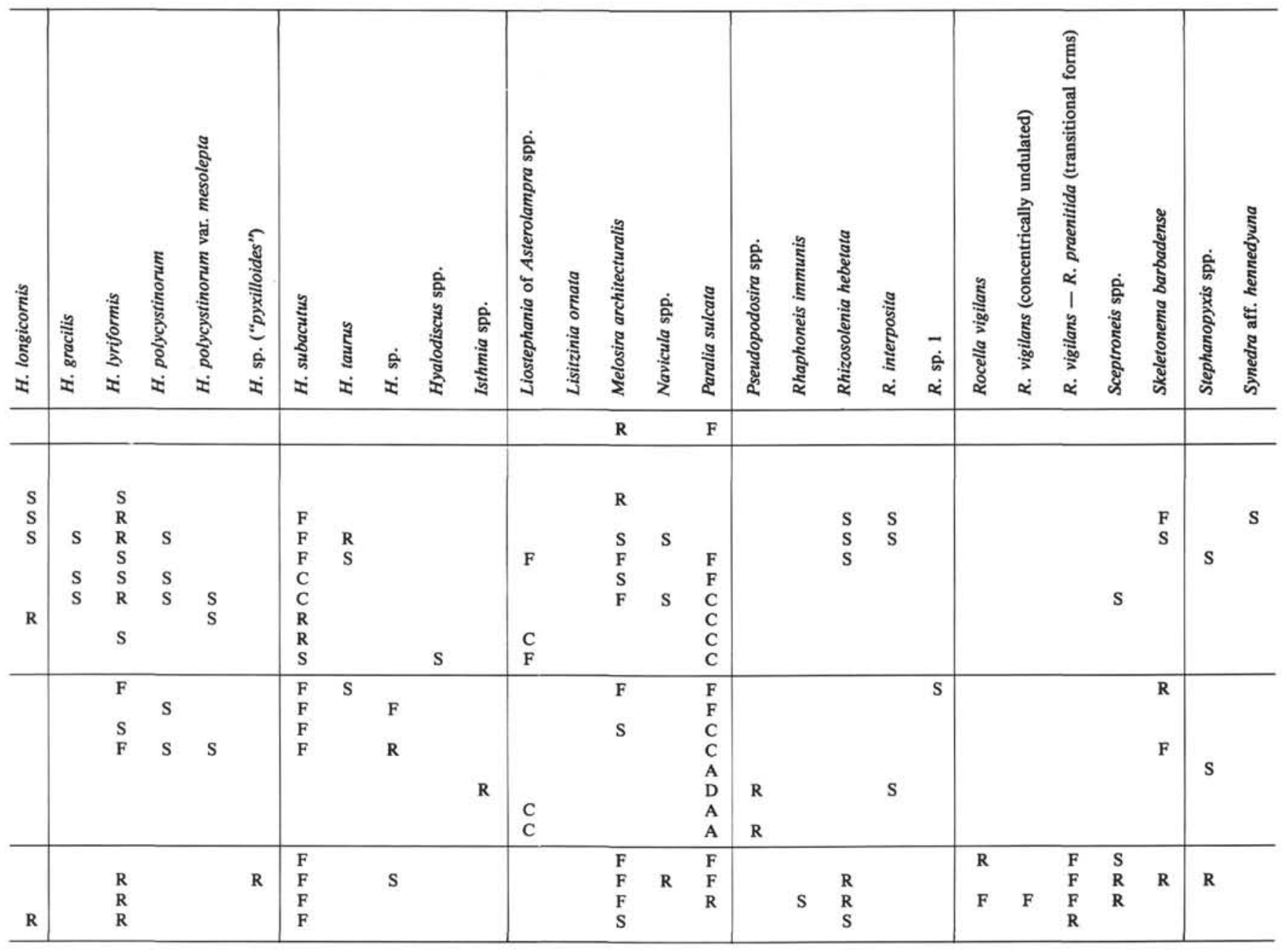

Asterolampra vulgaris Greville (1862)

Description. Greville (1862), p. 47, pl. 7, figs. 17-25; Fenner (1985), p. 727 , fig. 7.27 .

\section{Genus AULACODISCUS Ehrenberg (1844a) Aulacodiscus spp.}

Remarks. Species of the genus Aulacodiscus are known to be predominantly littoral. The occurrences of species of this genus were used in this study as paleoenvironmental indicators. Determination to the species level was not done.

\section{Genus AULACOSIRA (AULACOSEIRA) Thwaites (1848)}

$$
\text { Aulacosira gramulata (Ehr.) Simonsen (1979) }
$$

Description. Hustedt (1930), pp. 248-252, figs. 104-105.

Remarks. This species is a planktonic freshwater species and allochthonous in marine sediments. It is known from sediments of middle Eocene age to the present. Varieties of this species were not differentiated.

\section{Genus BAXTERIOPSIS Karsten (1928)}

Baxteriopsis brunii (Van Heurck) Karsten (1928)

Description. Van Heurck (1896), p. 460, fig. 190 as Baxteria brunii, Fenner (1985), p. 727, fig. 10.7-10.8.

\section{Genus BOGOROVIA Jousé (1974)}

Bogorovia veniamini Jousé (1974)

Description. Jousé (1974), p. 351, pl. 4, figs. 1-3.
Genus BRIGGERA Ross and Sims (1985)

\section{Briggera spp.}

Remarks. Species of this genus were not differentiated because no complete specimens were found.

\section{Genus CESTODISCUS Greville (1865b) \\ Cestodiscus convexus Castracane (1886)}

Synonym. Cestodiscus pulchellus Grev. sensu Jousé (1974), p. 345, 348 , pl. 1, figs. 12-13.

Description. Castracane (1886), p. 123, pl. 7, fig. 6.

Cestodiscus demergitus (Fenner) comb. nov.

Synonym. Coscinodiscus demergitus Fenner (1978), p. 514, pl. 4, figs. 1-3.

Description. Fenner (1978), p. 514, pl. 4, figs. 1-3.

Remarks. Because of the marginal ring of labiate processes and the lack of any other labiate process on the valve face, and because of the structurally offset margin, this species is transferred to the genus Cestodiscus Grev.

\section{Cestodiscus gemmifer Castracane (1886)} Plate 1, Figure 3

Synonyms. Coscinodiscus superbus Hardman, ms, in Rattray (1889), p. 458; Cestodiscus aff. pulchellus Jousé (1974) in part, Jousé (1974), pl. 1, fig. 11, not figs. 9-10.

$$
\text { Cestodiscus mukhinae Jousé (1974) }
$$

Description. Jousé (1974), pp. 344-345, pl. 1, figs. 1-5. 
Table 3 (continued).

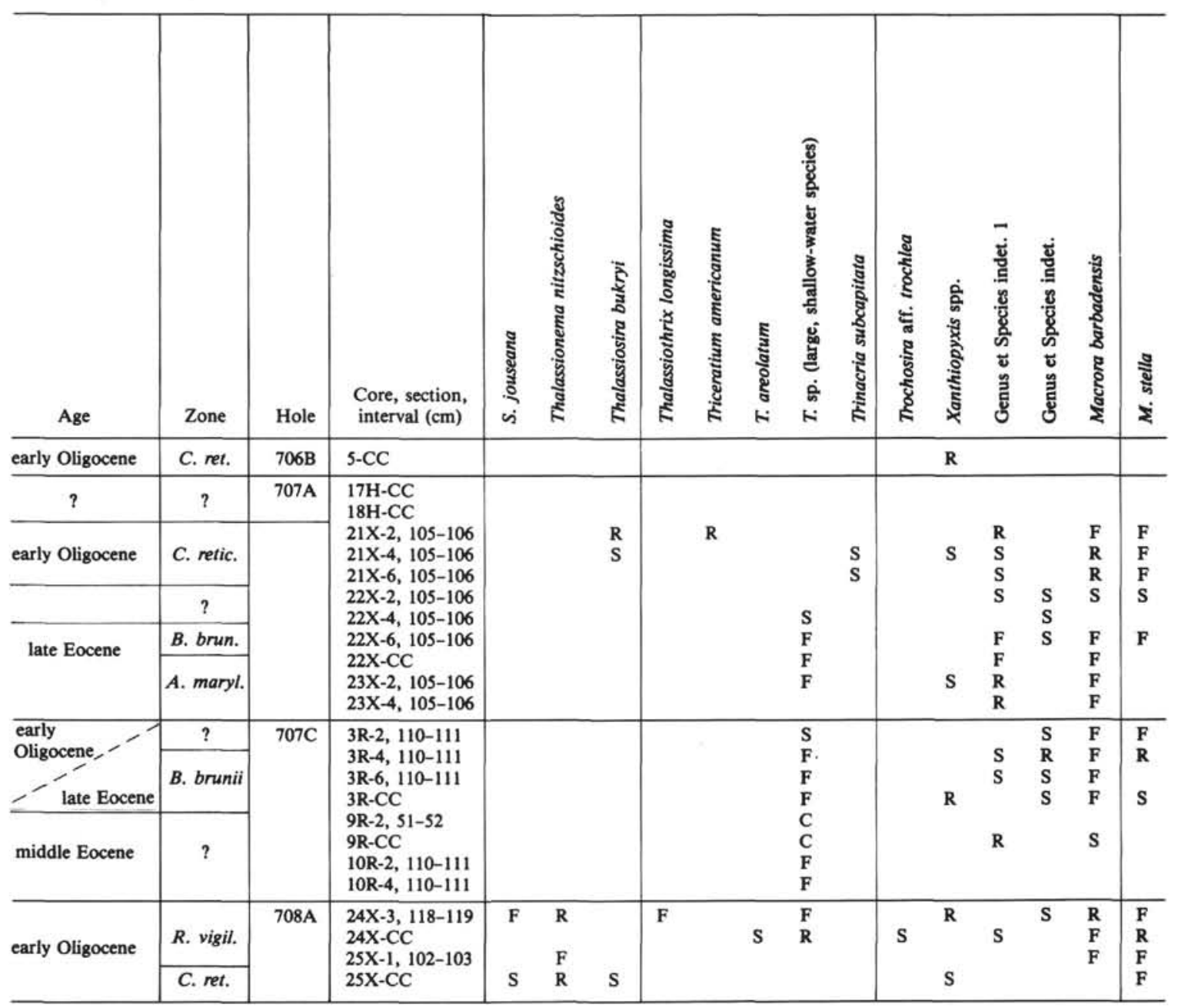

Cestodiscus parmula Castracane (1886)

Description. Castracane (1886), p. 125, pl. 7, fig. 5. Cestodiscus pulchellus Greville (1866b)

Description. Greville (1866b), p. 123, pl. 11, fig. 5. Cestodiscus reticulatus Fenner (1984a)

Description. Fenner (1984a), p. 331, pl. 1, fig. 10. Cestodiscus stokesianus Greville (1866b)

Description. Greville (1866b), p. 123, pl. 11, fig. 4.

\section{Cestodiscus trochus Castracane (1886)}

Description. Castracane (1886), p. 123, pl. 7, figs. 1 and 3.

\section{Cestodiscus sp. 1}

Description. The valve outline is circular. The valves have an undulated valve face and a steep margin. The valve diameter varies between 20 and $100 \mu \mathrm{m}$. The number of areolae is $4-6$ in $10 \mu \mathrm{m}$. A ring of marginal processes is present along the upper border of the structurally offset margin.

\section{Genus CHAETOCEROS Ehrenberg (1844b)}

Chaetoceros asymmetricus Fenner sp. nov.

$$
\text { Plate 5, Figures 3-4 }
$$

Description. From a rather small, convex valve of oval outline two setae rise. One is relatively robust, carries punctae, and is curved. The other is much thinner and mostly broken off close to the valve face. On the sloping valve face between the center and the margin of the valve, a circular area is surrounded by spines. In the center of this area, a large, inward protruding, labiate process is located.

Paleogeographic occurrence. This species was found in early Oligocene sediments off northwest Africa (Fenner, 1982; listed as Chaetoceros sp. 1) and in all early Oligocene diatomaceous Leg 115 sediments.

Differential diagnosis. This species differs from all other species of the genus Chaetoceros by the two very different setae on the valve face, the position of the labiate process, and the structure surrounding it.

Holotype. Plate 5, Figure 3, from DSDP Sample 41-369A-22-5, 128$129 \mathrm{~cm}$.

\section{Chaetoceros sp. 1}

Description. Only fragments of the setae of this species were found. They are robust and curved and carry punctae.

\section{Chaetoceros sp. 2 \\ Plate 5, Figure 5}

Description. The setae of this species have longitudinal ribs and punctae in between the depressions. Characteristic is an inflation of the setae. Because this inflation is fairly robust and thickly silicified, it is often the only part that is preserved of this species.

\section{Genus CLAVICULA Pantocsek (1886)}

\section{Clavicula spp.}

Remarks. Only fragments of species belonging to this genus were found. 
Genus COCCONEIS Ehrenberg (1838b)

Cocconeis spp.

Plate 2, Figure 1

Remarks. All recent species of this genus are today living attached to a substratum, and most of them are shallow-water species. Some were found attached to whale skins and thus survived in the oceanic environment (Hart, 1935). In the material studied, some very large species were found (e.g., Plate 2, Fig. 1).

\section{Genus COSCINODISCUS Ehrenberg (1838b) \\ Coscinodiscus argus Ehrenberg (1838b)}

Description. Hustedt (1930), pp. 422-424, fig. 226.

Coscinodiscus excavatus Greville in Pritchard (1861)

Synonyms. Coscinodiscus diophthalamus Castracane (1886), p. 163, pl. 16, fig. 4; Coscinodiscus sellatus Jousé (1974), p. 348-349, pl. 2, figs. $2-4$.

Description. Greville ms, Ralfs, in Pritchard (1861), p. 829, pl. 8, fig. 26; Grunow (1884), p. 73.

Coscinodiscus extravagans A. Schmidt (1878) in A. Schmidt et al. (1874-)

Description. A. Schmidt et al. (1874- ), pl. 58, fig. 33; Rattray (1889), p. 506.

Coscinodiscus grossheimii Gleser in Sheshukova-Poretzkaya and Gleser (1962)

Description. Sheshukova-Poretzkaya and Gleser (1962), p. 178, pl. 1, figs. 5a-b.

\section{Coscinodiscus hajosiae Fenner (1984a)}

Synonym. Coscinodiscus spiralis sensu Hajós (1976), p. 826, pl. 7, figs. 1-3, non: Coscinodiscus spiralis Karsten (1905), p. 81, pl. 5, figs. $5 \mathrm{a}-\mathrm{b}$.

Description. Hajós (1976), p. 826, pl. 7, figs. 1-3; Fenner (1984a), p. 331 , pl. 2, fig. 2.

\section{Coscinodiscus lewisianus Greville (1866a)}

Description. Greville (1866a), p. 78, pl. 8, figs. 8-10. Coscinodiscus marginatus Ehrenberg (1841a)

Description. Hustedt (1930), p. 416, fig. 223.

Coscinodiscus nodulifer A. Schmidt (1878) in A. Schmidt et al. (1874- )

Description. A. Schmidt et al. (1874- ), pl. 59, fig. 20-23; Hustedt (1930), pp. 426-427, fig. 229.

\section{Coscinodiscus oligocenicus Jousé (1974)}

Description. Jousé (1974), p. 348, pl. 1, figs. 6-8 and 16; Fenner (1978), pp. 515-516, pl. 4, figs. 5-10.

Coscinodiscus radiatus Ehrenberg 1839 (1841)

Description. Hustedt (1930), pp. 420-421, fig. 225.

Coscinodiscus rhombicus Castracane (1886)

Description. Castracane (1886), p. 164, pl. 22, fig. 11; Fenner (1985), p. 729 , fig. 7.14

\section{Genus CRASPEDODISCUS Ehrenberg (1844c)}

Craspedodiscus coscinodiscus Ehrenberg (1844c)

Description. Schmidt et al. (1874- ), pl. 66, fig. 3-5, Ehrenberg (1844a), p. 266, fig. 12.

Craspedodiscus oblongus (Grev.) Grunow (1878) in A. Schmidt et al. (1874- )

Synonym. Porodiscus oblongus Grev. (1863b), p. 65, pl. 4, fig. 5 (illustration mislabeled Porodiscus ovalis).

Description. Gombos (1982), p. 232, figs. 16-17.
Craspedodiscus umbonatus Greville (1866a).

Plate 3, Figure 8

Synonym. Genus et species indet. 2, Fenner 1984b, p. 1263, pl. 2, fig. 5 .

Description. Greville (1866a), p. 79, pl. 8, fig. 15 .

Genus DEXTRADONATOR Ross and Sims (1980)

Dextradonator eximius (Grunow) Ross and Sims (1980)

Plate 2, Figures 6 and 12

Description. Van Heurck (1880-1885), pl. 106, figs. 1 and 3 (1883); Ross and Sims (1980), p. 118, pl. 1, figs. 1-4.

\section{Genus DIPLONEIS Ehrenberg (1840)}

Diploneis spp.

Remarks. Specimens belonging to this genus were only sporadically found. All species of this genus lived attached to a substratum and are considered shallow-water species.

Genus ENDICTYA Ehrenberg (1845)

Endictya robustus (Grev.) Hanna and Grant (1926)

Description. Hanna and Grant (1926), p. 144, pl. 16, figs. 2-3.

Genus ENTOGONIA Greville (1863b)

Entogonia spp.

Plate 3, Figure 3

Remarks. Because only fragments of species belonging to this genus were found, determination to the species level was not done. All members of this genus are considered to be shallow-water species.

\section{Genus ETHMODISCUS Castracane (1886)}

Ethmodiscus spp.

Remarks. Only fragments of species of this genus were found.

Genus GRAMMATOPHORA Ehrenberg (1839)

Grammatophora spp.

Remarks. Septa belonging to species of this genus were abundant, especially in diatom-bearing early Oligocene sediments. These septa seem to be one of the most dissolution-resistant skeletal remains of diatoms.

\section{Genus HEMIAULUS Ehrenberg (1844a) \\ Hemiaulus aff. affinis Grunow in Van Heurck (1883)}

Description. Van Heurck (1883), pl. 106, figs. 10-11.

\section{Hemiaulus altar Brun (1896)}

Plate 4, Figure 5

Description. Brun (1896), p. 238, pl. 20, figs. 19 and 20 .

Hemiaulus barbadensis Grunow (1884)

Description. Grunow (1884), p. 63.

Hemiaulus bipons (Ehr.) Grunow in Van Heurck (1882)

Synonym. Biddulphia suborbicularis Barron (1975), p. 126, pl. 4, fig. 17.

Description. Van Heurck (1882), pl. 103, figs. 6-9, Grunow (1884), p. 65 .

Hemiaulus claviger A. Schmidt in Schmidt et al. (1874- ) Plate 4, Figure 6

Description. A. Schmidt et al. (1874- ), pl. 143, figs. 5 and 6.

Hemiaulus dubius Grunow (1884)

Description. Grunow (1884), p. 61, pl. 5(E), fig. 54.

Hemiaulus exiguus Greville (1865a)

Description. Greville (1865a), p. 29, pl. 4, fig. 20; Fenner (1985), p. 731, fig. 8.6-8.7. 
Table 4. Occurrence charts of Paleogene diatom species from the Madingley Rise sites (Holes 709C, 710A, and 711A).

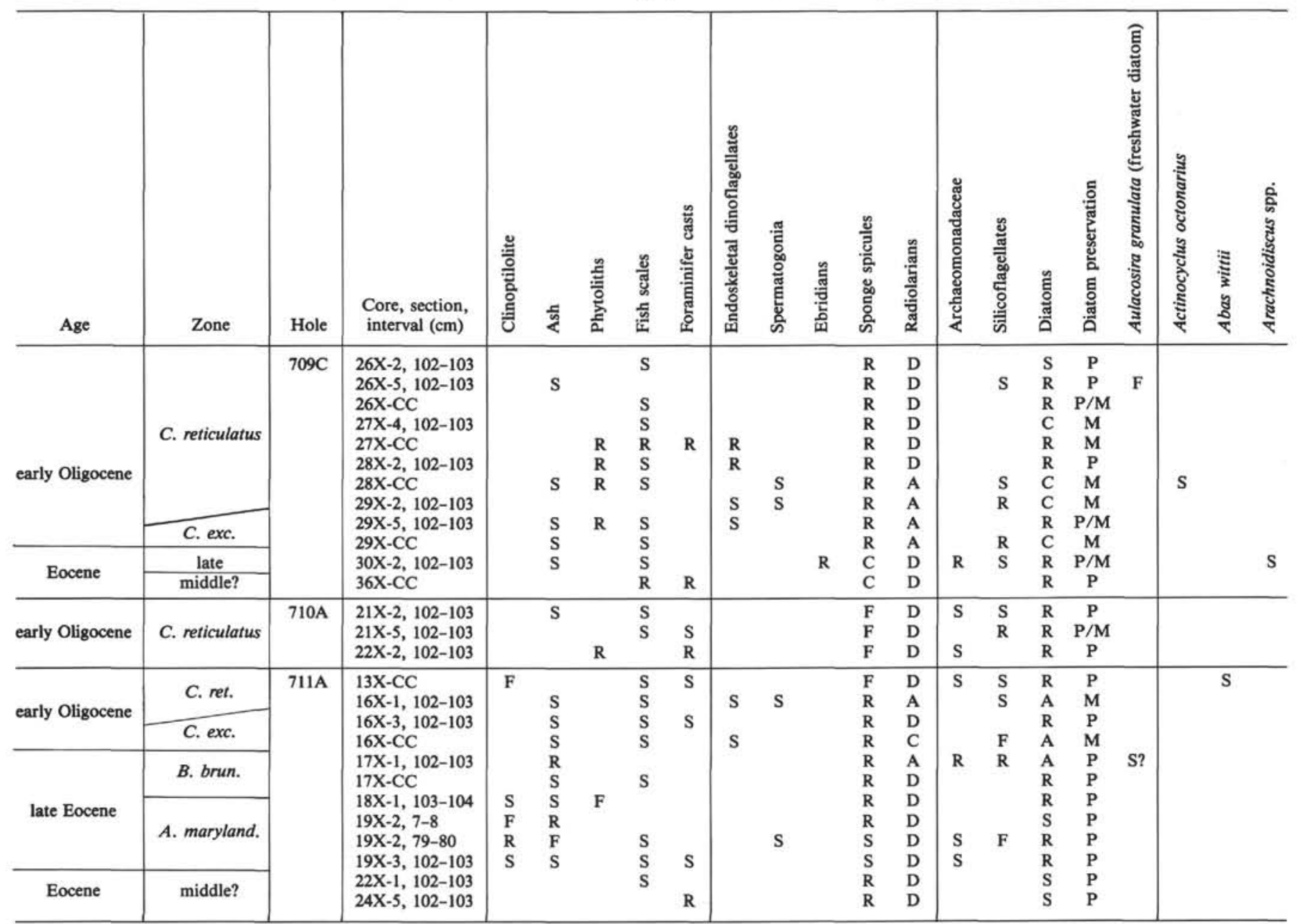

Note: For explanation of symbols for diatom preservation and abundance, see "Methods" section, this chapter.

\section{Hemiaulus gracilis Fenner sp. nov.} Plate 5, Figures 8-9

Description. The valve outline is lanceolate. The valves are thin and delicate. The long apical prolongations are narrow and carry a straight upward-pointing spine on their top. The central part of the valve is highly domed. The round opening in its center is the external opening of the labiate process. One row of pores is found on each of the apical prolongations. Across the valve face connecting the basal parts of the two apical prolongations spans a thin siliceous sheet, which is characteristically stabilized by a net of thin, anastomosing ridges on it.

Differential diagnosis. No similar species were found in the literature.

Stratigraphic and paleogeographic occurrence. This species was found in the latest Eocene and early Oligocene sediments off northwest Africa (DSDP Sites 366 and 369A; Fenner, 1982) and in the Indian Ocean (Sites 707 and 709).

Holotype. Plate 5, Figure 8 from DSDP Sample 41-366-10-6, 132$133 \mathrm{~cm}$.

Hemiaulus incisus Hajós (1976)

Description. Hajós (1976), p. 829, pl. 23, figs. 4-9.

Hemiaulus klushnikovii Gleser in Sheshukova-Poretzkaya and Gleser (1964). fig. 8

Description. Sheshukova-Poretzkaya and Gleser (1964), p. 87, pl. 3,

\section{Hemiaulus longicornis Greville (1865a)} Plate 4, Figures 12-13

Description. Greville (1865a), p. 31, pl. 3, fig. 13.

\section{Hemiaulus lyriformis Greville (1865a)}

Description. Greville (1865a), p. 30, pl. 3, fig. 11; Fenner (1985), p. 732, fig. 10.15 ,

\section{Hemiaulus polycystinorum (Ehr.) Grunow (1884)}

Deseription. Grunow (1884), p. 65; Cleve-Euler (1951), p. 125; A. Schmidt et al. (1874- ), pl. 143, figs. 24(?) and 28.

Hemiaulus polycystinorum Ehr. var. mesolepta Grunow (1884)

Description. Grunow (1884), p. 65, pl. 2(B), fig. 43; Fenner (1985), p. 733 , fig. 8.10 .

Hemiaulus rectus var. twista Fenner (1984a)

Description. Fenner (1984a), p. 332, pl. 2, fig. 6.

Hemiaulus robustus Greville (1865b)

Plate 2, Figure 11

Description. Greville (1865b), p. 54, pl. 6, fig. 23.

Hemiaulus subacutus Grunow (1884)

Plate 2, Figure 10

Deseription. Grunow (1884), p. 61, pl. 5(E), fig. 55; Fenner (1978), p. 522 , pl. 24 , figs. 8 and 14 .

Hemiaulus taurus Gombos in Gombos and Ciesielski (1983) Plate 2, Figure 8

Description. Gombos and Ciesielski (1983), p. 606, pl. 19, figs. 1-8. Hemiaulus sp. (pyxilloides) Schrader and Fenner (1976)

Description. Schrader and Fenner (1976), p. 984, pl. 10, figs. 1-3. 
Table 4 (continued).

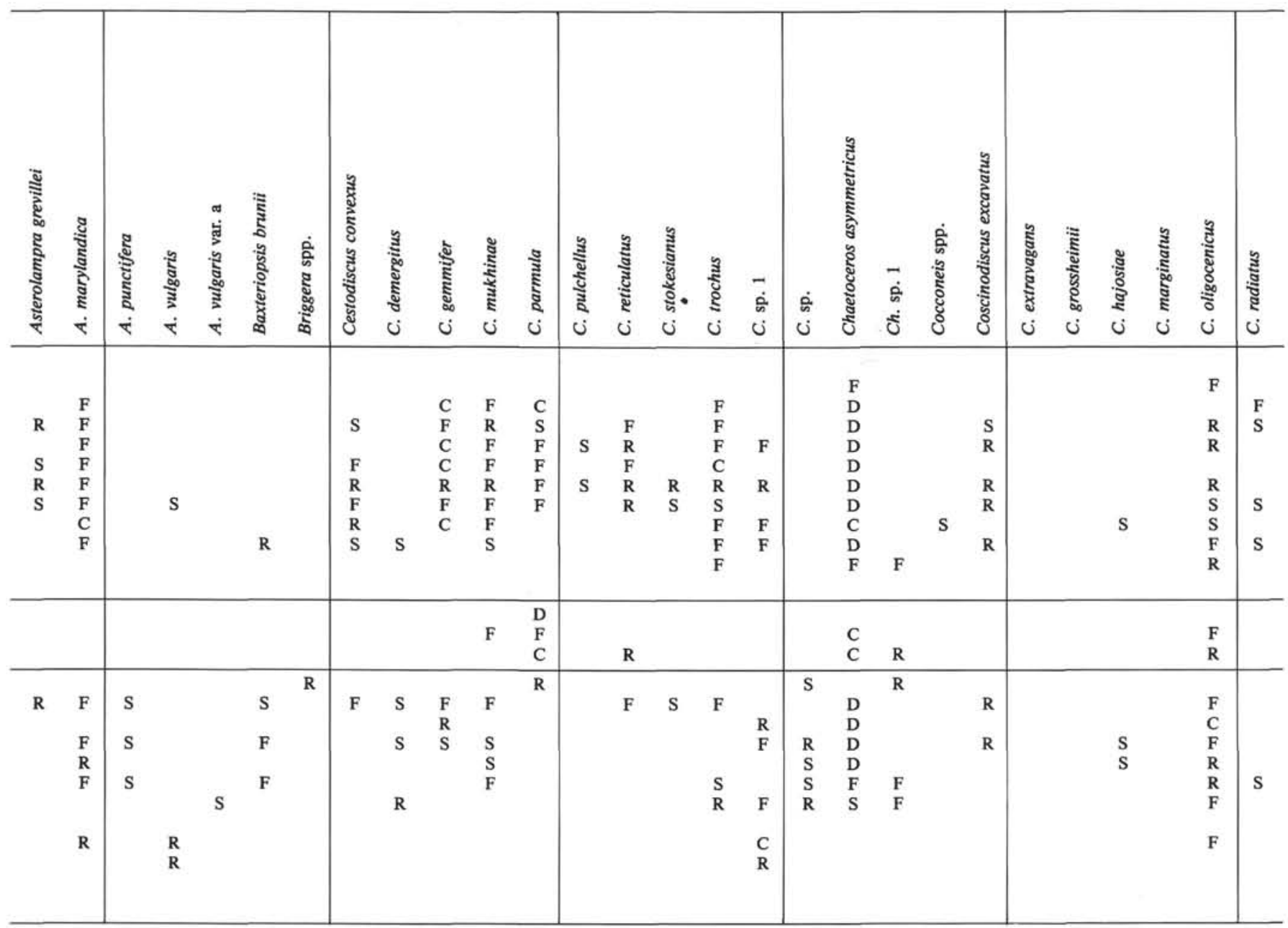

Genus HYALODISCUS Ehrenberg (1845)

Remarks. Species belonging to this genus were extremely rare and therefore were not determined to the species level.

\section{Genus ISTHMIA Agardh (1832)}

Isthmia sp.

Plate 3, Figure 9

Remarks. Only fragments of a species and one complete specimen belonging to this genus were found in the Eocene sediments of Site 707.

\section{Genus KOZLOVIELLA Jousé (1974)}

Kozloviella meniscosa Fenner sp. nov. Plate 5, Figures 1-2

Description. The valve outline is broadly sickle-shaped, with one side convex, and the other concave to straight. The shorter axis of the valve diameter varies between 55 and $100 \mu \mathrm{m}$. The valve is slightly convex. The areolae are arranged in rows that radiate from the hyaline area and are slightly curved near the poles. The areolae are larger in the central part of the valve (6-7 areolae in $10 \mu \mathrm{m})$ than in the marginal part $(10-12$ areolae in $10 \mu \mathrm{m})$. The areolae have an outer cribrum that has the shape of cross- or tripod-like bars. These rather robust cribra, or at least their remnants, the siliceous thickenings on the areolae margin where the bars are broken off, are characteristic for this species and are always observed. The hyaline rays that radiate from the hyaline area end at the margin in a small process. The margin is hyaline.

Differential diagnosis. This species differs from Kozloviella pacifica Jousé by its valve shape and the position of the hyaline area eccentrically displaced toward the concave side.
Stratigraphic and paleogeographic occurrence. At DSDP Sites 366 and 369A off northwest Africa (Fenner, 1982), this species ranges from the late middle Eocene (planktonic foraminifer Zone P14) into the early Oligocene (planktonic foraminifer Zone P19). In addition to its occurrence at Site 709, it is also found by one of the authors (J. Fenner) in late Eocene-early Oligocene sediments from higher latitudes (i.e., DSDP Sites 277,328 , and 511 ). $\mathrm{cm}$

Holotype. Plate 5, Figure 1, from DSDP Sample 41-366-10-4, 89-90

$$
\text { Kozloviella subrotunda Fenner (1984a) }
$$

Description. Fenner (1984a), pp. 332-333, pl. 2, fig. 2.

\section{Liostephania spp. \\ Plate 2, Figures 2-4}

Remarks. Liostephania Ehr. is interpreted by A. Schmidt in A. Schmidt et al. (1874- ), by Hanna and Brigger (1970), and by Schrader $(1974$, p. 919$)$ as internal opal molds of valves. They are found especially in the middle and late Eocene, where they belong to species of the genus Asterolampra. In the early Oligocene, where Liostephania has a rare occurrence, they are not only from the genus Asterolampra but also of Asteromphalus, Paralia(?), and Coscinodiscus(?). Because the discus of Liostephania are very solution resistant, they become concentrated in poorly preserved diatom assemblages.

\section{Genus LISITZINIA Jousé (1978)}

Lisitzinia ornata Jousé (1978)

Description. Jousé (1978), p. 47-48, pl. 10, figs. 1-6; Fenner (1985), p. 734 , fig. 10.11 . 
Table 4 (continued).

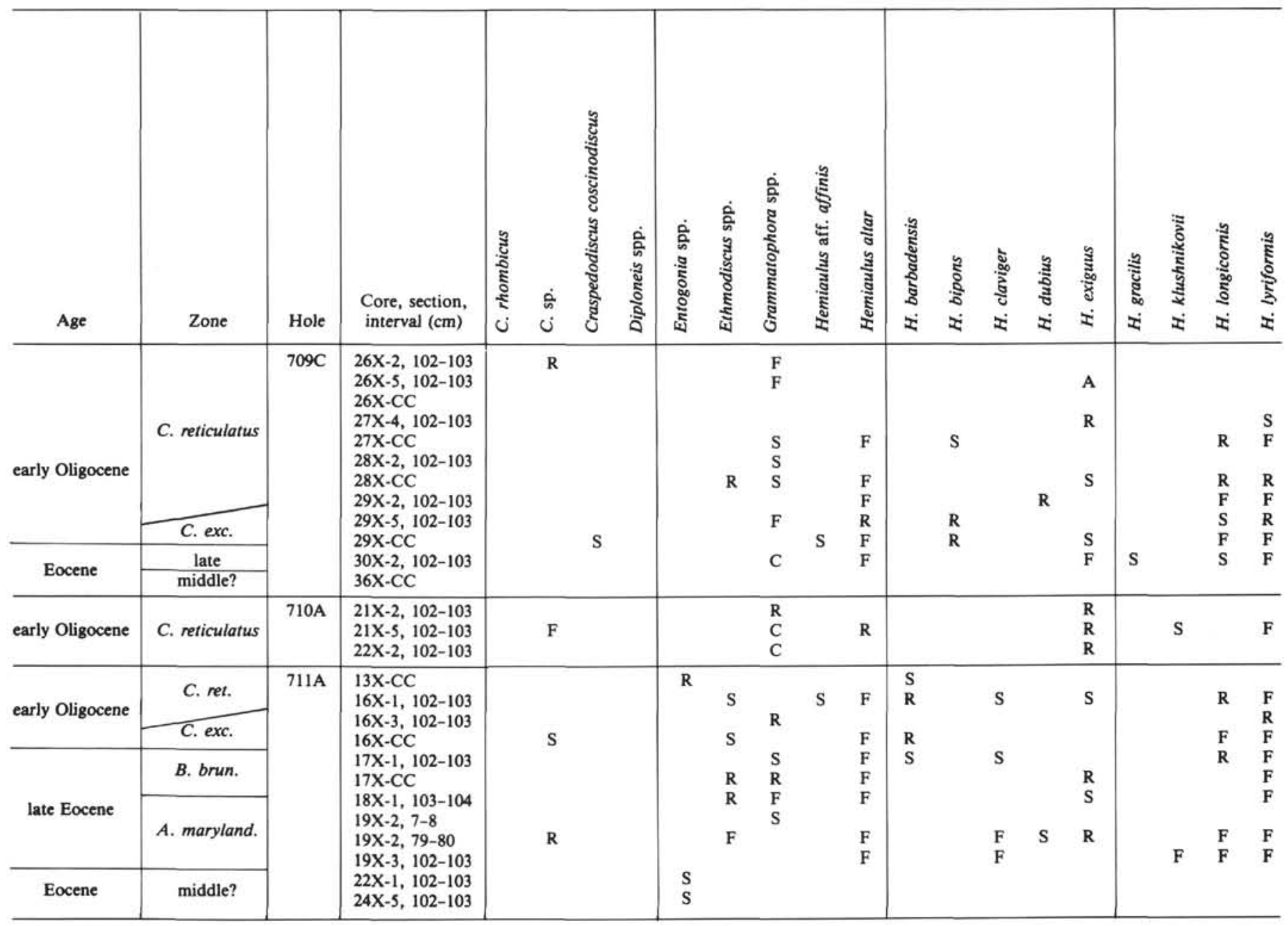

Genus MELOSIRA Agardh (1824)

Melosira architecturalis Brun (1892) in A. Schmidt et al. (1874- )

Plate 1, Figure 8

Synonym. Cyclotella hannae Kanaya (1957), pp. 82-84, pl. 3, figs. 10-14.

Description. A. Schmidt et al. (1874- ), pl. 177, figs. 45-50.

Genus NAVICULA Bory (1822)

Navicula spp.

Remarks. The few specimens found belonging to this genus were not identified to species level.

\section{Genus NEOBRUNIA Kuntze (1894)}

Neobrunia spp.

Remarks. Rare valve fragments presumably belonging to Neobrunia mirabilis were found in the late Oligocene sediments of Site 714.

\section{Genus PARALIA Heiberg (1863) \\ Paralia sulcata (Ehr.) Cleve (1873) \\ Plate 1, Figure 10}

Description. Hustedt (1930), pp. 276-278, figs. 118-120.

Paralia(?) ornata Grunow in Van Heurck (1882)

Description. Van Heurck (1882), pl. 91, figs. 19-21.

Genus PORODISCUS Greville (1863a)

Porodiscus elegans Greville (1863a)

Plate 1, Figure 11

Description. Greville (1863a), p. 64, pl. 4, fig. 1.
Genus PSEUDOPODOSIRA Jousé in Proshkina-Lavrenko (1949)

Pseudosira bella Posnova and Gleser in Gleser and Posnova (1964).

Description. Gleser and Posnova (1964), p. 61, fig. 1.

Pseudopodosira simplex (Jousé) Strelnikova (1974)

Description. Strelnikova (1974), pp. 51-52, pl. 2, figs. 10-11.

Genus PSEUDOTRICERATIUM Grunow (1884)

Pseudotriceratium radiosoreticulatum (Grunow) Jousé in Dzinoridze et al. (1979)

Description. Van Heurck (1883), p. 112, fig. 5; Fenner (1985), p. 735 , fig. 12.11 .

\section{Genus PYXILLA Greville (1865a) \\ Pyxilla prolongata Brun (1893)}

Description. Brun (1893), p. 176, pl. 24, fig. 7.

$$
\text { Genus RHAPHONEIS Ehrenberg (1844b) }
$$

Rhaphoneis(?) immunis Lohmann (1948)

Description. Lohmann (1948), p. 182, pl. 11, fig. 6.

Genus RHIZOSOLENIA Ehrenberg (1841b)

Rhizosolenia hebetata Bailey (1856)

Description. Grunow (1884), p. 44, pl. 5, figs. 48-50.

Rhizosolenia interposita Hajós (1976)

Description. Hajós (1976), p. 827, pl. 21, fig. 8. 
Table 4 (continued).

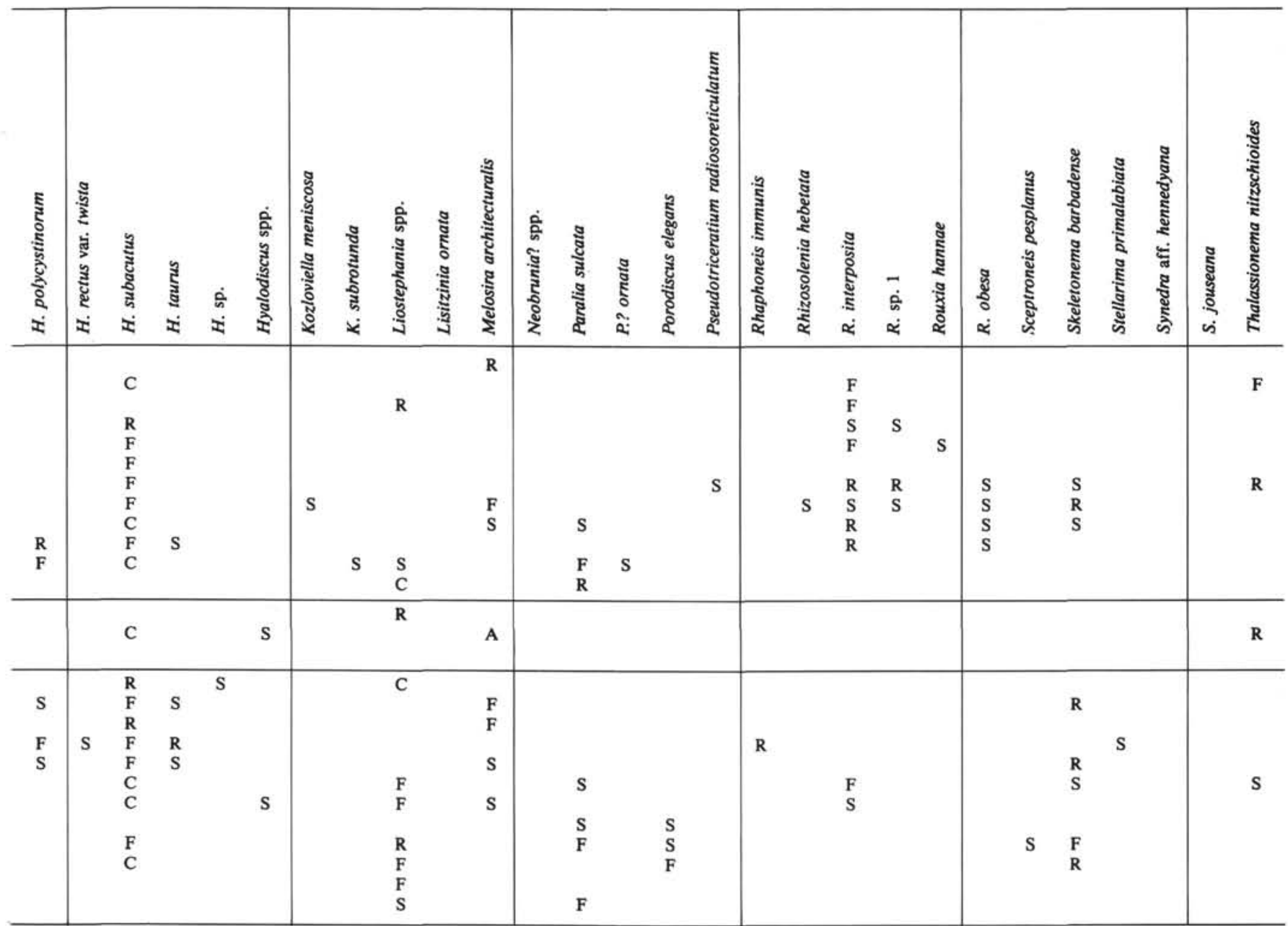

\section{Rhizosolenia sp. 1}

Description. Of this species only the conical valve (calyptra) was found. The valve is coarsely areolated, and small spines are arranged around its truncate top. This species was found in the early Oligocene sediments of Site 709.

Genus RIEDELIA Jousé and Sheshukova-Poretzkaya (1971) Riedelia pacifica Jousé in Jousé and Sheshukova-Poretzkaya (1971)

Description. Jousé and Sheshukova-Poretzkaya (1971), p. 22, pl. 2, figs. 3-4; Gleser and Jousé (1974), p. 60, pl. 3, fig. 11.

Genus ROCELLA Hanna (1930)

Rocella princeps (Jousé) Fenner comb. nov.

Basionym. Coscinodiscus princeps Jousé (1974), p. 350, pl. 3, figs. 8-12.

Description. Jousé (1974), p. 350, pl. 3, figs. 8-12.

$$
\text { Rocella vigilans Fenner (1984a) }
$$

Description. Fenner (1984a), p. 333, pl. 1, fig. 11.

Genus ROSSIELLA Desikachary and Maheshwari (1958)

Rossiella symmetrica Fenner (1984a)

Description. Fenner (1984a), p. 333-334, pl. 1, figs. 2-4.

Genus ROUXIA Brun and Héribaud in Héribaud (1893)

Rouxia hannae Jousé (1974)

Description. Jousé (1974), pp. 349-350, pl. 2, fig. 13.
Rouxia obesa Schrader in Schrader and Fenner (1976)

Description. Schrader and Fenner (1976), p. 997, pl. 24, figs. 5-6.

Genus RUTILARIA Greville (1863b)

Rutilaria sp.

Remarks. Only one specimen of a not-yet-described species belonging to this genus was found. The specimen has a nearly circular outline and coarse areolation.

Genus SCEPTRONEIS Ehrenberg (1844c)

Sceptroneis pesplanus Fenner and Schrader in Schrader and Fenner (1976)

Description. Schrader and Fenner (1976), p. 998, pl. 22, figs. 30-31; pl. 25 , figs. 10-11.

\section{Genus SKELETONEMA Greville (1865b) \\ Skeletonema barbadense Greville (1865b) Plate 1, Figure 5}

Description. Greville (1865b), p. 43, pl. 5, fig. 1.

Genus STELLARIMA Hasle and Sims (1986)

Stellarima primalabiata (Gombos) Hasle and Sims (1986)

Description. Gombos and Ciesielski (1983), p. 606, pl. 9, figs. 1-8.

Genus STEPHANOPYXIS Ehrenberg (1844c)

Stephanopyxis turris (Greville and Arnott) Ralfs in Pritchard (1861)

Description. Hustedt (1930), p. 304, fig. 140; Grunow (1884), p. 87. 


\section{J. FENNER, N. MIKKELSEN}

Table 4 (continued).

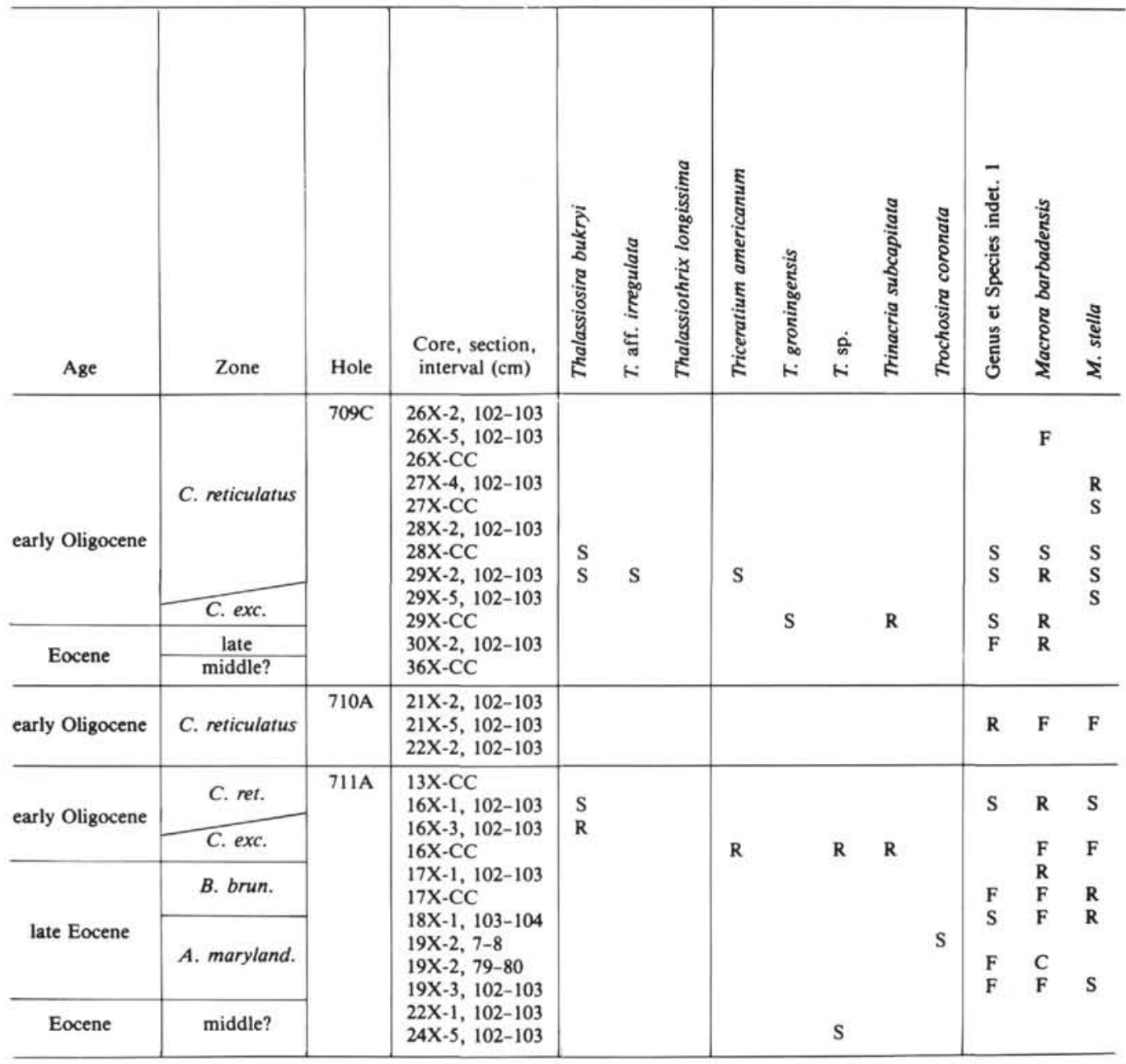

\section{Genus STRANGULONEMA Greville (1865b)}

Strangulonema barbadense Greville (1865b)

Description. Greville (1865b), p. 44, pl. 5, fig. 2 .

Genus SYNEDRA Ehrenberg (1830)

Synedra aff. hennedyana Gregory (1857)

Description. Gregory (1857), p. 532, pl. 14, fig. 108.

Remarks. Fragments of valves similar to this species were only sporadically found.

Synedra jouseana Sheshukova-Poretzkaya (1962)

Description: Sheshukova-Poretzkaya (1962), p. 208, fig. 4; Schrader (1973), p. 710, pl. 23, figs. 21-23, 25, 38.

Genus THALASSIONEMA Grunow in Van Heurck (1881)

Thalassionema nitzschioides (Grunow) Van Heurck (1896)

Description. Van Heurck (1896), p. 319, fig. 75; Hustedt (1932), p. 244, fig. 725 .

\section{Genus THALASSIOSIRA Cleve (1873)}

Thalassiosira bukryi Barron (1983) Plate 1, Figure 4

Description. Barron (1983), p. 511, pl. 4, figs. 1-2; pl. 6, fig. 9; Fenner (1985), p. 739.

Thalassiosira aff. irregulata Schrader and Fenner (1976)

Description. Schrader and Fenner (1976), p. 1002, pl. 20, fig. 13.
Genus THALASSIOTHRIX Cleve and Grunow (1880)

Thalassiothrix longissima Cleve and Grunow (1880) var.

Description. Hustedt (1932), p. 244, figs. 725 and 726.

Remarks. The species occurring in the Oligocene sediments of Leg 115 is fairly delicate, and the areolae are smaller than in $T$. longissima.

\section{Genus TRICERATIUM Ehrenberg (1839)}

Remarks. A multitude of large shallow-water species of this genus were found. Because only single specimens or fragments of the different species occurred, they were not listed as separate species. Among these shallow-water species were Triceratium aff. exornatum Grev., T. westianum Grev., T. rotundatum Grev., T. productum Grev., T. pauperculum Grev., T. venosum Brightwell, T. areolatum Grev., T. zonatum Grev., and, most commonly, fragments of a large species that has valves with a characteristic structure of radiating ribs like $T$. polycystinorum Pantocsek or T. morlandii Grove and Sturt.

\section{Triceratium aff, americanum Ralfs in Pritchard (1861)}

Plate 3, Figure 2

Description. A. Schmidt et al. (1874-), pl. 76, fig. 27 (pl. 76, fig. 28 is in error, see Boyer, 1900 , p. 721 ).

Remarks. The specimens encountered in the Leg 115 material are more coarsely areolated than the specimens illustrated in A. Schmidt et al. (1874-).

\section{Triceratium aff. brachiatum Brightwell (1856)}

$$
\text { Plate 3, Figure } 7
$$

Description. Brightwell (1856), p. 274, pl. 17, fig. 3. 
Triceratium groningensis Reinhold (1937)

Description. Reinhold (1937), p. 126, pl. 20, fig. 9.

Triceratium westianum Greville (1861)

Plate 3, Figures 5-6

Description. Greville (1861), p. 43, pl. 4, fig. 11.

Genus TRINACRIA Heiberg (1863)

Trinacria subcapitata (Grev.) Grunow (1884)

Description. Greville (1863b), p. 234, pl. 10, fig. 20; Grunow (1884), p. 69.

\section{Genus TROCHOSIRA Kitton (1871)}

Trochosira aff. trochlea Hanna (1927)

Description. Hanna (1927), p. 123, pl. 21, figs. 8 and 9.

Remarks. The specimens observed near the Eocene/Oligocene boundary are smaller and more finely areolated than the species described from the middle Eocene by Hanna.

Trochosira coronata Schrader and Fenner (1976)

Description. Schrader and Fenner (1976), p. 1003, pl. 29, figs. 9-11; pl. 35 , figs. $7-13$ and $20-21$.

\section{Genus XANTHIOPYXIS Ehrenberg (1844c) \\ Xanthiopyxis spp.}

Remarks. Under this name are generally listed the resting spores of unknown species, in most cases species belonging to the genus Chaetoceros. In this study different types of resting spores of this genus were not differentiated.

\section{Genera Incertae Sedis}

Genus MACRORA Hanna (1932)

Macrora barbadensis (Deflandre) Bukry (1978)

Description. Bukry (1977), p. 832, pl. 2, figs. 3-8.

$$
\begin{gathered}
\text { Macrora stella (Azpeitia) Hanna (1932) } \\
\text { Plate 4, Figure } 1
\end{gathered}
$$

Description. Hanna (1932), p. 196, pl. 12, fig. 7.

Genus et Species indet. (1)

Remarks. This species is identical with "Genus et species indet. (1)" illustrated in Fenner (1982).

\section{Genus SPERMATOGONIA Leuduger-Fortmorel (1892)}

$$
\text { Spermatogonia spp. }
$$

Remarks. Very rare fragments of species belonging to this genus have been found in the Oligocene sediments recovered during Leg 115.

\section{ACKNOWLEDGMENTS}

The work of J. Fenner was financed by German Science Foundation grant Sa 207/29, and that of N. Mikkelsen by the Danish Natural Science Research Council and the Geological Survey of Denmark.

The authors want to thank captain and crew of the JOIDES Resolution, who drilled the cores. Special thanks go to I. M. Jensen, who typed this manuscript with great patience. C. Geisnaes and B. Rippe made the drawings of the text figures. The English was improved by R. Pickrill, and T. Blanz helped to compile the tables. This paper was reviewed by B. Stabell and H.-J. Schrader.

\section{REFERENCES}

Agardh, C. A., 1824. Systema algarum Adumbravit. Lundae Literis Berlingianis, 37:1-312.

1832. Conspectus Criticus Diatomacearum, Part 4. Lundae Literis Berlingianis, 48-66.

Backman, J., Duncan, R. A., et al., 1988. Proc. ODP, Init. Repts., 115: College Station, TX (Ocean Drilling Program).

Bailey, J. W., 1856. Notice of microscopic forms found in the soundings of the Sea of Kamtschatka - with a plate. Am. J. Sci., 22:1-6.
Barron, J. A., 1975. Late Miocene-early Pliocene marine diatoms from southern California. Paleontographica, Abt. B., 151:97-170. 1983. Latest Oligocene through early middle Miocene diatom biostratigraphy of the eastern tropical Pacific. Mar. Micropaleontol., 7:487-515.

Berggren, W. A., Kent, D. V., and Flynn, J. J., 1985. Jurassic to Paleogene: Part 2. Paleogene geochronology and chronostratigraphy. In Snelling, N. J. (Ed.), The Chronology of the Geologic Record. Geol. Soc. Mem. (London), 10:141-195.

Blow, W. H., 1969. Late middle Eocene to Recent planktonic foraminiferal biostratigraphy. In Brönnimann, P., and Renz, H. H. (Eds.), Proceedings of the First International Conference on Planktonic Microfossils, Genève: Leiden (E. J. Brill), 199-422.

Bory de Saint-Vincent, J.B.M., 1822-1831. Collaborator in "Dictionaire classique d'histoire naturelle (Vol. 17): Atlas et Illustration des Planches," Paris.

Boyer, C. S., 1900. The biddulphoid forms of North American Diatomaceae. Proc. Acad. Nat. Sci. Philadelphia, Pt. 3:685-748.

Brightwell, T., 1856. Further observations on the genus Triceratium with description and figures of new species. Quart. J. Microscop. Sci., 4:272-276.

Brun, J., 1893. Notes sur quelques espèces nouvelles de Diatomées. Le Diatomiste, 1:173-177.

1896. Diatomées Miocène. Le Diatomiste, 2:229-247.

Bukry, D., 1977. Coccolith and silicoflagellate stratigraphy, South Atlantic Ocean, Deep Sea Drilling Project Leg 39. In Perch-Nielsen, K., Supko, P. R., et al., Init. Repts. DSDP, 39: Washington (U.S. Govt. Printing Office). 825-839.

, 1978. Cenozoic silicoflagellate and coccolith stratigraphy, northwestern Atlantic Ocean, Deep Sea Drilling Project Leg 43. In Benson, W. E., Sheridan, R. E., et al., Init. Repts. DSDP, 43: Washington (U.S. Govt. Printing Office), 775-805.

Castracane, A. F., 1886. Report on the scientific results of the voyage of H.M.S. Challenger during the years 1873-76. Botany, No. 2: London (H. M. Stationary Office).

Cleve, P. T., 1873. On diatoms from the Arctic Sea. K. Sven. Vetenskapsakad. Handl., 1:1-28.

Cleve, P. T., and Grunow, A., 1879 (1880). Beiträge zur Kenntnis der arktischen Diatomeen. K. Sven. Vetenskapsakad. Handl., 17:1-121.

Cleve-Euler, A., 1951. Die Diatomeen von Schweden und Finnland. $K$. Sven. Vetenskapsakad. Handl., Fjärde Serien, 2:1-163.

Desikachary, T. V., and Maheshwari, C. L., 1958. Fossil diatoms from Colebrook Island. J. Ind. Bot. Soc., 38:27-41.

Dzinoridze, R. N., Jousé, A. P., and Strelnikova, N. I., 1979. Description of the diatoms. In The history of the microplankton of the Norwegian Sea (on the Deep Sea Drilling materials). Acad. Sci. USSR Zool. Inst., Explorations of the Faunas of the Seas, 23:32-71.

Ehrenberg, C. G., 1830. Beiträge zur Kenntniss der Organisation der Infusorien und ihrer geographischen Verbreitung besonders in Sibirien. Abh. K. Akad. Wiss. Berlin, 1-88.

1837. Die fossilen Infusorien und die lebendige Dammerde. Abh. K. Akad. Wiss. Berlin.

, 1838a. Die Infusionsthierchen als vollkommene Organismen. Ein Blick in das tiefere organische Leben der Natur: Leipzig (Leopold Voss).

, 1838b. Über die Bildung der Kreidefelsen und des Kreidemergels durch unsichtbare Organismen. Abh. K. Akad. Wiss. Berlin, 59-147.

, 1839. Über noch jetzt lebende zahlreiche Thierarten der Kreidebildung und den Organismus der Polythalamien. Abh. K. Akad. Wiss. Berlin, 81-174.

, 1840. Über ausgezeichnete jetzt noch lebende peruanische und mexikanische Meeres-Infusorien, welche mit zur Erläuterung rätselhafter fossiler Formen der Kreidebildung dienen. Ber. Bekanntm. Geeign. K. Preuss. Akad. Wiss., Berlin, 157-162.

, 1841a. Über Verbreitung und Einfluss des mikroskopïschen Lebens in Süd- und Nordamerika. Ber. Bekanntm. Geeign. Verh. K. Akad. Wiss. Berlin, 139-144.

, 1841b (1843). Verbreitung und Einfluss des mikroskopischen Lebens in Süd- und Nordamerika. Abh. K. Akad. Wiss. Berlin, 291-445.

1844a. Einige vorläufige Resultate seiner Untersuchungen der ihm von der Südpolreise des Capitain Ross, so wie von den Herren Schayer und Darwin zugekommenen Materialien über das Verhalten des kleinsten Lebens in den Ozeanen und den grössten bisher zu- 
gänglichen Tiefen des Weltmeeres. Ber. Bekanntm. Geeign. Verh. K. Akad. Wiss. Berlin, 182-207.

1844b. Mitteilung über 2 neue Lager von Gebirgsmassen aus Infusorien als Meeres-Absatz in Nord-Amerika und eine Vergleichung derselben mit den organischen Kreide-Gebilden in Europa und Afrika. Ber. Bekanntm. Geeign. Verh. K. Akad. Wiss. Berlin, 57-97.

$1844 \mathrm{c}$ (1845). Untersuchungen über die kleinsten Lebensformen im Quellenlande des Euphrats und Araxes, so wie über eine an neuen Formen sehr reiche, marine Tripelbildung von den BermudaInseln. Abh. K. Akad. Preuss Akad. Wiss. Berlin, 253-275.

1845. Neue Untersuchnungen über das kleinste Leben als geologisches Moment. Mit kurzer Charakteristik von 10 neuen Genera und 66 neuen Arten. Abh. K. Preuss. Akad. Wiss. Berlin: 53-88.

Fenner, J., 1978. Cenozoic diatom biostratigraphy of the equatorial and southern Atlantic Ocean. In Perch-Nielsen, K., Supko, P. R., et al., Init. Repts. DSDP, 39: Washington (U.S. Govt. Printing Office), 491-624.

1982. Diatoms in the Eocene and Oligocene sediments off NW Africa, their stratigraphic and paleogeographic occurrences [PhD thesis]. Univ. of Kiel, Federal Republic of Germany.

1984a. Eocene-Oligocene planktic diatom stratigraphy in the low latitudes and the high southern latitudes. Micropaleontology, 30:319-342.

1984b. Middle Eocene to Oligocene planktonic diatom stratigraphy from Deep Sea Drilling sites in the South Atlantic, equatorial Pacific, and Indian Ocean. In Hay, W. W., Sibuet, J.-C., et al., Init. Repts. DSDP, 75, Pt. 2: Washington (U.S. Govt. Printing Office), $1245-1271$.

1985. Late Cretaceous to Oligocene planktic diatoms. In Bolli, H. M., Saunders, J. B., and Perch-Nielsen, K. (Eds.), Plankton Stratigraphy: Cambridge (Cambridge Univ. Press), 713-762.

, in press. Taxonomy, stratigraphy, and paleo-oceanographic implications of Paleocene diatoms from ODP Leg 114. In Ciesielski, P. F., Kristoffersen, Y. K., et al., Proc. ODP, Sci. Results, 114, Washington: (U.S. Govt. Printing Office).

Gleser, S. I., and Jousé, A. P., 1974. Diatoms and silicoflagellates in the Eocene of the equatorial Atlantic. In Jousé, A. P. (Ed.), Micropaleontology of Oceans and Seas: Moscow (Acad. Nauk, USSR), 49-62.

Gleser, S. I., and Posnova, A. N., 1964. Diatomeae novae marinae ex eoceno Kazachstaniae occidentalis. Nov. Sist. Nizshikh Rast.: Moscow (Akad. Nauk, USSR), 59-66.

Gombos, A. M., Jr., 1982. Early and middle Eocene diatom evolutionary events. Bacillaria, 5:225-242.

Gombos, A. M., Jr., and Ciesielski, P. F., 1983. Late Eocene to early Miocene diatoms from the southwest Atlantic. In Ludwig, W. J., Krasheninnikov, V. A., et al., Init. Repts. DSDP, 71, Pt. 2: Washington (U.S. Govt. Printing Office), 583-634.

Gregory, W., 1857. On new forms of marine Diatomaceae found in the Firth of Clyde and in Loch Fine. Trans. R. Soc. Edinburgh, 21:473542.

Greville, R. K., 1860. A monograph of the genus Asterolampra, including Asteromphalus and Spatangidium. Trans. Microscop. Soc. London, 8:102-124.

1861. Descriptions of new and rare diatoms. Series I. Trans. Microscop. Soc. London, NS, 9:39-45.

, 1862. On the Asterolamprae of the Barbados deposit. Trans. Microscop. Soc. London, NS, 2:41-58.

, 1863a. Descriptions of new and rare diatoms. Series 9. Trans. Microscop. Soc. London, NS, 11:63-79.

1863b. Descriptions of new and rare diatoms. Series 10. Trans. Microscop. Soc. London, NS, 3:227-240.

, 1865a. Descriptions of new and rare diatoms. Series 14. Trans. Microscop. Soc. London, NS, 13:1-37.

, 1865b. Descriptions of new and rare diatoms, Series 16. Trans. Microscop. Soc. London, NS, 13:43-60.

1866a. Descriptions of new and rare diatoms. Series 19. Trans. Microsc. Soc. London, NS, 14:77-88.

1866b. Descriptions of new and rare diatoms. Series 20. Trans. Microscop. Soc. London, NS, 14:121-130.

Grunow, A., 1884. Die Diatomeen von Franz Josefs-Land. Denkschr. Kaiserl. Akad. Wiss., Math.-Nat. Klasse, Wien, 48:53-112.

Hajós, M., 1976. Upper Eocene and lower Oligocene Diatomaceae, Archaeomonadaceae, and Silicoflagellatae in southwestern Pacific sed- iments, DSDP Leg 29. In Hollister, C. D., Craddock, C., et al., Init. Repts. DSDP, 35: Washington (U.S. Govt. Printing Office), 817884.

Hanna, G. D., 1927. The lowest known Tertiary diatoms in California. J. Paleontol., 1:103-126.

1930. A new genus of silicoflagellata from the Miocene of lower California. J. Paleontol., 4:415-416.

, 1932. The diatoms of Sharktooth Hill, Kern County, California. Proc. Calif. Acad. Sci., Ser. IV, 20:161-263.

Hanna, G. D., and Brigger, A. L., 1970. Observations on Liostephania. Beih. Nova Hedwigia, 31:89-101.

Hanna, G. D., and Grant, W. M., 1926. Expedition to the Revilla Gigedo Islands, Mexico, in 1925. II. Miocene marine diatoms from Maria Madre Islands, Mexico. Proc. Calif. Acad. Sci., Ser. VI, 15: $115-193$.

Hart, T. J., 1935. On the diatoms of the skin film of whales, and their possible bearing on problems of whale movements. Discovery Repts., 10:247-282.

Hasle, G. R., and Sims, P. A., 1986. The diatom genera Stellarima and Symbolophora with comments on the genus Actinoptychus. Br. Phycol. J., 21:97-114.

Heiberg, P.A.C., 1863. Conspectus Criticus Diatomacearum Danicarum: Kjøbenhavn (Wilhelm Priors Forlag).

Héribaud, J., 1893. Les Diatomées d'Auvergne: Paris (Lib. Sci. Natur.).

Hustedt, F., 1930. Die Kieselalgen Deutschlands, Österreichs und der Schweiz, mit Berücksichtigung der übrigen Länder Europas sowie der angrenzenden Meeresgebiete. In Rabenhorst, L. (Ed.), Kryptogamen-Flora von Deutschland, Österreich und der Schweiz (Vol. 7): Leipzig (Akad. Verlag), 1-920.

1932. Die Kieselalgen Deutschlands, Osterreichs und der Schweiz unter Berücksichtigung der übrigen Länder Europas sowie der angrenzenden Meeresgebiete, Part 2(2). In Rabenhorst, L. (Ed.), Kryptogamen-Flora von Deutschland, Österreich und der Schweiz (Vol. 7): Leipzig (Akad. Verlag), 737-845.

Jousé, A. P., 1974. Diatoms in Oligocene-Miocene biostratigraphic zones of the tropical areas of the Pacific Ocean. Beih. Nova Hedwigia, 45: 333-364.

1978. Novii iskopaemii rod diatomei Lisitzinia (Bacillariophyta). Morsk. Mikropal. Akad. Nauk USSR, Moscow, 47-48.

Jousé, A. P., and Sheshukova-Poretzkaya, V. S., 1971. Genus novum Riedelia Jousé et Sheshukova-Poretzkaya (Bacillariophyta). Nov. System. Plant. non Vascular., 8:19-25.

Kanaya, T., 1957. Eocene diatom assemblages from the "Kellogg" and "Sidney" shales, Mt. Diablo Area, California. Sci. Rep. Tohoku Univ., Ser. 2 (Geol.), 28:1-124.

Karsten, G., 1905. Wissenschaftliche Ergebnisse der Deutschen TiefseeExpedition auf dem Dampfer "Valdivia" 1898-99, herausgegeben von Carl Chun. Bd. 2, Tl. 3. G. Karsten. Das Phytoplankton des Antarktischen Meeres nach dem Material der Deutschen Tiefsee-Expedition, 1898-99: 1-136.

1928. Abteilung Bacillariophyta (Diatomeae). In Engler, A., and Prantl, K. (Eds.), Die natürlichen Pflanzenfamilien (Aufl. 2, Bd. 2), Peridineae (Dinofagellatae), Diatomeae (Bacillariophyta): Leipzig (Wilhelm Engelmann), 105-345.

Kitton, F., 1871. On diatomaceous deposits from Jutland. J. Quekett Microsc. Club, 2:99-102, 168-171.

Kuntze, O., 1894. Nomenclatur-Studien. Bull. de l'Herbar Boisser, 2: 456-498.

Leuduger-Fortmorel, G., 1892. Diatomées de la Malaisie. Ann. Jardin Bot. Buitenzorg, 11:1-60.

Loeblich, A. R., Loeblich, L. A., Tappan, H., and Loeblich, A. R., Jr., 1968. Annotated index of fossil and recent silicoflagellates and ebridians with descriptions and illustrations of validly proposed Taxa. Mem. Geol. Soc. Am., 106:1-319.

Lohmann, K. E., 1948. Middle Miocene diatoms from the Hammond Well: Cretaceous and Tertiary subsurface geology. Maryland Dept. Mines Geol. Bull., 2:151-186.

McKenzie, D. P., and Sclater, J. G., 1971. The evolution of the Indian Ocean since the late Cretaceous. Geophys. J. R. Astron. Soc., 24: 437-528.

Mills, F. W., 1933-1935. An Index of the Genera and Species of the Diatomaceae and Their Synonyms, 1816-1932: London (Wheldon and Wesley): 1-526 (1933), 527-1444 (1934), 1444-1726 (1935).

Okada, H., and Bukry, D., 1980. Supplementary modification and introduction of code numbers to the low-latitude coccolith biostrati- 
graphic zonation (Bukry, 1973; 1975). Mar. Micropaleontol., 5:321325.

Pantocsek, J., 1886. Beiträge zur Kenntnis der fossilen Bacillarien Ungarns, Bd. 1: Marine Bacillarien: Berlin (A. Junk).

Pritchard, A., 1852. A History of Infusoria Living and Fossil: London (Whittaker).

, 1861. History of Infusoria, including the Desmidiaceae and Diatomaceae, British and Foreign (4th ed.): London (Whittaker and Co.).

Proshkina-Lavrenko, A. I., 1949. Diatomovyi Analis. Bot. Inst. Akad. Nauk USSR, 2:210-224.

Rattray, J., 1889. A revision of the genus Coscinodiscus and some allied genera. Proc. R. Soc. Edinburgh, 16:449-692.

Reinhold, T., 1937. Fossil diatoms of the Neogene of Java and their zonal distribution. Verh. Geol. Mijnbouwkd. Genoot. Ned. Kolon., Geol. Ser., 12:1-132.

Ross, R., and Sims, P. A., 1980. Syringidium Ehrenb., Dextradonator Ross \& Sims, nov. gen. and Abas Ross \& Sims, nov. gen. Bacillaria, 3:115-127.

1985. Some genera of the Biddulphiaceae (diatoms) with interlocking linking spines. Bull. Br. Mus. Nat. Hist. (Bot.), 13:277381.

Schmidt, A., et al., 1874- . Atlas der Diatomaceen-Kunde: Leipzig and Berlin (O. R. Reisland). [Begun by Schmidt, A., continued by Schmidt, M., Fricke, F., Heiden, H, Müller, O., and Hustedt, F.]

Schrader, H.-J., 1973. Cenozoic diatoms from the northeast Pacific, Leg 18. In Kulm, L. D., von Huene, R., et al., Init. Repts. DSDP, 18: Washington (U.S. Govt. Printing Office), 673-797.

1974. Cenozoic planktonic diatom stratigraphy of the tropical Indian Ocean. In Fisher, R. L., Bunce, E. T., et al., Init. Repts. DSDP, 24: Washington (U.S. Govt. Printing Office), 887-967.

Schrader, H.-J., and Fenner, J., 1976. Norwegian Sea Cenozoic diatom biostratigraphy and taxonomy. In Talwani, M., Udintsev, G., et al., Init. Repts. DSDP, 38: Washington (U.S. Govt. Printing Office), 921-1099.
Sheshukova-Poretzkaya, V. S., 1962. Novie i redkie Bacillariophyta iz diatomovoi suiti Sakhalina. Uch. Zap. Ser. Biol. Nauk (Leningrad Univ.), 49:203-211.

Sheshukova-Poretzkaya, V. S., and Gleser, S. I., 1962. Bacillariophyta, Silicoflagellata and Ebriideae from Maikop series deposits (River Shibik, Krasnodar Region). Uch. Zap. Ser. Biol. Nauk (Leningrad Univ.), 49:171-202. 1964. Diatomeae marinae novae e Paleogeno Ucrainiae. Nov. Sist. Nizshikh Rast. Moscow and Leningrad (Akad. Nauk, USSR), 78-92.

Simonsen, R., 1974. The diatom plankton of the Indian Ocean Expedition of $R / V$ "Meteor" 1964-1965. "Meteor" Forschungsergeb., Reihe D, 19:1-107. 9-71.

, 1979. The diatom system: ideas on phylogeny. Bacillaria, 2:

Strelnikova, N. I., 1974. Diatomei pozdnego mela (Late Cretaceous diatoms of western Siberia). Acad. Nauk USSR, 8:1-202.

Thwaites, G.H.K., 1848. Further observations on the Diatomaceae with descriptions of new genera and species. Annals. Mag. Nat. Hist., Ser. 2, 1:161-172.

Van Heurck, H., 1880-1885. Synopsis des Diatomeés de Belgique. Atlas, pl. 1-30 (1880), pl. 31-77 (1881), pl. 78-103 (1882); pl. 104-132 (1883); pl. A.B.C (1885): Anvers (Ducaju et Cie). Sons).

Van Landingham, S. L., 1967-1979. Catalogue of the Fossil and Recent Genera and Species of Diatoms and their Synonyms: J. Cramer, Lehre. [A revision of F. W. Mills, "An index to the genera and species of the Diatomaceae and their synonyms."]

Date of initial receipt: 20 July 1989

Date of acceptance: 15 January 1990

Ms 115B-207 
Table 5. Occurrence charts of Paleogene diatom species in Holes 713A, 714A, and DSDP Hole 219 from the Chagos-Laccadive Ridge, and Site 236 in the abyssal plain northeast of the Seychelles Bank.

\begin{tabular}{|c|c|c|c|c|c|c|c|c|c|c|c|c|c|c|c|c|c|c|c|c|c|}
\hline Age & Zone & Hole & $\begin{array}{l}\text { Core, section } \\
\text { interval }(\mathrm{cm})\end{array}$ & 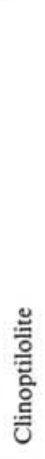 & $\frac{5}{2}$ & $\frac{\bar{g}}{0}$ & 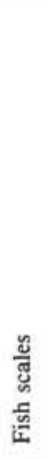 & 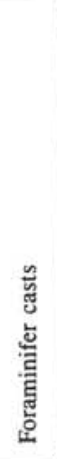 & 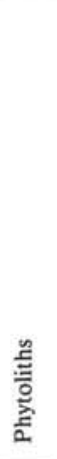 & 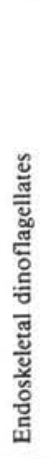 & 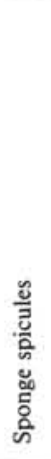 & 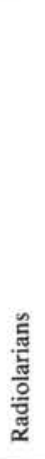 & 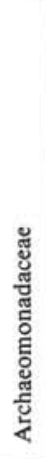 & 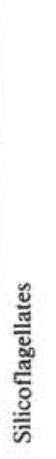 & 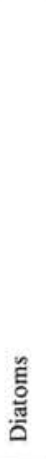 & 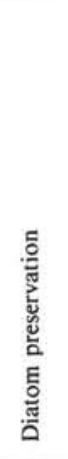 & 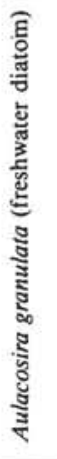 & 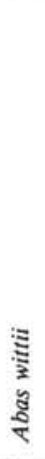 & 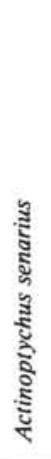 & 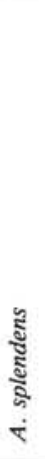 & 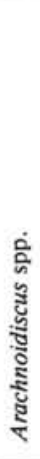 \\
\hline Eocene & middle & $713 \mathrm{~A}$ & $\begin{array}{l}\text { 6R-3, 102-103 } \\
\text { 7R-3, 103-104 } \\
\text { 7R-5, 103-104 } \\
\text { 8R-1, 102-103 } \\
\text { 8R-3, 100-101 } \\
\text { 8R-CC } \\
\text { 9R-1, 102-103 }\end{array}$ & $\mathbf{R}$ & $\begin{array}{l}\text { F } \\
\text { C } \\
\text { A } \\
\text { R } \\
\text { R } \\
\text { S }\end{array}$ & & $\begin{array}{l}\mathrm{S} \\
\mathrm{S} \\
\mathrm{S} \\
\mathrm{S} \\
\mathrm{S}\end{array}$ & $\begin{array}{l}\mathrm{F} \\
\mathrm{F} \\
\mathrm{F} \\
\mathrm{F} \\
\mathrm{F} \\
\mathrm{F} \\
\mathrm{R}\end{array}$ & $\begin{array}{l}\mathrm{R} \\
\mathrm{S} \\
\mathrm{S}\end{array}$ & & $\begin{array}{l}\text { C } \\
\text { C } \\
\text { C } \\
\text { C } \\
\text { C } \\
\text { A } \\
\text { A }\end{array}$ & $\begin{array}{l}\text { D } \\
\text { D } \\
\text { D } \\
\text { A } \\
\text { D } \\
\text { A } \\
\text { A }\end{array}$ & $\begin{array}{l}\mathrm{R} \\
\mathrm{R} \\
\mathrm{S} \\
\mathrm{R} \\
\mathrm{R}\end{array}$ & & $\begin{array}{l}\mathrm{R} \\
\mathrm{R} \\
\mathrm{R} \\
\mathrm{R} \\
\mathrm{R} \\
\mathrm{R} \\
\mathrm{C} \\
\end{array}$ & $\begin{array}{l}\mathrm{P} \\
\mathrm{P} / \mathrm{M} \\
\mathrm{P} \\
\mathrm{P} \\
\mathrm{P} \\
\mathrm{P} / \mathrm{M} \\
\mathrm{P} / \mathrm{M} \\
\end{array}$ & & $\begin{array}{l}\text { A } \\
\text { F } \\
\text { F } \\
\\
\text { R } \\
\text { F } \\
\text { F } \\
\end{array}$ & $\mathbf{R}$ & $\mathrm{S}$ & $\begin{array}{l}\mathrm{F} \\
\mathrm{F} \\
\mathrm{F} \\
\mathrm{F} \\
\mathrm{F} \\
\mathrm{F} \\
\mathrm{F}\end{array}$ \\
\hline late Oligoc. & B. veniam. & $714 \mathrm{~A}$ & $\begin{array}{l}22 X-1,102-103 \\
22 X-3,102-103 \\
22 X-C C \\
23 X-1,102-103 \\
23 X-3,102-103 \\
23 X-C C \\
24 X-1,102-103 \\
24 X-C C\end{array}$ & & $\mathrm{~s}$ & & $\begin{array}{l}\mathrm{R} \\
\mathrm{S} \\
\mathrm{S}\end{array}$ & $\begin{array}{l}\mathrm{F} \\
\mathrm{R} \\
\mathrm{R} \\
\mathrm{R} \\
\mathrm{R} \\
\mathrm{R} \\
\mathrm{R} \\
\mathrm{S}\end{array}$ & $S$ & $\begin{array}{l}\mathrm{S} \\
\mathrm{S}\end{array}$ & $\begin{array}{l}\text { C } \\
\text { A } \\
\text { A } \\
\text { A } \\
\text { A } \\
\text { A } \\
\text { D } \\
\text { D }\end{array}$ & $\begin{array}{l}\text { D } \\
\text { A } \\
\text { A } \\
\text { A } \\
\text { A } \\
\text { C } \\
\text { C } \\
\text { R }\end{array}$ & $\mathbf{S}$ & $\mathrm{R}$ & $\begin{array}{l}\text { S } \\
R \\
F \\
S \\
R \\
F \\
S \\
S\end{array}$ & $\begin{array}{c}\mathrm{P} \\
\mathrm{P} \\
\mathrm{P} / \mathrm{M} \\
\mathrm{P} \\
\mathrm{P} \\
\mathrm{P} / \mathrm{M} \\
\mathrm{P} \\
\mathrm{P}\end{array}$ & $\mathbf{R}$ & & & & $\begin{array}{l}\mathrm{C} \\
\mathrm{F} \\
\mathrm{C} \\
\mathrm{F} \\
\mathrm{R} \\
\mathrm{R}\end{array}$ \\
\hline late Eocene? & & 236 & $28-1,46-48$ & & & & & & & & A & $\mathrm{F}$ & & & $\mathrm{S}$ & $\mathrm{P}$ & & & & & \\
\hline Eocene & $\begin{array}{l}\text { late } \\
\text { middle }\end{array}$ & 219 & $\begin{array}{l}17-3,61-66 \\
17-4,61-66 \\
17-4,102-106 \\
17-5,41-46 \\
17-5,61-63 \\
18-1,93-98 \\
18-2,61-66 \\
18-4,61-66 \\
19-1,58-63\end{array}$ & $\begin{array}{l}\text { C } \\
\text { S } \\
\text { S } \\
\text { C } \\
\text { F } \\
\text { C } \\
\text { F } \\
\text { R } \\
\text { C }\end{array}$ & & & & & S & & $\begin{array}{l}\text { A } \\
\text { C } \\
\text { C } \\
\text { C } \\
\text { C } \\
\text { C } \\
\text { C } \\
\text { C } \\
\text { F }\end{array}$ & $\begin{array}{l}\text { C } \\
\text { A } \\
\text { A } \\
\text { A } \\
\text { A } \\
\text { C } \\
\text { A } \\
\text { C } \\
\text { F }\end{array}$ & $\begin{array}{l}\mathrm{R} \\
\mathrm{R} \\
\mathrm{R} \\
\mathrm{R} \\
\mathrm{R} \\
\mathrm{F} \\
\mathrm{F} \\
\mathrm{F} \\
\mathrm{F}\end{array}$ & & $\begin{array}{l}R \\
S \\
S \\
S \\
S \\
S \\
S \\
S \\
S \\
S\end{array}$ & $\begin{array}{l}\mathrm{P} \\
\mathrm{P} \\
\mathrm{P} \\
\mathrm{P} \\
\mathrm{P} \\
\mathrm{P} \\
\mathrm{P} \\
\mathrm{P} \\
\mathrm{P}\end{array}$ & & & & & $\mathrm{S}$ \\
\hline
\end{tabular}

Note: For explanation of symbols for diatom preservation and abundance, see "Methods" section, this chapter. 
Table 5 (continued).

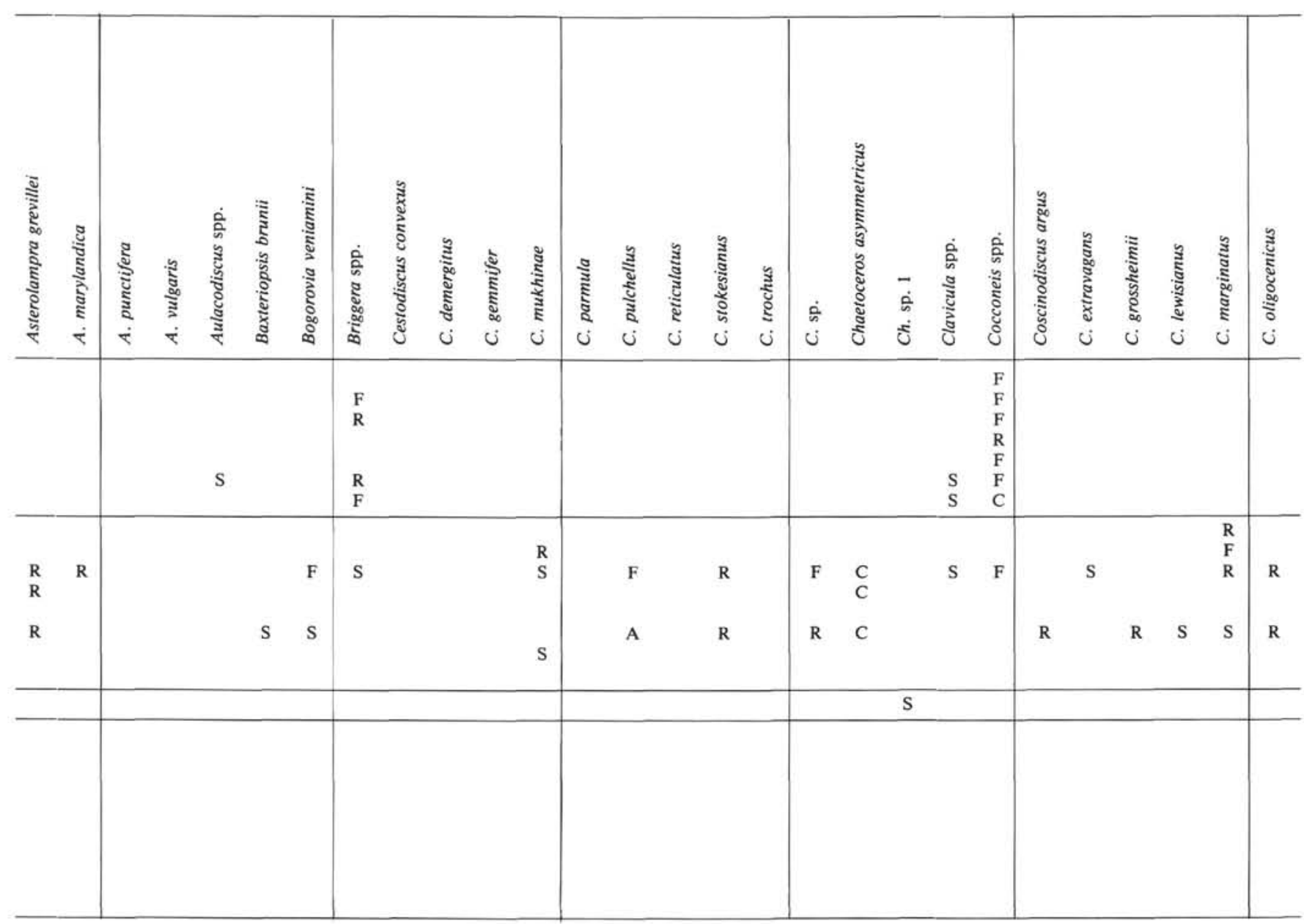


Table 5 (continued).

\begin{tabular}{|c|c|c|c|c|c|c|c|c|c|c|c|c|c|c|c|c|c|c|c|c|c|}
\hline Age & Zone & Hole & $\begin{array}{l}\text { Core, section } \\
\text { interval }(\mathrm{cm})\end{array}$ & 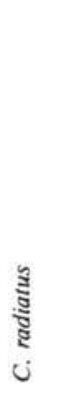 & 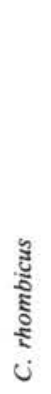 & $\begin{array}{l}2 \\
0 \\
0\end{array}$ & 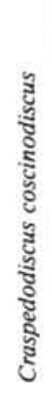 & 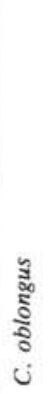 & 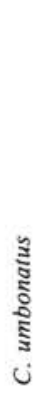 & 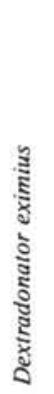 & 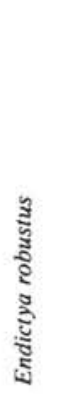 & 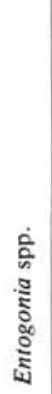 & 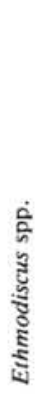 & 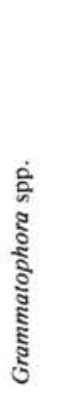 & 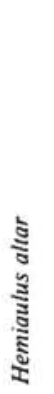 & 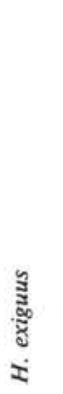 & 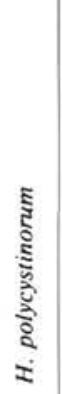 & 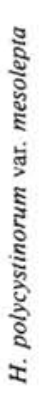 & 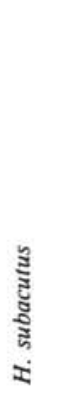 & $\begin{array}{l}\text { ב̃ } \\
\text { ड̃ } \\
=\end{array}$ & 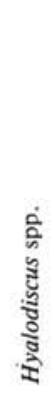 \\
\hline Eocene & middle & $713 \mathrm{~A}$ & $\begin{array}{l}\text { 6R-3, 102-103 } \\
\text { 7R-3, 103-104 } \\
\text { 7R-5, 103-104 } \\
\text { 8R-1, 102-103 } \\
\text { 8R-3, 100-101 } \\
\text { 8R-CC } \\
\text { 9R-1, 102-103 }\end{array}$ & & & S & & $\mathrm{S}$ & $\begin{array}{l}\mathrm{C} \\
\mathrm{F} \\
\mathrm{C} \\
\mathrm{C} \\
\mathrm{C} \\
\mathrm{F} \\
\mathrm{C}\end{array}$ & $\mathrm{S}$ & & $\begin{array}{l}\mathrm{R} \\
\mathrm{F} \\
\mathrm{F} \\
\mathrm{R} \\
\mathrm{R} \\
\mathrm{F} \\
\mathrm{F}\end{array}$ & $\begin{array}{l}\mathrm{F} \\
\mathrm{C} \\
\mathrm{C} \\
\mathrm{C} \\
\mathrm{F}\end{array}$ & $\begin{array}{l}\mathrm{F} \\
\\
\mathrm{R} \\
\mathrm{R} \\
\mathrm{S}\end{array}$ & & & & $\mathrm{S}$ & & & $\begin{array}{l}\mathrm{R} \\
\mathrm{R} \\
\mathrm{S} \\
\mathrm{S}\end{array}$ \\
\hline late Oligoc. & B. veniam. & $714 \mathrm{~A}$ & $\begin{array}{l}22 X-1,102-103 \\
22 X-3,102-103 \\
22 X-C C \\
23 X-1,102-103 \\
23 X-3,102-103 \\
23 X-C C \\
24 X-1,102-103 \\
24 X-C C\end{array}$ & $\mathrm{~S}$ & F & & $\begin{array}{l}\mathrm{F} \\
\mathrm{R} \\
\mathrm{F}\end{array}$ & & & & $\mathrm{R}$ & & $\begin{array}{l}\text { F } \\
\text { F }\end{array}$ & $\begin{array}{l}\text { F } \\
\text { D } \\
\text { A } \\
\text { C } \\
\text { D } \\
\text { F } \\
\text { R } \\
\text { S }\end{array}$ & $\mathrm{F}$ & $\mathrm{s}$ & & & $\mathrm{F}$ & & \\
\hline late Eocene? & & 236 & $28-1,46-48$ & & & & & & & & & & & & & & & & & & \\
\hline Eocene & $\begin{array}{l}\text { late } \\
\text { middle }\end{array}$ & 219 & $\begin{array}{l}17-3,61-66 \\
17-4,61-66 \\
17-4,102-106 \\
17-5,41-46 \\
17-5,61-63 \\
18-1,93-98 \\
18-2,61-66 \\
18-4,61-66 \\
19-1,58-63\end{array}$ & & & & & & & & & & & $\begin{array}{l}\mathrm{C} \\
\mathrm{C} \\
\mathrm{R} \\
\mathrm{S} \\
\mathrm{R} \\
\mathrm{S}\end{array}$ & & & & & & & \\
\hline
\end{tabular}


Table 5 (continued).

\begin{tabular}{|c|c|c|c|c|c|c|c|c|c|c|c|c|c|c|c|c|c|c|c|c|c|c|c|c|c|c|c|}
\hline 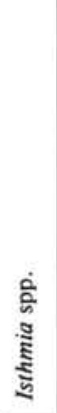 & 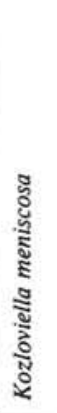 & 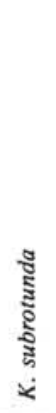 & 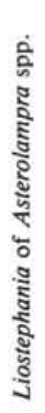 & 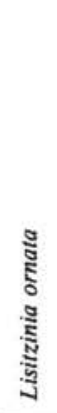 & 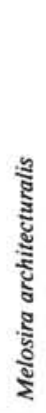 & 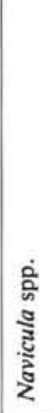 & 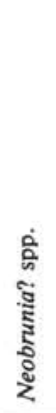 & 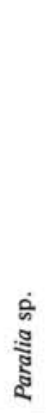 & 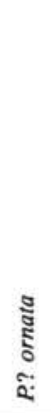 & 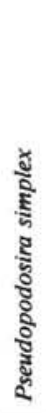 & $\begin{array}{l}\text { ปँ̃ } \\
\text { Q }\end{array}$ & 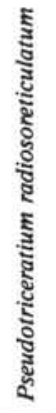 & 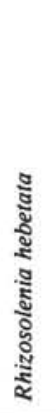 & 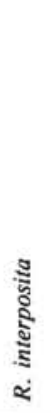 & $\begin{array}{l}\overline{\dot{n}} \\
\dot{\alpha}\end{array}$ & 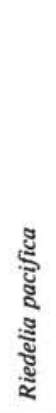 & 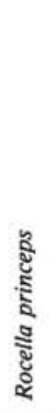 & 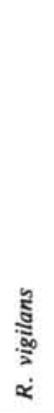 & 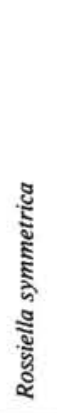 & 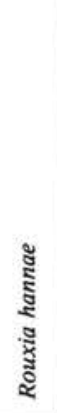 & 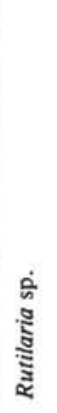 & 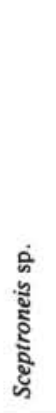 & 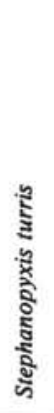 &  & 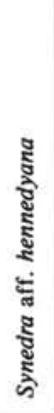 & 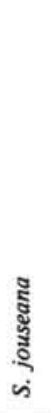 & 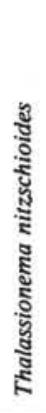 \\
\hline $\begin{array}{l}\mathrm{R} \\
\mathrm{S} \\
\mathrm{F}\end{array}$ & & & $\begin{array}{l}\mathrm{C} \\
\mathrm{F} \\
\mathrm{C} \\
\mathrm{R} \\
\mathrm{F} \\
\mathrm{F}\end{array}$ & & $\begin{array}{l}\text { R } \\
\text { F } \\
\text { F } \\
\text { F }\end{array}$ & $\begin{array}{l}\mathrm{S} \\
\mathrm{S}\end{array}$ & & $\begin{array}{l}\text { C } \\
\text { A } \\
\text { C } \\
\text { A } \\
\text { A } \\
\text { D } \\
\text { A }\end{array}$ & $\begin{array}{l}\mathrm{R} \\
\mathrm{F}\end{array}$ & $\begin{array}{l}\text { F } \\
F \\
F \\
F \\
C \\
\text { C }\end{array}$ & $\mathbf{S}$ & & & $\mathbf{R}$ & & $\mathrm{S}$ & & & & & $\mathrm{S}$ & $\begin{array}{l}\mathrm{R} \\
\mathrm{S} \\
\mathrm{S}\end{array}$ & $\mathbf{S}$ & $\begin{array}{l}\mathbf{S} \\
\mathrm{S}\end{array}$ & & & \\
\hline & $\mathrm{S}$ & & & R & $\mathbf{F}$ & & $\begin{array}{l}\mathbf{R} \\
\mathbf{R}\end{array}$ & $\begin{array}{l}F \\
F\end{array}$ & & & & S & S & $\mathrm{S}$ & & & $\mathbf{R}$ & $\begin{array}{l}\mathbf{F} \\
\mathrm{F} \\
\mathrm{C}\end{array}$ & F & S? & & $\begin{array}{l}\mathrm{S} \\
\mathrm{S}\end{array}$ & & & & $\begin{array}{l}\mathrm{R} \\
\mathrm{C} \\
\mathrm{F} \\
\mathrm{F}\end{array}$ & R \\
\hline & & & $\mathrm{S}$ & & & & & $\mathrm{S}$ & & & & & & & & & & & & & & & & & & & \\
\hline & & & $\begin{array}{l}\text { S } \\
\text { S } \\
\text { R } \\
\text { S } \\
\text { S }\end{array}$ & & & & & $\begin{array}{l}\mathrm{S} \\
\mathrm{S} \\
\mathrm{S} \\
\mathrm{R} \\
\mathrm{R} \\
\mathrm{R} \\
\mathrm{F} \\
\mathrm{R}\end{array}$ & & & & & & & & & & & & & & & & & & & \\
\hline
\end{tabular}


Table 5 (continued).

\begin{tabular}{|c|c|c|c|c|c|c|c|c|c|c|c|c|c|}
\hline Age & Zone & Hole & $\begin{array}{l}\text { Core, section } \\
\text { interval }(\mathrm{cm})\end{array}$ & 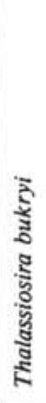 & $\begin{array}{l}\dot{2} \\
\text { के }\end{array}$ & 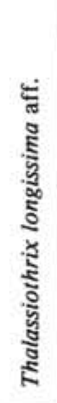 & 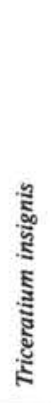 & 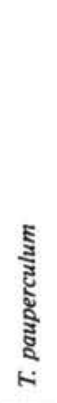 & 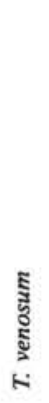 & 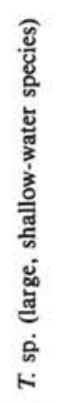 & 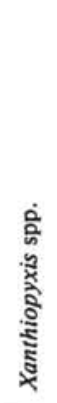 & 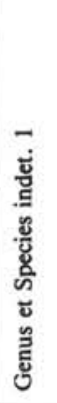 & 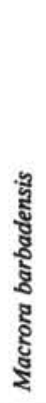 \\
\hline Eocene & middle & $713 \mathrm{~A}$ & $\begin{array}{l}\text { 6R-3, 102-103 } \\
\text { 7R-3, 103-104 } \\
\text { 7R-5, 103-104 } \\
\text { 8R-1, 102-103 } \\
\text { 8R-3, 100-101 } \\
\text { 8R-CC } \\
\text { 9R-1, 102-103 }\end{array}$ & & & & $\mathrm{S}$ & & 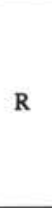 & $\begin{array}{l}\mathrm{C} \\
\mathrm{C} \\
\mathrm{C} \\
\mathrm{C} \\
\mathrm{F} \\
\mathrm{C}\end{array}$ & F & $\mathrm{S}$ & $\begin{array}{l}\mathrm{F} \\
\mathrm{S}\end{array}$ \\
\hline late Oligoc. & B. veniam. & $714 \mathrm{~A}$ & $\begin{array}{l}22 X-1,102-103 \\
22 X-3,102-103 \\
22 X-C C \\
23 X-1,102-103 \\
23 X-3,102-103 \\
23 X-C C \\
24 X-1,102-103 \\
24 X-C C\end{array}$ & & $\mathbf{R}$ & $\begin{array}{l}\text { F } \\
\text { F }\end{array}$ & & $\mathrm{s}$ & & $\begin{array}{l}\mathbf{R} \\
\mathrm{F}\end{array}$ & $\begin{array}{l}\mathbf{F} \\
\mathbf{R} \\
\mathrm{F}\end{array}$ & & \\
\hline late Eocene? & & 236 & $28-1,46-48$ & & & & & & & & & & \\
\hline Eocene & $\begin{array}{l}\text { late } \\
\text { middle }\end{array}$ & 219 & $\begin{array}{l}17-3,61-66 \\
17-4,61-66 \\
17-4,102-106 \\
17-5,41-46 \\
17-5,61-63 \\
18-1,93-98 \\
18-2,61-66 \\
18-4,61-66 \\
19-1,58-63\end{array}$ & & & $\mathrm{~s}$ & & & & & $\mathrm{~S}$ & & \\
\hline
\end{tabular}


shelf - upper slope

with admixture of near-shore material

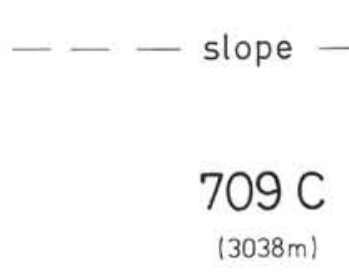

$707 \mathrm{~A}, \mathrm{C}$

(1541m)

$709 \mathrm{C}$
$(3038 \mathrm{~m})$

$711 \mathrm{~A}$

$(4428 \mathrm{~m})$
Eocene-Oligocene water depth

present water depth

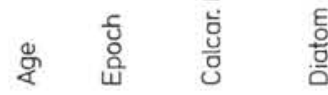
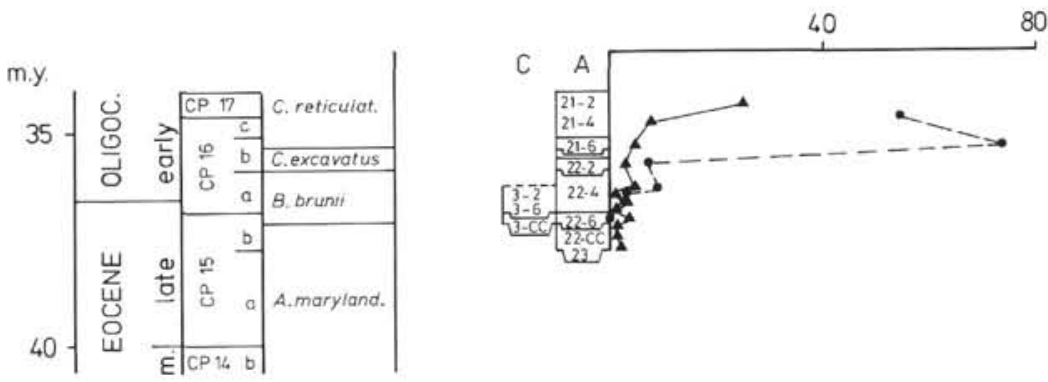

$80 \%$

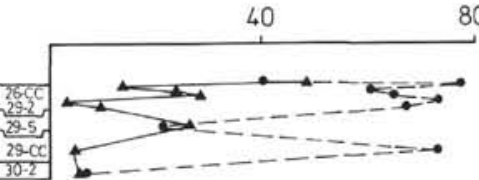

$80 \%$
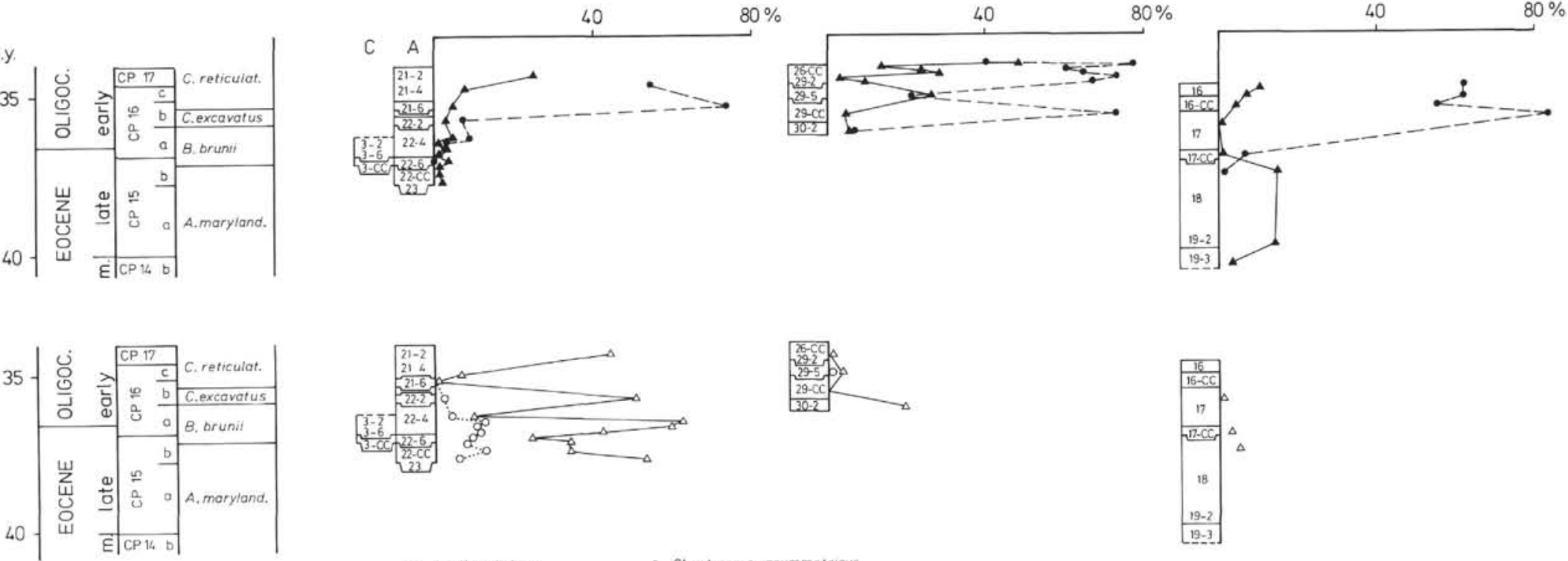

$$
\text { - benthic diatoms - Chaetoceros asymmetricus }
$$$$
\triangle \text { Grammatophora spp } \quad \text { Cestodiscus spp }
$$

Figure 3. Summary diagram with ranges of stratigraphically important diatom species for the late Eocene to Oligocene in the western Indian Ocean. Diatoms are absent or poorly preserved in hatched areas. 


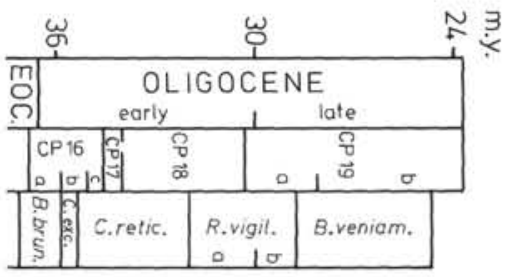

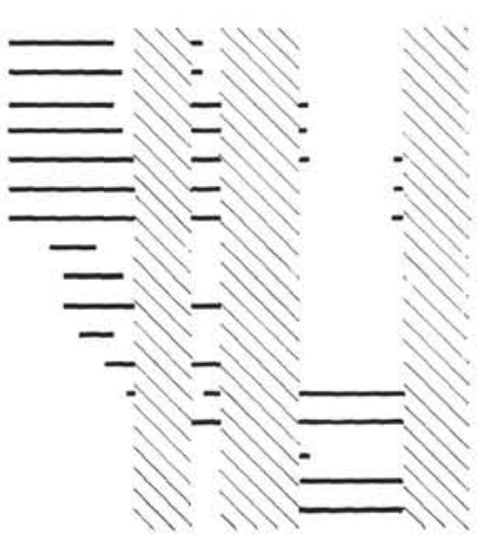

Age

Epochs

Calcar. Nannof Zones

Diatom Zones

Skeletonema barbadense

Hemiqulus lyriformis

Baxteriopsis brunii

Hemiaulus altar

Hemiaulus subacutus

Melosira architecturalis

Asterolampra marylandica

Hemiaulus taurus

Coscinodiscus excavatus

Cestodiscus gemmifer

C. reticulatus

C. parmula

S. jouseana

Rocella vigilans

Lisitzinia ornato

Coscinodiscus rhombicus

Bogorovia veniamini

Figure 4. Percent abundance of selected ecological indicator species and species groups of diatoms in the latest Eocene to early Oligocene sediments of three sites on the northern slopes of the Mascarene Plateau and Madingley Rise. The sites are arranged by water depth. 

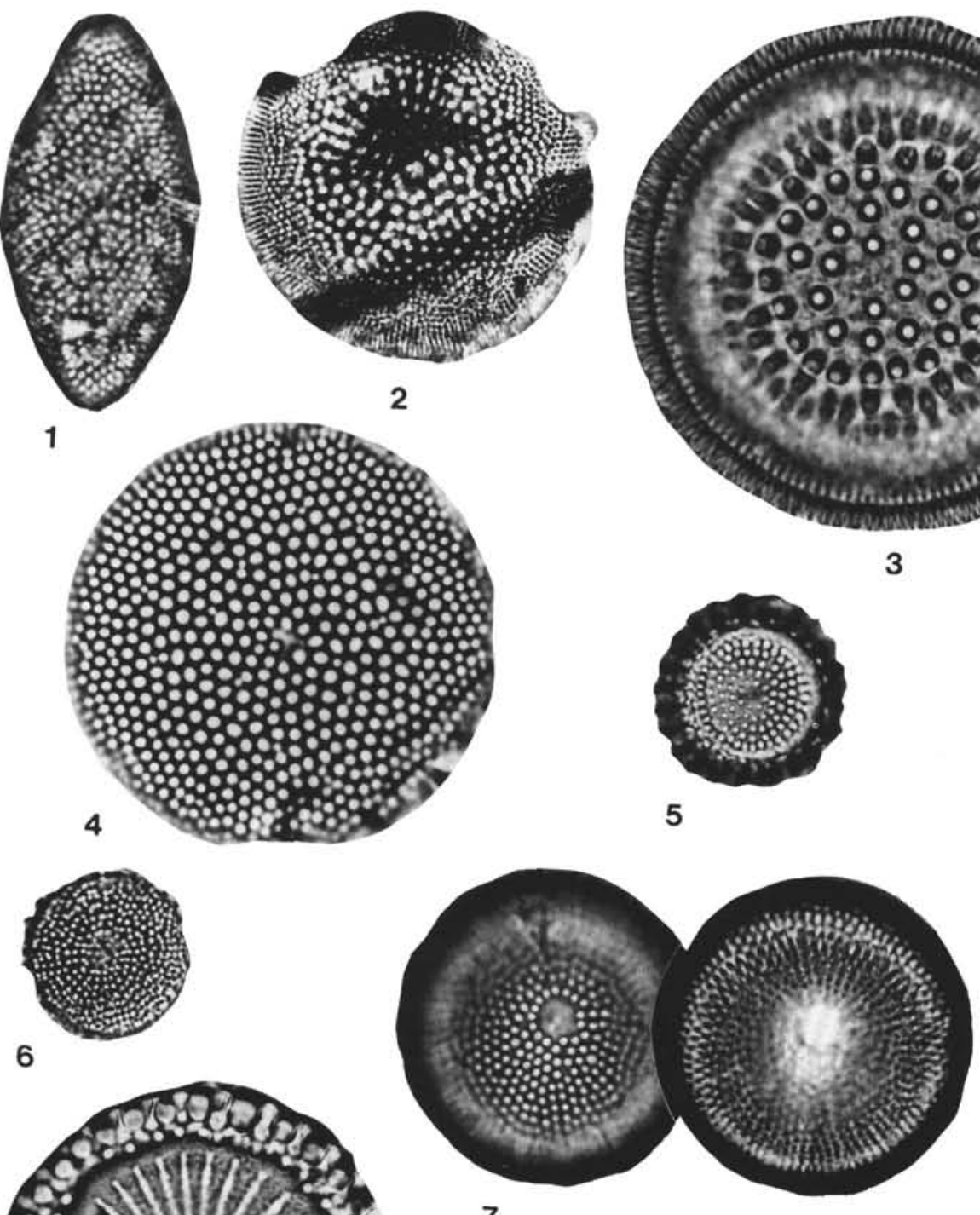

3
7

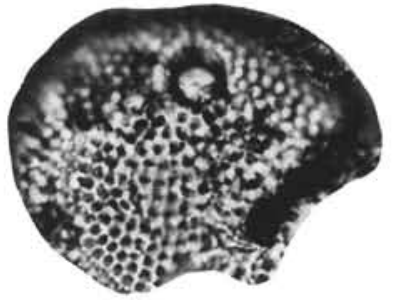

11

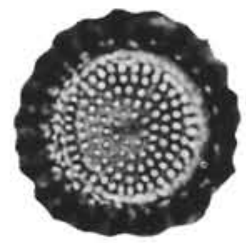

5

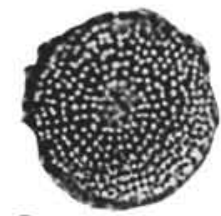

6

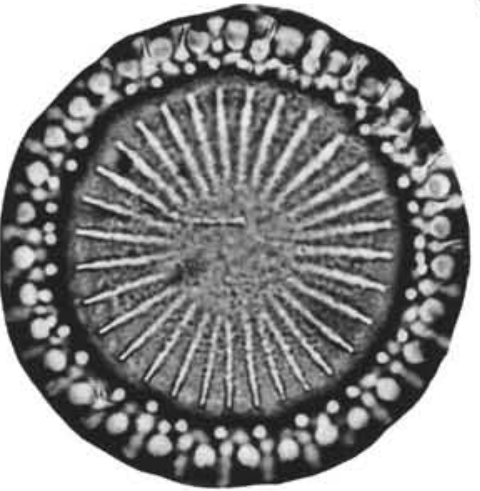

10

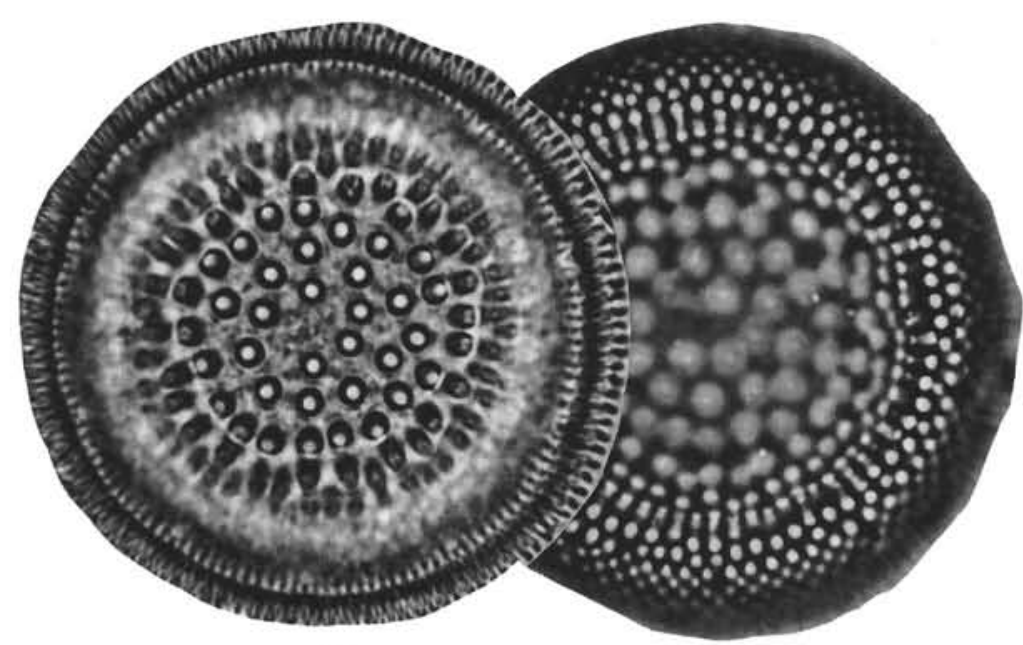

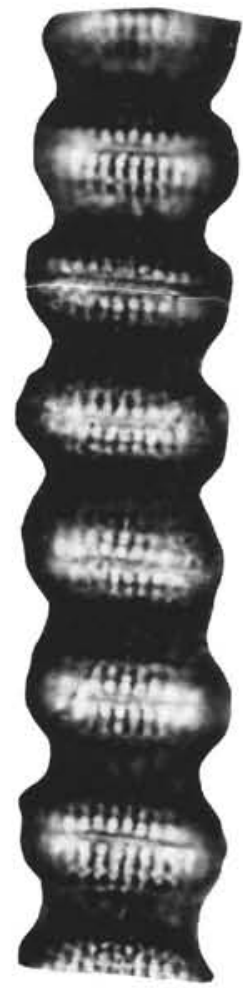

8

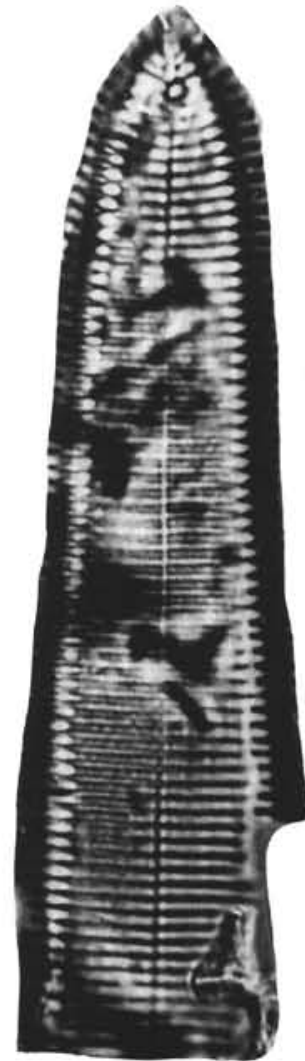

9

Plate 1. Magnification $1500 \times$ if not otherwise indicated. 1. Coscinodiscus(?) sp., Sample 115-711A-16X-CC. 2. Cestodiscus sp., 900 $\times$, Sample 115-714A-22X-CC. 3. Cestodiscus gemmifer, Sample 115-707A-21X-6, 105-106 cm. 4. Thalassiosira bukryi, Sample 115-707A-21X-2, 105$106 \mathrm{~cm}$. 5. Skeletonema barbadense, Sample 115-711A-19X-2, 79-80 cm. 6. Thalassiosira sp., Sample 115-714A-22X-CC. 7. Thalassiosira(?) sp., Sample 115-707A-21X-4, 105-106 cm. 8. Chain of Melosira architecturalis, Sample 115-707A-21X-5, 102-103 cm. 9. Synedra clavata(?), Sample 115-707C-3R-2, 110-111 cm. 10. Paralia sulcata var., Sample 115-707A-23X-2, 105-106 cm. 11. Porodiscus elegans, $900 \times$, Sample 115$711 \mathrm{~A}-19 \mathrm{X}-3,102-103 \mathrm{~cm}$. 

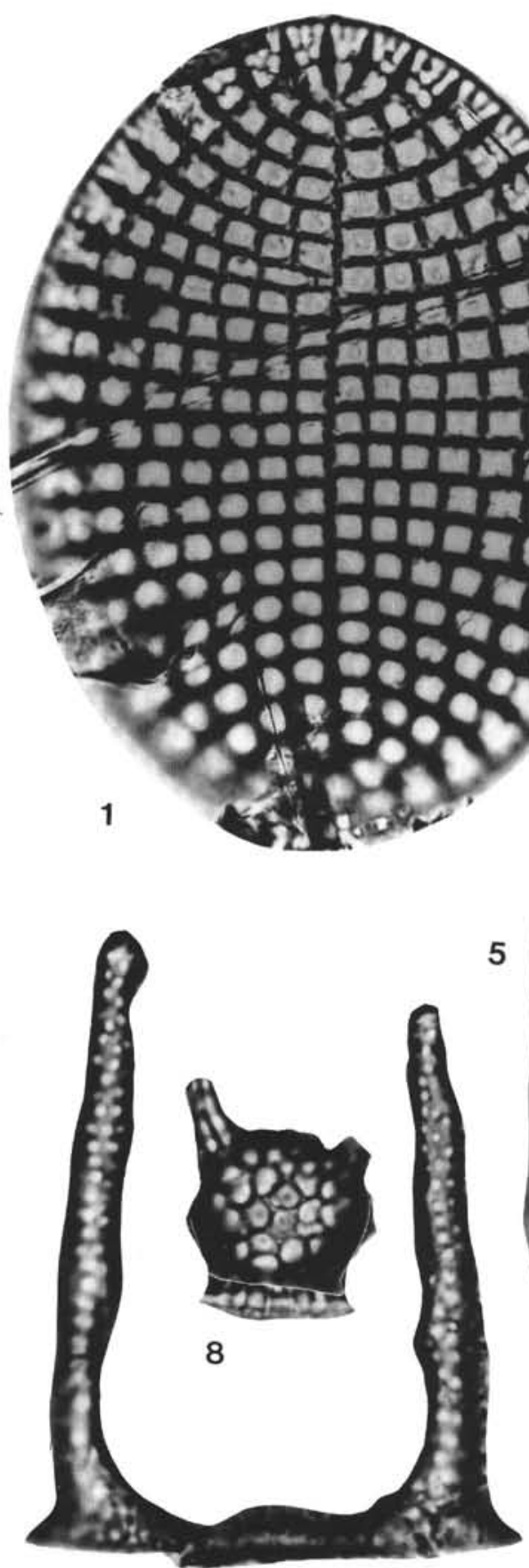

9
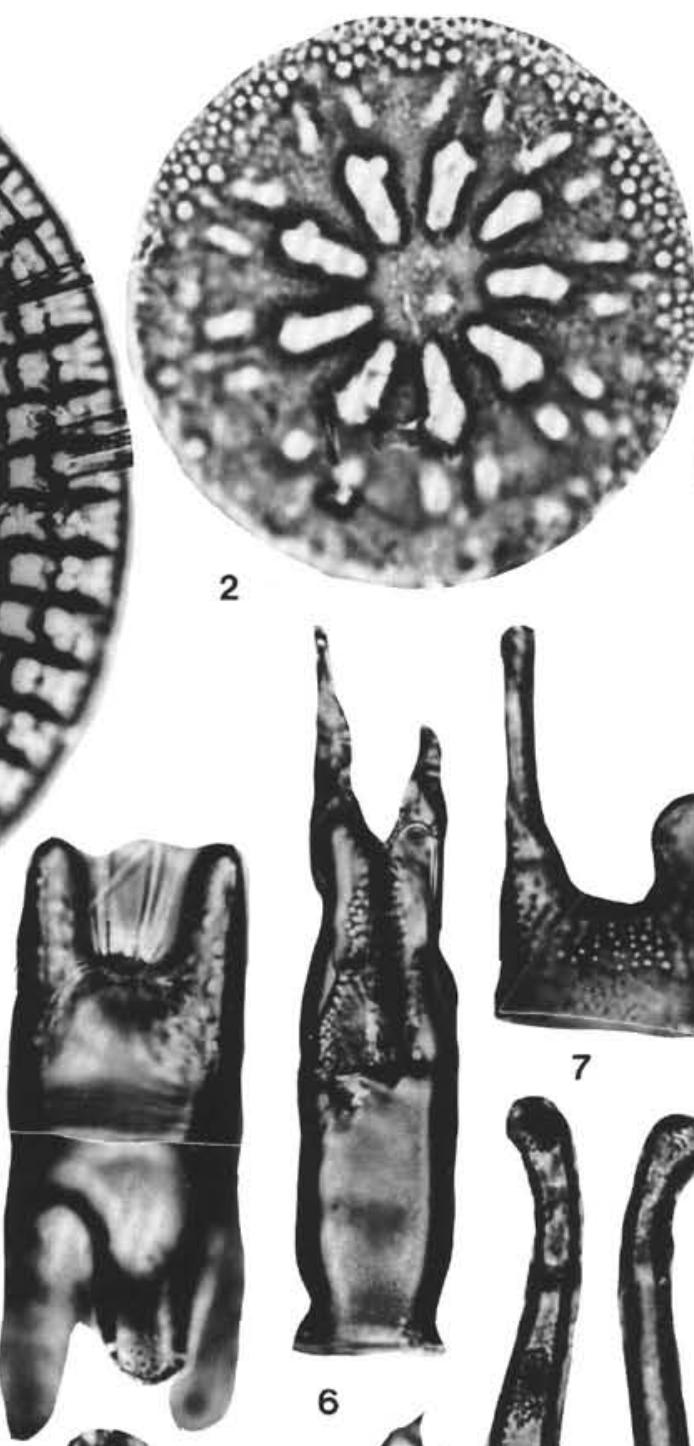

6

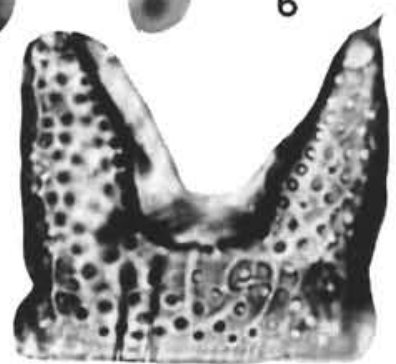

10

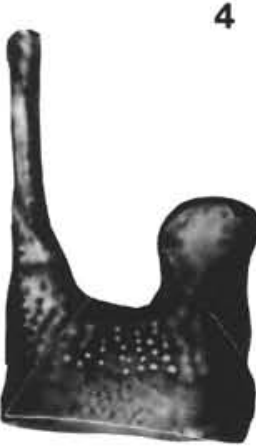

7

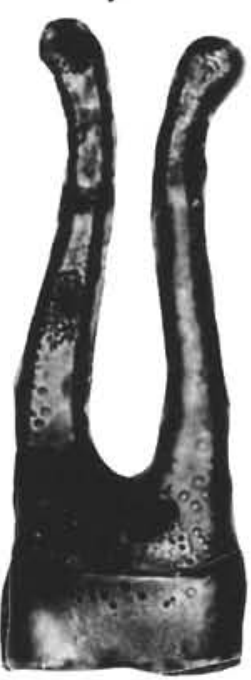

11

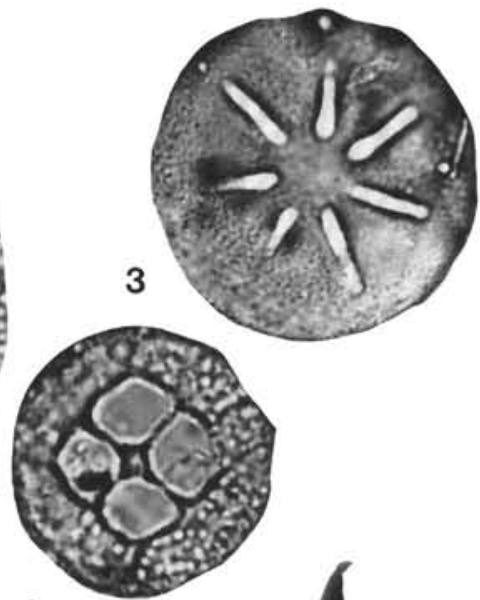

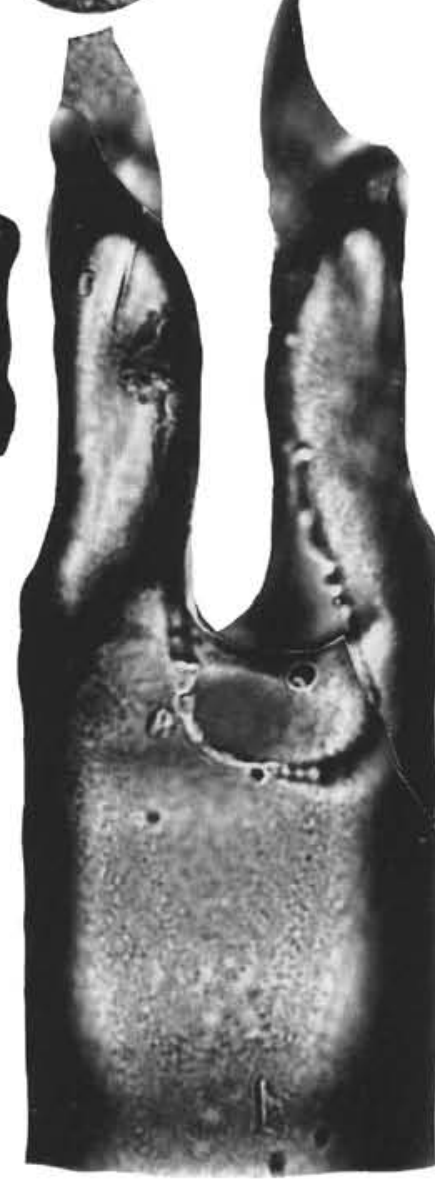

12

Plate 2. Magnification $1500 \times$ if not otherwise indicated. 1. Cocconeis sp., $900 \times$, Sample $115-707 \mathrm{C}-9 \mathrm{R}-2,51-52 \mathrm{~cm}$. 2. Liostephania of Asterolampra vulgaris(?), Sample 115-709C-30R-2, 102-103 cm. 3. Liostephania sp., Sample 115-707A-23X-2, 105-106 cm. 4. Liostephania sp., Sample 115-713A-8R-1, 102-103 cm. 5. Genus et species indet., Sample 115-707A-23X-2, 105-106 cm. 6. Dextradonator eximius, 900 $\times$, Sample 115713A-9R-1, 102-103 cm. 7. Genus et species indet., Sample 115-707A-21X-6, 105-106 cm. 8. Hemiaulus taurus, Sample 115-707A-21X-6, 105$106 \mathrm{~cm}$. 9. Hemiaulus sp., Sample 115-707A-21X-6, 105-106 cm. 10. Hemiaulus subacutus var., Sample 115-711A-18X-1, 103-104 cm. 11. Hemiaulus robustus, $900 \times$, Sample 115-713A-8R-CC. 12. Dextradonator eximius, Sample 115-707C-9R-CC. 


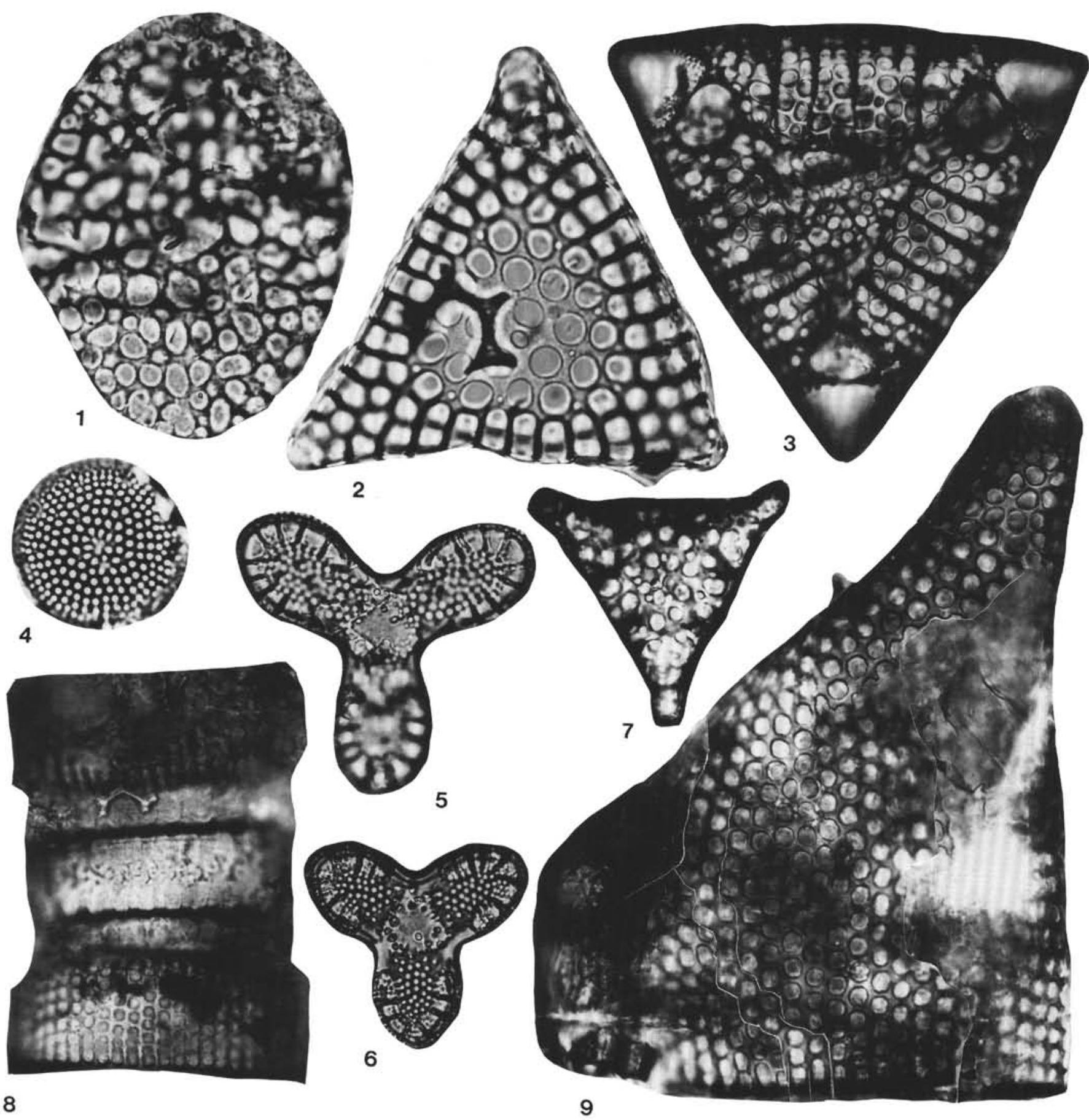

Plate 3. Magnification $1500 \times$ if not otherwise indicated. 1. Genus et species indet., Sample 115-714A-22X-CC. 2. Triceratium aff. americanum, Sample 115-707A-21X-2, 105-106 cm. 3. Entogonia sp., $900 \times$, Sample 115-713A-7R-5, 103-104 cm. 4. Thalassiosira sp., Sample 115707A-21X-2, 105-106 cm. 5-6. Triceratium westianum, 900 X; (5) Sample 115-707C-9R-2, 51-52 cm; (6) Sample 115-713C-9R-1, 102-103 cm. 7. Triceratium aff. brachiatum, Sample 115-708A-25X-1, 102-103 cm. 8. Craspedodiscus umbonatus lateral view, 900 $\times$, Sample 115-713A-7R-3, 103$104 \mathrm{~cm}$. 9. Isthmia sp., $900 \times$, Sample 115-713A-7R-3, 103-104 cm. 

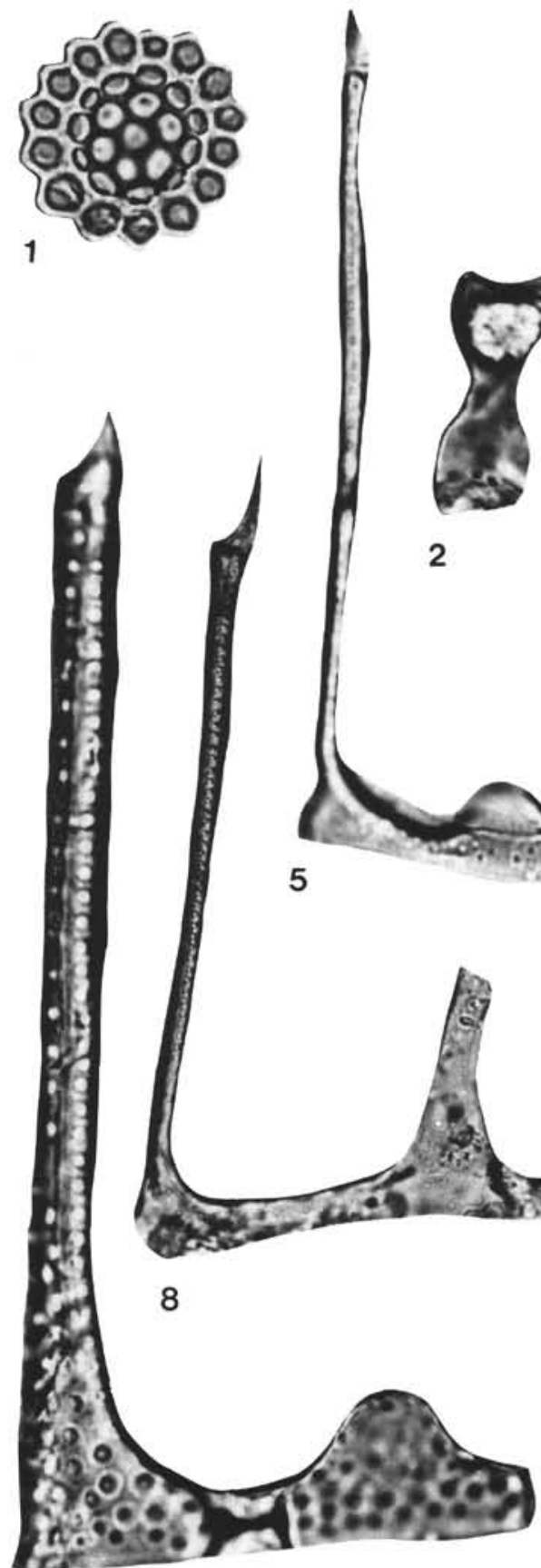

10
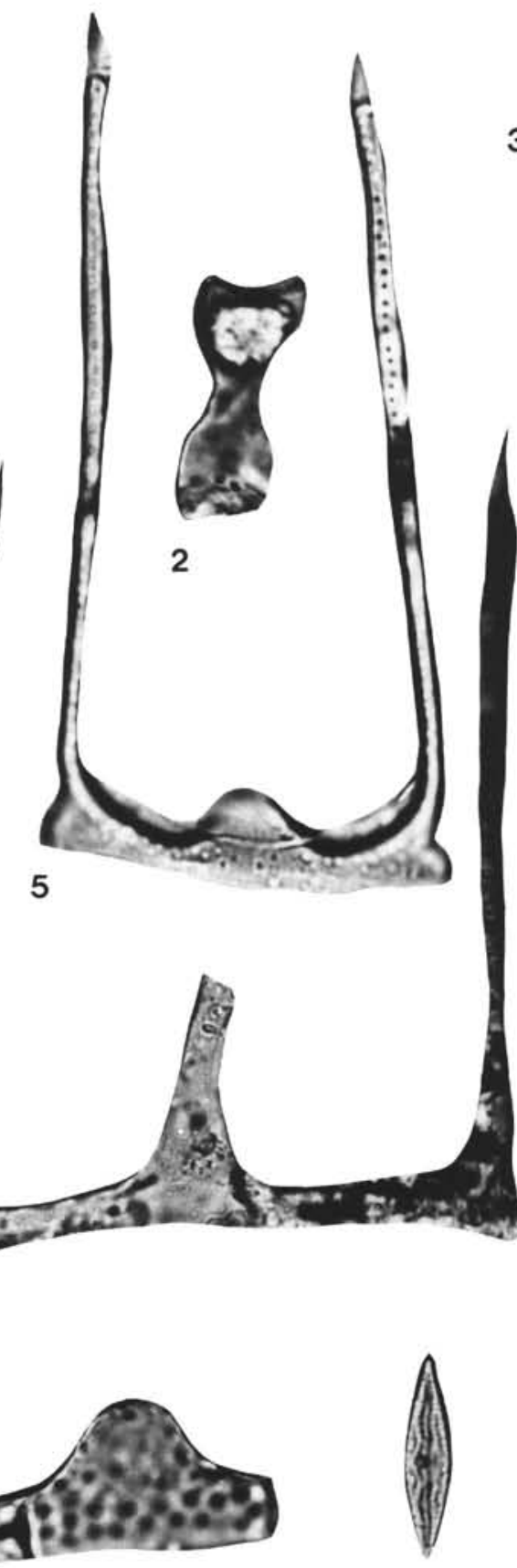

11

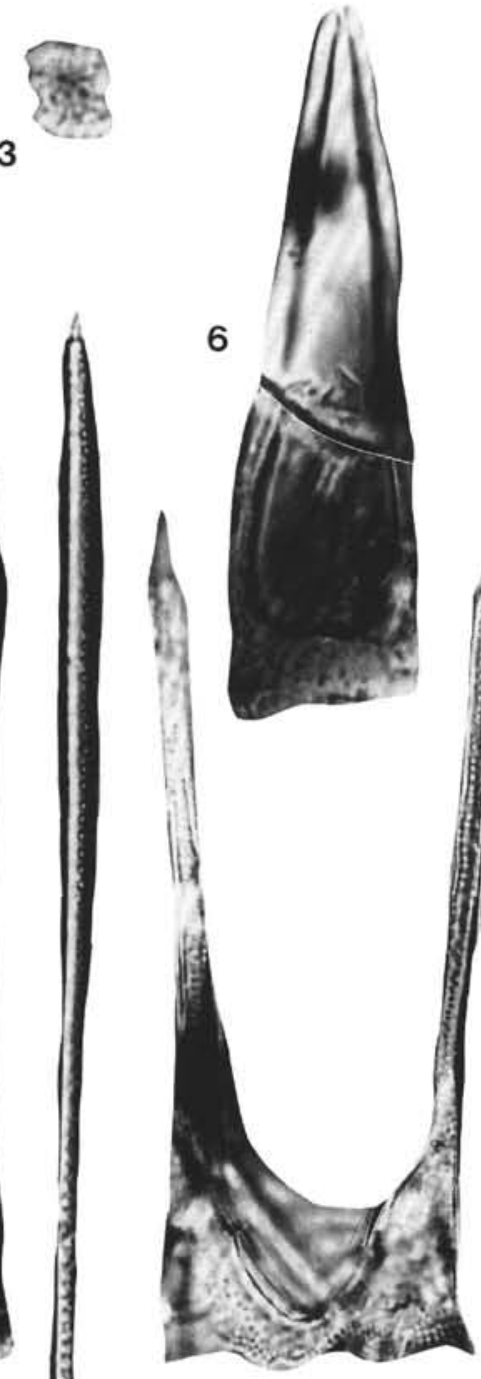

9

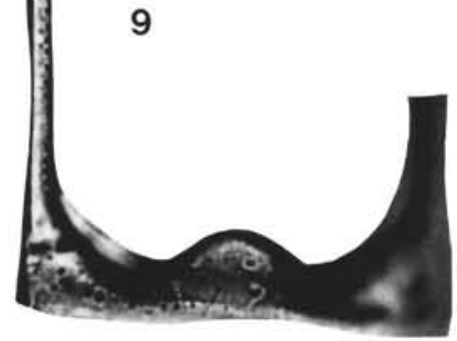

12
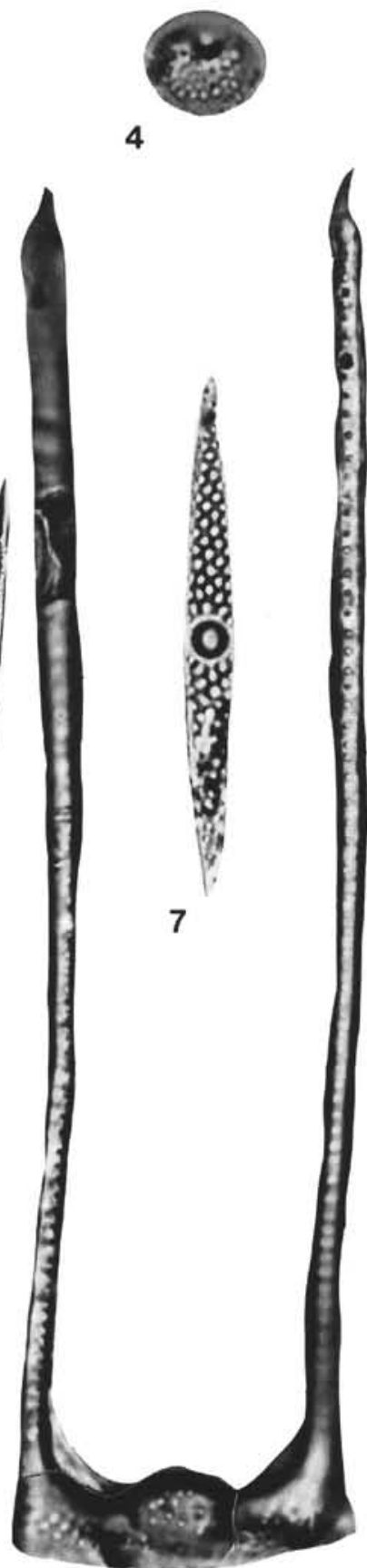

13

Plate 4. Magnification $1500 \times$ if not otherwise indicated. 1. Macrora stella, Sample 115-707C-3R-2, 110-111 cm. 2-3. Phytoliths; (2) Sample 115-707C-3R-6, 110-111 cm; (3) Sample 115-707C-3R-CC. 4. Genus et species indet. (Diatom?, Mallomonas scale?), Sample 115-707A-21X-4, 105$106 \mathrm{~cm}$. 5. Hemiaulus altar, Sample 115-707A-21X-4, 105-106 cm. 6. Hemiaulus claviger, Sample 115-707A-23X-2, 105-106 cm. 7. Rutilariopsis(?) sp., Sample 115-708A-25X-1, 102-103 cm. 8. Hemiaulus altar var., Sample 115-711A-16X-CC. 9. Hemiaulus sp., Sample 115-707A-23X-2, 105-106 cm. 10. Hemiaulus sp. (Sample 115-707A-18H-CC). 11. Navicula(?) sp., Sample 115-707A-22X-6, 105-106 cm. 12-13. Hemiaulus longicornis; (12) $1200 \times$, Sample 115-707A-21X-2, 105-106 cm; (13) Sample 115-709C-29X-2, 102-103 cm. 


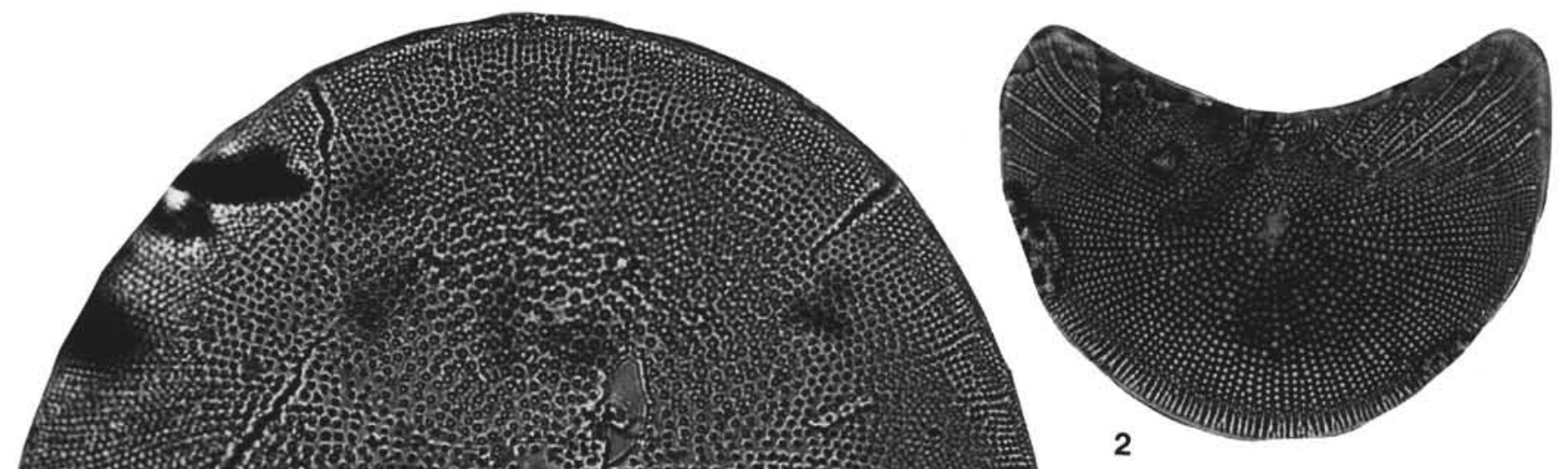

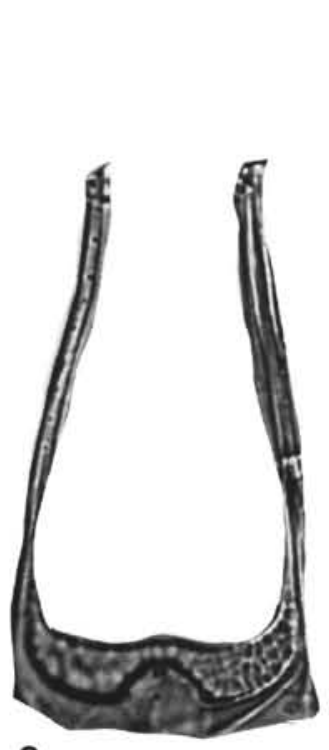

8
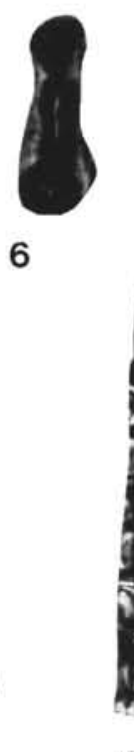

9

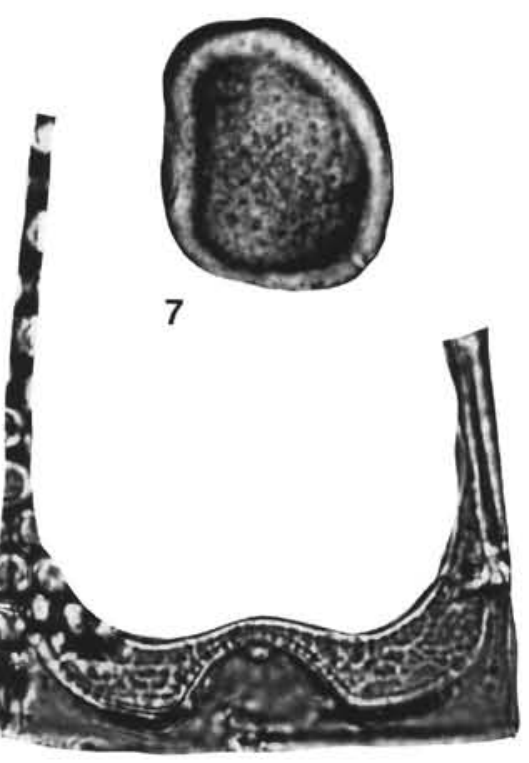

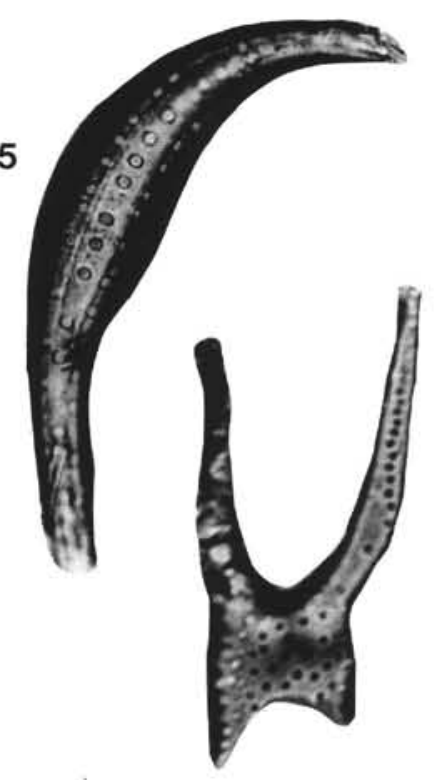

10

Plate 5. Magnification $1500 \times$ if not otherwise indicated. 1-2. Kozloviella meniscosa sp. nov.; (1) Holotype, 850 $\times$, DSDP Sample 366-10-4, 89-90 $\mathrm{cm}$; (2) $660 \times$, DSDP Sample 366-8-4, 41-42 cm. 3-4. Chaetoceros asymmetricus sp. nov.; (3) Holotype, DSDP Sample 369A-22-5, 128-129 cm; (4) Sample 115-707A-21X-6, 105-106 cm. 5. Chaetoceros sp. 2, 900 , Sample 115-707C-3R-CC. 6-7. Spore of mycophyta (fungi)?; (6) lateral view, Sample 115-711A-17X-1, 102-103 cm; (7) Sample 115-707C-3R-2, 110-111 cm. 8-9. Hemiaulus gracilis sp. nov.; (8) Holotype, DSDP Sample 36610-6, 132-133 cm; (9) DSDP Sample 366-9-3, 121-122 cm. 10. Dicladiopsis? sp., Sample 115-707C-3R-6, 110-111 cm. 